NBER WORKING PAPER SERIES

\title{
SEARCH FOR YIELD IN LARGE INTERNATIONAL CORPORATE BONDS: INVESTOR BEHAVIOR AND FIRM RESPONSES
}

\author{
Charles W. Calomiris \\ Mauricio Larrain \\ Sergio L. Schmukler \\ Tomas Williams \\ Working Paper 25979 \\ http://www.nber.org/papers/w25979
NATIONAL BUREAU OF ECONOMIC RESEARCH
1050 Massachusetts Avenue
Cambridge, MA 02138
June 2019

We thank Anil Kashyap, Aart Kraay, Jesse Schreger (discussant), and participants at presentations held at the 2019 ASSA Meetings, Colorado State University, Columbia Business School, George Washington Business School, International Monetary Fund, Sao Paulo School of Economics (FGV), and Stanford University for useful comments. We are grateful to Facundo Abraham, Belinda Chen, Juan Cortina, Marta Guasch Rusiñol, and Soha Ismail for excellent research assistance, and to Tatiana Didier for facilitating access to data. We also thank Zhengyang Jiang and Arvind Krishnamurthy for sharing their data on foreign safe asset demand. The World Bank Chile Research and Development Center, Knowledge for Change Program (KCP), and Strategic Research Program (SRP) provided support for this paper. The views expressed herein are those of the authors and do not necessarily reflect the views of the National Bureau of Economic Research.

NBER working papers are circulated for discussion and comment purposes. They have not been peer-reviewed or been subject to the review by the NBER Board of Directors that accompanies official NBER publications.

(C) 2019 by Charles W. Calomiris, Mauricio Larrain, Sergio L. Schmukler, and Tomas Williams. All rights reserved. Short sections of text, not to exceed two paragraphs, may be quoted without explicit permission provided that full credit, including $(\subseteq)$ notice, is given to the source. 
Search for Yield in Large International Corporate Bonds: Investor Behavior and Firm Responses Charles W. Calomiris, Mauricio Larrain, Sergio L. Schmukler, and Tomas Williams

NBER Working Paper No. 25979

June 2019

JEL No. F21,F23,F32,F36,F65,G11,G15,G31

\begin{abstract}
Emerging market corporations have significantly increased their borrowing in international markets since 2008. We show that this increase was driven by large-denomination bond issuances, most of them with face value of exactly US\$500 million. Large issuances are eligible for inclusion in important international market indexes. These bonds appeal to institutional investors because they are more liquid and facilitate targeting market benchmarks. We find that the rewards of issuing index-eligible bonds rose drastically after 2008. Emerging market firms were able to cut their cost of funds by roughly 100 basis points by issuing bonds with a face value equal to or greater than US\$500 million relative to smaller bonds. Firms contemplating whether to take advantage of this cost saving face a tradeoff: they can benefit from the lower yields associated with large, index-eligible bonds, but they pay the potential cost of having to hoard low-yielding cash assets if their investment opportunities are less than US\$500 million. Because of the post-2008 "size yield discount," many companies issued index-eligible bonds, while substantially increasing their cash holdings. The willingness to issue large bonds and hoard cash was greater for firms in countries with high carry trade opportunities that reduced the cost of holding cash. We present evidence suggesting that these post-2008 behaviors reflected a search for yield by institutional investors into higher-risk securities. These patterns are not apparent in the issuance of investment grade bonds by firms in developed economies.

Charles W. Calomiris

Columbia Business School

3022 Broadway Street, Uris Hall

New York, NY 10027

and NBER

cc374@columbia.edu

Mauricio Larrain

Catholic University of Chile

School of Management

Avenida Vicuña Mackenna 4860

Santiago

Chile

mauriciolarraine@gmail.com

Sergio L. Schmukler

The World Bank

MSN MC3-301

1818 H Street, N.W.

Washington, DC 20433

Sschmukler@worldbank.org

Tomas Williams

George Washington University

Department of Economics

2115 G Street, NW

Room 340

Washington, DC 20052

tomaswilliams@gwu.edu
\end{abstract}




\section{Introduction}

After the 2008 global financial crisis (GFC), interest rates in developed countries reached historically low levels, especially for safe assets. Several studies argue that persistently low interest rates on safe assets have led investors to search for yield by expanding the range of investments they consider and by making them willing to accept increases in risk. As a consequence, the search for yield has expanded the demand for emerging market securities, especially corporate bonds issued in international markets (Becker and Ivashina, 2015; Bruno and Shin, 2017). ${ }^{1}$

Because the international market for debt securities is dominated by institutional investors, who face limits in their incentives or ability to undertake risk in unfamiliar asset classes, the search for yield does not entail an unlimited willingness to accept new risks as the demand for emerging market corporate debt rises. One way to limit risk, while expanding investments into emerging market corporate debt, is to demand liquid instruments. These securities allow investors to more easily sell positions when needed or to increase them when desired, with minimal price impact and low transaction costs. Also, institutional investors are often penalized with withdrawals or rewarded with inflows by the ultimate investors (who are the principals in those investments). This disciplining mechanism encourages managers to think of the risk that affects them (as agents) in terms of deviations from the market benchmark indexes.

By purchasing bonds that are included in major indexes, institutional investors both enhance liquidity and limit the risk of underperforming relevant indexes. ${ }^{2}$ Bonds that

\footnotetext{
${ }^{1}$ We use the phrase "search for yield" to describe either (1) a broadening of the range of investments by institutional investors (e.g., U.S. corporate bond funds) to include riskier (e.g., emerging market corporate) bonds, or (2) decisions by ultimate individual investors to allocate more of their portfolios to riskier investments (e.g., emerging market bond funds).

2 There have been several studies that document that institutional investors such as mutual funds do not deviate too much from their respective indexes. See Cremers and Petajisto (2009) for evidence on the U.S. equity mutual fund industry. Cremers et al. (2016) and Raddatz et al. (2017) show this pattern at the international level. An extreme instance of this strategy is that used by exchange-traded funds (ETFs), the importance of which has increased (Converse et al., 2018).
} 
are included in market indexes are bought and sold more frequently and are held by a wide range of investors, which means that holding a bond that is included in the index enhances its liquidity. Bonds that are included in the index collectively define the benchmark of market performance, which means that holding those bonds limits an institutional investor's risk of underperforming the market benchmark.

Two of the most relevant benchmark indexes for emerging market bonds are the J.P. Morgan EMBI Global Diversified Index (which focuses on sovereign bonds) and the J.P. Morgan CEMBI Narrow Diversified Index (which focuses on corporate bonds). ${ }^{3}$ Both indexes include bonds based on certain security attributes, notably the amount of outstanding debt. Thus, only debt issues with face value equal to or greater than $\$ 500$ (US\$500) million are included in these indexes. A broader index (the CEMBI Broad) also exists, which includes corporate debt with face value equal to or greater than $\$ 300$ million.

Because of their advantages, some institutional investors that expand their holdings of emerging market corporate debt purchase bonds that are included in the major market indexes. This means purchasing large bonds. One would expect that this preference would increase bond prices through an inclusion premium and reduce bond yields, an effect that we label the "size yield discount." Also, one would expect that this preference would increase the likelihood of issuing large bonds, as firms participating in international bond markets take advantage of cheaper financing costs.

In this paper, we analyze how the change in global market conditions after 2008 interacted with market structure to affect the size and pricing of U.S. dollar-denominated bonds issued by emerging market corporations. Specifically, we analyze a period when the low interest rate environment created by developed countries' monetary policies after the GFC interacted with preferences of international investors that follow rules governing the

${ }^{3}$ EMBI stands for Emerging Market Bond Index and CEMBI stands for Corporate Emerging Market Bond Index. 
inclusion of bonds in debt market indexes. We also study how these changes affected firm financing decisions and cash holdings.

Our first novel finding is that the expansion in the demand for emerging market corporate debt was accompanied by an increased preference for bonds large enough to be included in market indexes. After the GFC, we observe a substantial reduction in the yields of bonds issued in international markets with a face value of $\$ 500$ million, relative to otherwise similar bonds with lower face value. For example, when issuing $\$ 500$ million bonds instead of $\$ 400$ million bonds, emerging market corporates paid about 100 basis points less after the GFC than the differential they paid prior to 2008. In other words, the size yield discount increased substantially after 2008. Not only did the average yields of bonds with face value of $\$ 500$ million significantly decrease relative to the period before the GFC, but also this pattern is much more visible for emerging market issuers than for investment grade developed market firms (considered relatively safe investments).

Our second new finding is that, in the post-2008 period, emerging market firms were much more likely to issue debt securities in international markets with a face value of exactly $\$ 500$ million. In general, when deciding to issue a large, index-eligible bond, firms face a trade-off. On the one hand, they can secure cheaper financing costs. On the other hand, if issuance size exceeds financing needs, firms have to save the difference in cash or cash-like instruments, which have low returns. Our second finding suggests that, after the GFC, the increase in the size yield discount moved the trade-off in favor of issuing $\$ 500$ million bonds. Some firms chose to issue more than they needed to fund their projects in order to reach the $\$ 500$ million threshold, and hold cash assets from the proceeds of bond issuance in excess of project funding needs. In addition, we show that higher interest rates earned by firms on their cash assets encouraged them to issue large bonds. We find that firms in countries with higher expected carry trade (our proxy for return on cash) issued 
more $\$ 500$ million bonds, providing further evidence that firms have responded to a tradeoff when deciding to issue large bonds in amounts that exceed their funding needs.

We present suggestive evidence that the channel driving these results is the investor demand for emerging market debt that is skewed towards index-eligible bonds. We show that an increase in the demand for emerging market debt, as proxied by investor flows to emerging market debt funds, is highly positively correlated with the percentage of bond issuances with face value of $\$ 500$ million. Additionally, we show that funds that are less familiar with emerging market corporate debt tend to have the highest demand for indexeligible bonds. For instance, funds that specialize in developed market securities increased their share of investments in emerging markets after the GFC. Also, using portfolio-level data, we show that these funds tend to invest significantly more of their portfolio in bonds with face value equal to or greater than $\$ 500$ million, relative to funds that specialize in emerging market securities.

Although the literature has emphasized the role of the monetary policy environment in shifting the demand for emerging market securities, it is conceivable that factors in emerging markets could also be contributing to aggregate changes in issuance behavior. For example, changes in the willingness of emerging market firms to issue bonds could reflect higher commodity prices that increase the profitability of investment opportunities. The fact that we observe emerging market firms clustering their issuances at exactly $\$ 500$ million after 2008 , however, strongly suggests the importance of bond investor demand-side influences on the change in issuance behavior. It is highly unlikely that new investment opportunities leading to greater needs for funds are clustered exactly at issuance amounts of $\$ 500$ million. Moreover, the fact that yield reductions are discontinuous at the $\$ 500$ million threshold is highly suggestive of bond investor demandside influences. Exogenous increases in firms' desires for more funds in each capital raising activity should lead to higher yields, not the lower ones we observe. 
Next, we examine heterogeneous effects across the firm size distribution. Specifically, we focus on two hypotheses. First, if the change in investor demand for bonds is driving increased issuance, then large firms (defined as those with investment opportunities that are close to or above $\$ 500$ million) should be the firms most likely to take advantage of the cost saving from issuing large bonds after 2008. The reason is that firms with large investment opportunities have more immediate use for funds raised in the bond market. ${ }^{4}$ We find that, in fact, firms with sufficiently small asset size did not issue large bonds either before or after 2008. Second, we expect to find that medium-sized firms (defined more precisely with respect to the size of investment opportunities in the context of our theoretical model) should see the greatest change in the probability of issuing largedenomination debt when its cost decreases. In contrast, the very largest firms might have been issuing large-denomination debt before 2008 simply by virtue of their more significant financing needs, and the very smallest firms saw prohibitive costs from issuing large bonds. We find that, indeed, medium-sized firms did see the largest increase in the probability of issuing large bonds after 2008. These findings are consistent with the view that changes in investor appetite for large bonds, and the consequences of those changes for reducing yields on large bonds, drove the increase in the issuance of large bonds after 2008.

To conclude the empirical analysis, we estimate how firms use issuance proceeds, distinguishing between the behavior of relatively large and small firms that issued large bonds. We show that emerging market firms that issued dollar-denominated bonds in international markets with face value equal to or greater than $\$ 500$ million after 2008 have tended to hold more cash for every dollar of debt issued than firms that issued lesser amounts. This result provides direct evidence of the trade-off faced by firms when issuing

\footnotetext{
${ }^{4}$ In contrast, smaller firms responding to incentives from the investor side will likely have a harder time using large issuance proceeds, implying a cost that should make them less likely than large firms to take advantage of the changes in market conditions that favor large-denomination debt.
} 
large, index-eligible bonds: they can secure lower financing costs, at the expense of hoarding cash. Moreover, the increased holding of cash is greater for small firms that issued large bonds than for large firms that issued large bonds. This is consistent with small firms "stretching" to issue more debt than necessary to fund their investments in order to take advantage of the size yield discount.

Our paper contributes to at least three different literatures. First, by showing that bond index inclusion results in substantially lower yields and changes in issuance choices by firms, we contribute to a large literature analyzing the effects of indexing on securities prices and quantities. This literature has focused mostly on the effects of index rebalancing on the pricing and liquidity of stocks and bonds. ${ }^{5}$ The evidence on the consequences of index investing has been slim (Wurgler, 2011). Our main contribution is to show that the use of indexes by institutional investors has important effects on firms' financial decisions and financing costs. Our evidence provides support for recent theoretical contributions that seek to explain how the use of benchmarks enhances the liquidity of securities (Duffie et al., 2017) and leads asset managers to effectively subsidize investments by benchmark firms (Kashyap et al., 2018). ${ }^{6}$ Our paper extends to the global sphere the evidence that an increase in demand from passive investors increases firms' propensity to issue bonds in the United States (Dathan and Davydenko, 2018). ${ }^{7}$

Second, we contribute to a growing literature studying how the low interest rate environment after the GFC encouraged dollar-denominated corporate bond issuance

\footnotetext{
${ }^{5}$ See, among others, Harris and Gurel (1986), Shleifer (1986), Chen et al. (2004), Barberis et al. (2005), Greenwood (2005), Hau et al. (2010), Claessens and Yafeh (2013), Chang et al. (2015), Raddatz et al. (2017), and Pandolfi and Williams (2019).

${ }^{6}$ The magnitude of our estimates of the reduction in yields of index-eligible bonds is within the same range of the model-implied estimates provided by Kashyap et al. (2018).

${ }^{7}$ Firms in the United States responded to that demand by issuing a disproportionate number of bonds with sufficiently large size just to be eligible to be included in the most relevant indexes. We show that this size effect is present for emerging market debt issuers and that there is a large yield discount for issuing indexeligible bonds. We also show that the increased size-related yield discount for emerging market corporate debt had important consequences for the firm size distribution of corporate debt issuers and for cash holdings, especially by medium-sized firms.
} 
around the world at the expense of other forms of financing, such as bank borrowing. ${ }^{8}$ We show that the search for yield by institutional investors interacted with the institutional arrangements determining index eligibility. The market structure for international debt securities produced a rising incentive for emerging market firms to issue $\$ 500$ million bonds after the GFC. This has important consequences for costs and firms' financing decisions.

Third, our paper is related to the literature analyzing the influences on firms' leverage and cash holdings choices, with particular emphasis on the increase in corporate cash holdings. ${ }^{9}$ For example, Xiao (2018) argues that firms that substitute from bank financing to bond financing increase their holdings of cash for precautionary savings. In this paper we also find that the structure of the corporate bond market can create strong incentives for "over borrowing" by "medium-sized" firms, which end up holding more cash than needed for their investment projects.

The rest of the paper is organized as follows. Section 2 provides a theoretical framework to understand how the search for yield can create a yield discount for indexeligible debt, discussing the consequences for issuers. Section 3 describes our data sources. Section 4 presents our issuance-level results. Section 5 examines bond holding differences among mutual funds with respect to large bonds eligible for inclusion in indexes. Section 6 reports firm-level results that distinguish among the bond-issuance and cash-holding behaviors of firms of different sizes. Section 7 concludes.

\footnotetext{
${ }^{8}$ See among others Adrian et al. (2013), Shin (2013), Becker and Ivashina (2014, 2015), Acharya et al. (2015), Carabin et al. (2015), Feyen et al. (2015), Du and Schreger (2016), Lo Duca et al. (2016), and Cortina et al. (2018) for analyses on the drivers of issuance in corporate debt markets. There has also been a closely related literature studying the behavior of bond funds and how they affect financial conditions for firms (Chui et al., 2014, 2016; Ramos and Garcia, 2015; Goldstein et al., 2017; Shek et al., 2017).

${ }^{9}$ See, for example, Bates et al. (2009), Falato et al. (2013), Begenau and Palazzo (2017), and Bruno and Shin (2017).
} 


\section{Theoretical Framework}

Our theoretical discussion has three parts. First, we review the literature explaining why inclusion in an index can increase the value of a security in the market. Second, we consider why the advantages of inclusion in an index should vary over time for emerging market corporate debt. Third, we apply these theoretical principles to a simple model of index inclusion in the emerging market corporate debt market, where issuance size thresholds are the key determinant of index inclusion.

\subsection{Why Does Index Inclusion Increase Corporate Debt Securities Prices?}

Duffie et al. (2017) show that introducing a market benchmark improves price transparency and promotes trade. Their paper explains how the existence of market benchmarks - defined as “a measure of the 'going price' of a standardized asset at a specified time" - mitigates search friction, which are particularly relevant in over-thecounter markets, such as those for corporate debt. Although their study does not consider the effects of a benchmark on different securities, by construction, the information content of the benchmark should be greatest for those large securities that are components of the benchmark. Thus, the benchmark index reduces search costs and increases liquidity for the included securities that participants are willing to hold and trade.

Kashyap et al. (2018) study more directly how inclusion in an index produces a higher price because asset managers - who are penalized by tracking error - face a strong incentive to hold securities that are included in the benchmark, which they term the "benchmark inclusion subsidy." Furthermore, they show that the higher the risk of the investment, the greater the benchmark inclusion subsidy: the pricing premium for inclusion is an increasing function of the security's riskiness.

In summary, irrespective of whether securities are traded directly by investors or by intermediaries, securities that are included in benchmarks will tend to be more liquid 
and will enjoy a price premium related to liquidity. The presence of institutional investors who care about tracking error adds another pricing premium to securities that are included in the index. This premium, which gives rise to the size yield discount that lowers firms' cost of funds, is an increasing function of risk.

\subsection{Why Does the Size Yield Discount Rise in Response to a Sudden Demand Increase?}

We hypothesize that a surge in investor demand for high-yield dollar-denominated emerging market debt results in a large increase in the proportion of bonds that are managed by asset managers that have relatively little experience with investing in emerging market corporate debt. Some of these managers might enter as new emerging market fund specialists, and will be particularly interested in minimizing tracking error by purchasing index-eligible corporate debt. Others, such as those managing broader portfolios, will find it attractive to purchase index-eligible debt when "crossing over" into the emerging market asset class because of its greater liquidity. The assets of funds investing in broader portfolios tend to be large and managers value the ability to get in and out of positions, especially those that are outside their primary mandate, without having a price impact. ${ }^{10}$

Three frictions in asset management can explain the increase in the fraction of the newly issued debt that is managed by fund managers that lack experience in the emerging market asset class. These are: a human-capital-scarcity friction, a relationship-value friction, and a position-size-limit friction. ${ }^{11}$ The three frictions pertaining to fund managers,

\footnotetext{
${ }^{10}$ Emerging market securities, and especially corporate securities, are a highly specialized asset class. The risks that affect the value of these securities are often quite different from those affecting developed country sovereign or corporate debt (Beim and Calomiris, 2001; Kaminsky and Schmukler, 2008; Karolyi, 2015; Calomiris and Mamaysky, 2019). The risks include internal and external political and geopolitical events. As a response, a specialized group of mutual funds and hedge funds hire and train asset managers to manage portfolios of emerging market securities. This specialized group of managers are skilled at monitoring and managing the constellation of risks that are relevant to this asset class.

${ }^{11}$ First, it is not possible to suddenly increase the supply of trained and experienced emerging market corporate debt asset managers (a human-capital-scarcity friction). Second, preexisting relationships between investors and fund managers tend to encourage investors to place money in the funds they invested in before, which limits the movement of funds to specialized emerging market funds (a relationship-value friction). Third, fund managers cannot manage an unlimited amount of funds effectively, and so preexisting fund
} 
combined with the potential conservatism of new investors, have a clear implication. When low interest rates in developed economies produce a surge in demand for relatively risky emerging market corporate debt, the incremental portfolio position in the new asset class is likely to place more value on securities that are part of the index because of their greater liquidity and lower tracking error. For this reason, the price premium associated with index inclusion should rise. We summarize this implication as:

Hypothesis 1: A sudden increase in demand for emerging market corporate debt should produce a relative increase in the demand for bonds included in global indexes. This should result in an increase in the price (i.e., reduction in the yield) of large, index-eligible debt.

The mechanism behind the reduction in the yield of index-eligible bonds relies on an increase in the funds that are managed by managers who are less experienced in emerging market corporate debt and tend to hold more index-eligible bonds. This leads to the following corollary:

Cross-over Fund Corollary: After the surge in demand for emerging market corporate debt, "crossover" funds (those managing broader portfolios, such as global debt funds) with less experience in emerging market corporate debt will hold a larger proportion of securities that are included in the index than experienced emerging market corporate debt specialists.

\subsection{Implications for Issuers: A Simple Model of Bond Issuance}

Assume a continuum of emerging market firms that are potential bond issuers. Each firm has an investment opportunity of a predetermined scale equal to $X$, where the cumulative distribution function of $X$ is given by $F(X) . X$ represents the size of the firm in the model. Each investment opportunity has the same gross return $R$ and has a positive net present

managers who are experts in the emerging market corporate debt asset class might not be able to take on all the new demand, even if ultimate investors were willing to move funds to specialist managers (a positionsize-limit friction). 
value. Firms finance their investment issuing bonds in foreign currency, so each firm will issue at least the amount $X$. If firms issue more than $X$, they hold the difference between the amount issued and $X$ as cash.

Assume there is a corporate debt index that includes only bonds of face value equal to or greater than 500 (equivalent to $\$ 500$ million in the data). We assume there is a yield discount for index-eligible debt. The interest rate firms pay if they issue $X$ is equal to $Y$ if $X<500$ and equal to $Y^{500}<Y$ if $X \geq 500$. We denote the size yield discount by $D$, where $D=Y-Y^{500}$.

Holding cash is costly because it earns a low return of $Y^{*}<Y-D$. Firms of sufficiently large size $(X \geq 500)$ do not have a choice to make; they simply issue a bond of size $X$ and enjoy the lower financing cost. Other firms $(X<500)$, on the other hand, face a trade-off. They can issue $X$ or "stretch," which implies issuing 500 and holding the remaining $(500-X)$ in cash. Given the cost of holding cash, firms with $X<500$, would never choose to issue amounts of bonds between $X$ and $500 .{ }^{12}$ Profits under each alternative (issuing $X$ or issuing 500) are given by:

$$
\begin{gathered}
\Pi^{X}=X R-X Y \\
\Pi^{500}=X R-500(Y-D)+(500-X) Y^{*} .
\end{gathered}
$$

A firm will decide to issue 500 instead of $X$ if and only if $\Pi^{500}>\Pi^{X}$, which implies: $:^{13}$

$$
\frac{Y}{Y-D}+\frac{Y^{*}(500-X)}{X(Y-D)}>\frac{500}{X}
$$

\footnotetext{
12 The profit of a firm with size $X<500$, issuing $X$, is $\Pi^{X}=X R-X Y$. If that firm issues $X^{\prime} \in(X, 500)$, it obtains profits equal to $\Pi^{X^{\prime}}=X R-X^{\prime} Y+\left(X^{\prime}-X\right) Y^{*}$. We can re-write those profits as: $\Pi^{X^{\prime}}=X R-$ $X Y-X^{\prime} Y+\left(X^{\prime}-X\right) Y^{*}+X Y=\Pi^{X}-\left(X^{\prime}-X\right)\left(Y-Y^{*}\right)$. Given the opportunity cost of cash $\left(Y^{*}<Y\right)$, we get that $\Pi^{X^{\prime}}<\Pi^{X}$, so the firm will never choose to issue $X^{\prime} \in(X, 500)$.

${ }^{13}$ Intuitively, the first two expressions in this inequality capture the benefits to issue 500 (the lower interest rate paid on debt) and the additional revenues from interest on cash holdings. The third term captures the higher debt service cost associated with a larger amount of debt.
} 
This inequality implies a critical value of $X$ above which firms issue 500 in debt:

$$
\hat{X}=\frac{500\left(Y-D-Y^{*}\right)}{\left(Y-Y^{*}\right)}
$$

Let I denote the optimal issuance size. Each firm's optimal issuance size depends on the size of the firm. Thus:

$$
I=\left\{\begin{array}{ccc}
X & \text { if } & X<\hat{X} \\
500 & \text { if } & \hat{X} \leq X<500 \\
X & \text { if } & X \geq 500
\end{array}\right.
$$

Firms in the size interval $[\hat{X}, 500)$, stretch to issue 500 . For these firms, the amount they issue $(I)$ is greater than the amount of their investment opportunity $(X)$. For smaller firms, $(X<\widehat{X)}$, the amount of bond issuance is equal to the size of their investment opportunity. Let $G(I)$ denote the cumulative distribution function of issuance size (i.e., the percentage of issuers that issue the amount I or less):

$$
G(I)=\left\{\begin{array}{llc}
F(I) & \text { if } & X<\hat{X} \\
F(\hat{X}) & \text { if } & \hat{X} \leq X<500 \\
F(I) & \text { if } & X \geq 500
\end{array}\right.
$$

Figure 1, Panel A plots the cumulative distribution of issuance size. The cumulative distribution is flat between $[\hat{X}, 500)$ because no firm issues in this size interval. There is then a discrete jump in the distribution at 500 , driven by the mass of medium-sized firms that find it optimal to stretch and issue 500 .

We model an increase in demand for emerging market corporate debt as an exogenous increase in the size yield discount $D$, in line with Hypothesis 1 . Because $\hat{X}$ is a decreasing function of $D$, the increase in the size yield discount reduces the critical value of asset size above which firms issue 500. Intuitively, as the yield reduction benefit of issuing bonds of 500 increases, firms become more attracted to issue them. This leads to the following hypothesis: 
Hypothesis 2: A sudden increase in demand for emerging market corporate debt should result in an increased propensity to issue debt that is included in the index.

We illustrate Hypothesis 2 in Figure 2, Panel B. The discrete jump of the cumulative distribution at 500 becomes larger, as more firms with values of $X<500$ stretch to issue 500 with the increased size yield discount.

Note that $\hat{X}$ is a decreasing function of $Y^{*}$. The intuition is that a higher return on cash makes the strategy of issuing a bond larger than $X$ and investing the remaining $(500-X)$ in cash more attractive. This comparative static implication derived from Equation (4) - stating that the critical value $\hat{X}$ is lower for higher values of $Y^{*}-$ is summarized in the following hypothesis:

Hypothesis 3: A higher local interest rate should result in a higher propensity to issue large, indexeligible debt.

The model also has several cross-sectional predictions. First, by construction, only firms with scale above $\hat{X}$ find it convenient to stretch and issue a 500 bond:

Hypothesis 4: Large firms are more likely to issue large amounts of debt and, thus, large-denomination bonds that are eligible for inclusion in the index.

In addition, as explained in Hypothesis 2, because an increase in the demand for bonds that are included in the index increases $D$ (reducing their yield), it also reduces $\hat{X}$. A rise in $D$ makes some firms that previously had an investment size $(X)$ that was too small to warrant an issuance of 500 to switch to that type of issuance. This comparative static response to an increase in $D$ is concentrated in "medium-sized" firms (those with investment opportunities in the neighborhood of $\hat{X}$ ). Firms with investment opportunities that are either greater than, or far smaller than, the prior value of $\hat{X}$, should not respond to the increase in $D$ by increasing their bond issuance size. We summarize this comparative static result in Hypothesis 5: 
Hypothesis 5: An increase in the benefit of being included in the emerging market corporate debt index causes some medium-sized firms, which previously would not have issued a sufficient amount of debt to gain inclusion in the index, to issue bonds large enough to gain inclusion in the index. The change in the probability of issuing large bonds should be greater for medium-sized firms than for firms in the upper and lower tails of the size distribution.

Lastly, an increase in the size yield discount $D$ has no effect on the cash holdings of sufficiently large firms, defined as those that would issue 500 or more in debt irrespective of the changes in the yield discount. In contrast, medium-sized firms that prior to the increase in $D$ would have chosen to issue $X$ in debt, respond to the increase in $D$ by choosing to issue 500 in debt, rather than $X<500$, and accumulate cash equal to $(500-X)$. Thus, within the group of firms that choose to issue 500 in bonds, firms of relatively small size will increase their cash holdings more than relatively large issuers of large bonds. We summarize this result in Hypothesis 6:

Hypothesis 6: Within the group of large bond issuers, relatively small-sized firms will increase their cash holdings by more than relatively large-sized firms.

\section{Data}

We use data from different sources. The data on bond issuances come from the Thomson Reuters Security Data Corporation Platinum database (SDC Platinum). This database contains transaction-level information on new issuances of corporate bonds by public and private firms. From this database, we obtain the date a bond is issued, the face value of the bond, and the yield to maturity at issuance. SDC Platinum also contains additional information that we employ, including the rating of the firm at issuance, the country of the firm, the industry of the firm, the market in which the bond is issued, the type of bond (fixed or flexible coupon), the currency of the bond, whether the issuance is public or private, and the maturity at issuance of the bond. 
We focus on issuances of corporate bonds in U.S. dollars, which is a prerequisite to being included in the bond indexes we analyze. We study issuances that take place only in international markets, defined as a firm issuing a bond in a market that is different from its country of origin. Additionally, we compare international dollar-denominated bonds issued by emerging market firms with a sample of investment grade bonds issued by firms from developed markets. In this way, we are able to compare yield and issuance outcomes for firms that are inherently riskier (emerging market firms) with a control group of firms that are considered relatively safe (investment grade developed market firms). This comparison is relevant because we hypothesize that investors' search for yield leads them to increase their exposure to riskier firms around the world. ${ }^{14}$

We include firms from 68 developed and emerging economies (countries or markets) for the period 2000-2016. We use the nationality of the firm that is provided by SDC Platinum to classify firms into developed and emerging markets (as listed in Appendix Table 1). ${ }^{15}$ We include both financial and non-financial firms, because the market structure effects that we document affect issuances by any type of firms. However, our results are robust to excluding financial firms. Our sample includes 19,906 issuances from 4,965 firms.

We complement these data with additional information, mainly from three different sources. We use injections/redemptions to emerging market debt funds from Emerging Market Portfolio Research (EPFR) Global to gauge changes in investor interest in emerging market debt. We use data from Morningstar Direct on the asset level portfolios of mutual funds to understand the different types of investors holding emerging market

\footnotetext{
${ }^{14}$ In the Appendix, we provide additional results using jointly high-yield developed market firm bonds and emerging market firm bonds.

${ }^{15}$ SDC Platinum contains a category that classifies the type of bond issued, which sometimes conflicts with our classification using the nationality of the issuer. If this category indicates that an emerging market firm issues the bond, we classify it as such regardless of the nationality of the firm provided by SDC. This affects only 300 observations ( $1.5 \%$ of our sample).
} 
corporate debt. For the use-of-funds analysis, we merge the SDC data with Worldscope data, which provide information on the financial statements of firms. Those data include important information on firms' assets, cash holdings, and sales (reported in balance sheets, income statements, and cash flow statements). Worldscope data are available for $44 \%$ of the firms in the SDC database, resulting in a merged dataset of 2,190 firms.

\section{Corporate Bond Issuances}

\subsection{New Findings on Yields and Issuance Behavior}

As discussed in Section 2, we conjecture that part of the surge in investor interest in emerging market corporate debt after the GFC reflected a change in the investor base. We hypothesize that this compositional shift, together with the existence of the CEMBI Narrow index, with a $\$ 500$ million minimum cutoff, produced an increase in the interest of international investors for large ( $\$ 500$ million and greater) emerging market corporate bonds.

To study how the shifts in size-dependent investor interest affected market yields, we begin with simple comparisons. In Figure 2, we plot the evolution of the yield to maturity during 2000-2016 for bonds issued by emerging market corporates with face value below $\$ 300$ million, between $\$ 300$ and below $\$ 500$ million, and equal to or above $\$ 500$ million. We observe that yields for all issuance sizes declined after the GFC, but the effect is particularly pronounced for $\$ 500$ million bonds.

In Figure 3, Panel A, we aggregate within the pre- and post-crisis periods and compare the average yield to maturity of bonds of different issuance size for the two time periods. We observe that, on average, yield to maturity decreases with issuance size. More importantly, consistent with Hypothesis 1, after 2008, we observe a sharp decline in the yield when moving to issuance sizes of $\$ 500$ million (a fall of 115 basis points). This decline at the $\$ 500$ million threshold is much more pronounced than that observed in the pre- 
2008 period, suggesting that after 2008 there was an increase in bond investors' demand for bonds of issuance size equal to or greater than $\$ 500$ million. There is also a decline in the yield when moving to the $\$ 300$ million threshold, consistent with the CEMBI Broad having a minimum size requirement for inclusion of $\$ 300$ million. ${ }^{16}$ However, compared to the pre-2008 period, yields for $\$ 500$ million emerging market corporate bonds declined after 2008 by relatively more. ${ }^{17}$

Figure 3, Panel B presents the same analysis as Panel A for investment grade corporate issuers in developed markets. Yields for issuances at the $\$ 500$ million threshold declined after 2008 by about 42 basis points. However, that decline was not much greater than what is observed for the pre-2008 period, 15 basis points, suggesting a much larger relative post-crisis effect on yields for emerging market firms.

Next, we study the implications of the reduction in yields of large, index-eligible bonds on corporate bond issuance behavior. Figure 4 plots the evolution of the total value of U.S. dollar-denominated corporate bonds issued by emerging market firms (Panel A) and the evolution of the total number of issuances (Panel B). The figure shows that the value of international bond issuances by emerging market firms increased sharply after 2008. Between 2008 and 2013, the value of those bond issuances increased by $380 \%$. Consistent with Hypothesis 2, Table 1 also shows that bonds above $\$ 500$ million represented only 33\% of the total value of bonds issued between 2000 and 2008. After 2008, their share of the total nearly doubled to $62 \%$. This is an important new finding:

\footnotetext{
16 The CEMBI Broad includes smaller securities and has a cutoff of $\$ 300$ million. The CEMBI Narrow has an inclusion cutoff of $\$ 500$ million and is composed of more liquid and selected securities. At the end of 2017, \$61 billion tracked the CEMBI Broad, and \$24 billion the CEMBI Narrow. Whereas this could indicate a larger preference toward $\$ 300$ million bonds, the assets tracking the EMBI (with a cutoff of $\$ 500$ million) have been much larger than the assets tracking specifically corporate debt in emerging markets. For a more detailed account of the indexes and requirements for inclusion, see Appendix 1 and Appendix Table 2. ${ }^{17}$ Another notable feature in Figure 3, Panel A is the increase in yields from issuing $\$ 100$ to $\$ 200$ million in the post-2008 period. It is possible that firms that issued $\$ 200$ million were constrained to do so because they could not stretch to issue $\$ 300$ or $\$ 500$ million. Firms that were unable to stretch in the post-2008 period might be indistinguishably riskier than firms that issued $\$ 200$ million in the pre-2008 period, which could explain why yields for $\$ 200$ million issuances remained higher in the post-2008 period.
} 
after 2008, not only did total emerging market corporate bond issuances increased, there was also a dramatic compositional shift from small issuances to large issuances $(\$ 500$ million or more). Similarly, whereas the number of bonds issued above $\$ 500$ million represented $11 \%$ of the total number of bonds between 2000 and 2008, their share increased to 33\% after 2008, as illustrated in Table 1.

To study this compositional change in more detail, Figure 5, Panel A shows the cumulative distribution of emerging corporate bond issuances by size. We plot the distribution for the periods before and after 2008. Firms issue bonds of all sizes, ranging from amounts less than 10 million to nearly a billion dollars. For the post-2008 period, we observe a discrete jump in the distribution at $\$ 500$ million, indicating a new discontinuity in the distribution, with $18 \%$ of all bond issuances having a face value exactly equal to $\$ 500$ million. This discontinuity was much more muted in the pre-2008 period. The empirical cumulative distributions of issuance size resemble the model-based distributions plotted in Figure 1.

The fact that we observe emerging market firms clustering their issuances at exactly $\$ 500$ million after 2008 points to the importance of the investor side. That is, the investor demand for bonds appears to have influenced the change in issuance behavior by firms. We observe a smaller increase for issuances of $\$ 300$ million after 2008 , despite an important decrease in yields in that threshold. One potential explanation is that, because the benefit of reduced yield for issuing $\$ 500$ million bonds is much larger than for issuing $\$ 300$ million bonds, many firms decided to issue the former rather than the latter.

Figure 5, Panel B replicates the previous figure, but for the sample of investment grade firms issuing dollar-denominated bonds in developed economies. For those issuers, we observe a smaller jump in the distribution at $\$ 500$ million, and one that is more similar before and after 2008. This is consistent with low-risk, advanced economy firms with lower bond yields responding less to the post-2008 search-for-yield phenomenon. The difference 
between corporates across the two types of countries suggests that changes in the investor side during the post-GFC environment was much more relevant for emerging market corporate bond issuers than for developed country investment grade issuers. ${ }^{18}$

Table 2 reports the statistical significance of the differences in means for yields and issuances, before and after 2008, for emerging economy issuers and investment grade developed market issuers. Panel A shows that yields fell after 2008 for both bonds with face value in the [400:500) range and those in the [500:600) range (expressed in millions of U.S. dollars). But they fell much more for emerging market issuances in the [500:600) range. The triple difference test is statistically significant and shows a differential of almost 100 basis points in the decline in yields between emerging and developed markets. The table shows analogous comparisons in the issuance activity (Panel B), which reacted positively to the yield decrease, again especially in emerging markets in the [500:600) range. ${ }^{19}$

\subsection{Regression Analysis}

We next use regressions to estimate how yields and issuances of bonds of different issuance size categories changed after 2008 for emerging market firms. These regressions allow us to control for observable and unobservable characteristics that can predict yields and issuance size. As before, we include both emerging market issuers and investment grade developed market issuers in our analysis. We estimate the following type of regression for bond yields:

\footnotetext{
${ }^{18}$ Results for high-yield developed country issuers' yields and issuances are very similar to those for emerging market firms (Appendix Figure 2). These two sets of firms share two important characteristics. First, they are inherently riskier than investment grade developed market firms. Furthermore, these high-yield developed economy firms also can be included in special indexes that are similar to the CEMBI and EMBI. The Bloomberg Barclays High Yield Very Liquid Index is an important benchmark for these firms that only includes high-yield dollar-denominated debt from developed market firms, with a minimum issue size of $\$ 500$ million.

${ }^{19}$ Appendix Table 3 reports similar results using narrower bins.
} 


$$
\begin{aligned}
\text { Yield }_{i t}= & \sum_{X=100,200, \ldots, 900}\left(\beta_{X}^{D M} * D_{[X: X+100)_{i t}}+\beta_{X}^{D M, P o s t} * D_{[X: X+100)_{i t}}\right. \\
& * \text { Post }+\beta_{X}^{E M} * D_{[X: X+100)_{i t}} * D_{E M}+\beta_{X}^{E M, P o s t} * D_{[X: X+100)_{i t}} \\
& \left.* \text { Post } * D_{E M}\right)+\theta_{c}+\theta_{j}+\theta_{q y}+Z_{i t}+\varepsilon_{i t} .
\end{aligned}
$$

In this specification, Yield $_{i t}$ is the yield to maturity of a bond issued by firm $i$ in time $t$, where $t$ can be any given day during our sample period. $D_{[X: X+100)_{i t}}$ is a dummy variable that indicates if the bond issued is of size $[X: X+100)$, where $X=$ $100,200, \ldots, 900$ million U.S. dollars (there are no bond issuances with face value greater than $\$ 1,000$ million in the data). $D_{E M}$ is a dummy variable that indicates whether a firm belongs to the emerging market category. Post is a dummy variable that denotes bonds issued in the post-2008 period. $\theta_{c}, \theta_{j}$, and $\theta_{q y}$ are country, industry, and quarter-year fixed effects. $Z_{i t}$ is a vector of bond controls, including whether a bond is issued in public or private markets, whether the issuer is foreign owned, whether the government owns the firm (at least partially), and whether the bond coupon rate is fixed or flexible. The regressions also control for the maturity and rating of the bonds. We cluster the standard errors in all regressions by country and quarter-year.

The regressions estimate how the yield has changed in the post-2008 period relative to the pre-2008 period for a bond of size $[X: X+100)$ that was issued by an emerging market firm relative to one issued by an investment grade developed market firm. More specifically, we estimate (controlling for unobservables) the change in the size yield discount from the pre-2008 period to the post-2008 period for emerging markets relative to developed markets. This differential is captured by $\beta_{500}^{E M, P o s t}-\beta_{400}^{E M, P o s t}$.

In our issuance regressions, we use the following specification:

$$
\text { Issuance }_{[X: X+100)_{i t}}=\theta_{c}+\theta_{j}+\theta_{t}+\beta * \text { Post } * D_{E M}+Z_{i t}+\varepsilon_{i, t} \text {, }
$$


where the dependent variable is a dummy variable that indicates whether bond $i$, issued at time $t$ is of size $[X: X+100)$, where $X=100,200, \ldots, 900 .^{20}$

Equations (7) and (8) are effectively difference-in-difference specifications, where we use developed economy investment grade firms as a counterfactual for the behavior of emerging market firms. We are interested in the coefficient of the interaction term, $\beta_{X}^{E M, P o s t}$ in Equation (7) and $\beta$ in Equation (8). They measure either the change in the yield to maturity of a certain size or the change in the probability of issuing a bond of a certain size, before and after 2008, for emerging market firms relative to the same change for developed economy firms.

To test for pre-treatment parallel trends, in Figure 6, Panel A displays the evolution of the average yield to maturity over the period 2000 to 2016 for $\$ 500$ million bond issuances by emerging market issuers and developed market investment grade issuers, respectively. Panel B shows the evolution of the average number of bond issuances of size equal to $\$ 500$ million, relative to the total number of issuances, for the same two sets of issuers over the same period. Until 2008, we observe a similar pattern in yields and issuances for the two groups. After 2008, we observe a sharp decline in the yields of $\$ 500$ million issuances and an increase in the number of $\$ 500$ million issuances only for emerging market bond issuers.

We report the results of estimating Equation (7) in Table 3. To make the table more readable, we report only the coefficients for $\beta_{X}^{E M, P o s t}$ in the table. ${ }^{21}$ We compare the

\footnotetext{
${ }^{20}$ In Appendix Table 4, we show that our results are robust to adding firm fixed effects. The specification with firm fixed effects is more stringent than the regression with industry fixed effects, because it allows us to control for unobserved time-invariant firm characteristics. However, to identify firm fixed effects, we need to restrict our sample to firms that have issued at least two bonds, one in the pre-2008 period and another in the post-2008 period, forcing us to lose many observations.

${ }^{21}$ In Appendix Table 5 and 6, we report all the estimated coefficients. With those coefficients we can compute the reduction in yields from issuing $\$ 500$ million rather than $\$ 400$ million bonds within a country group, between the post-2008 and pre-2008 periods. For developed market firms, this double differential ranges from 3 to 22 basis points, depending on the controls used, and is not statistically different from zero. For emerging market firms, it ranges from 93 to 218 basis points and is statistically different from zero.
} 
size yield discount for emerging market issuers after 2008 with the size yield discount for developed economy investment grade issuers after 2008, taken relative to the pre-2008 values. We find that this triple differential, $\left(\beta_{500}^{E M, P o s t}-\beta_{400}^{E M, P o s t}\right)$, is 99 basis points, which is statistically different from zero. This size yield discount difference falls to 92 basis points when we add country, industry-year, and quarter-year fixed effects (Table 3, column 2). When we add bond controls, maturity, and ratings fixed effects, the size yield discount difference becomes 76 basis points and remains statistically different from zero (Table3, column 3). Results are very similar when we use spreads over the maturity-relevant U.S. treasuries, rather than yields, as the dependent variable.

With respect to issuance quantities, we estimate Equation (8) using the issuance indicator for bonds in different size bins as the dependent variable. ${ }^{22}$ Table 4, Panel A shows that the coefficient of the interaction term is positive and statistically significant for issuances of size between $\$ 500$ and $\$ 600$ million. This means that after 2008 emerging market bond issuers were 9 percentage points more likely to issue bonds in this size bin, relative to developed economy investment grade issuers. This is a significant effect, especially when compared to the average probability of an emerging market firm issuing a bond of $\$ 500$ million before 2008 , which is $10 \%$. At the same time, the likelihood of issuing bonds in the [100:200) bin decreased, as emerging market issuers substituted large bond issues for small ones. The issuance of $\$ 300$ to $\$ 400$ million bonds also increased after 2008 , but by less than for the $\$ 500$, consistent with our finding that the decrease in the yields for

\footnotetext{
${ }^{22}$ In additional robustness tests we also include maturity-time and ratings-time fixed effects and results remain very similar (Appendix Table 7).
} 
this size group was smaller. As before, results are very similar when we control for bond characteristics (Panel B). ${ }^{23,24}$

\subsection{Placebo Test of Bond Index Inclusion}

To provide a placebo test of whether our results are driven by the index inclusion requirements, we re-estimate Equations (7) and (8) using bonds that are not included in the CEMBI index because of other index-inclusion requirements unrelated to size. Specifically, we keep only floating rate bonds and bonds with less than five years of maturity. Because these bonds are not included in the index, irrespective of size, we expect to find no effects on issuances and yields at the $\$ 500$ million threshold. Table 3 , column 4 reports the results of this exercise for yields and Table 5 reports the results for issuances. Indeed, we observe no significant change in the yields of bonds in the bin size [500:600) and no significant increase in issuances for these bonds. This test supports the hypothesis that the decrease in yields and the increase in issuances after 2008 for bonds of size between $\$ 500$ and $\$ 600$ million reflect the effect of index inclusion, not size per se.

\subsection{Carry Trade Influences}

Our theoretical framework in Section 2 also predicts that, ceteris paribus, firms should be more likely to issue $\$ 500$ million bonds when they are located in countries where there is a relatively large expected local interest rate from investing in cash (Hypothesis 3). In Table 6 , we test that prediction by exploiting the cross-country variation in our sample. We regress a dummy that is one if a firm issued a $\$ 500$ million bond and zero if the firm issued

\footnotetext{
${ }^{23}$ We also test whether the treatment effect of index inclusion interacts with the Treasury basis variable constructed by Jiang et al. $(2018,2019)$, which they interpret as a convenience yield for U.S. Treasuries. Most of the variation in that variable occurs during the 2007-2009 crisis. We find that there is no evidence of an interaction after the crisis (Appendix Table 8).

${ }^{24}$ Table 4 estimates Equation (6) for a sample of strictly positive issuance observations. In Appendix Table 9 , we re-estimate the equation for a sample containing all observations (including those with no issuances) and the results remain unchanged.
} 
any bond below that size on our carry trade variable. Following Bruno and Shin (2017), our measure of carry takes the form of a "carry Sharpe ratio," which is the difference between the local money market interest rate and the U.S. money market interest rate. We adjust for exchange rate risk by dividing the interest rate differential by the annualized volatility of the exchange rate during the previous two quarters. Like a Sharpe ratio, this measure captures the expected profit from investing in local currency adjusted by exchange rate risk. We include time fixed effects to exploit the cross-country variation, along with different sets of fixed effects and bond controls. We find that there is a positive and statistically significant association between the carry trade measure and the probability of issuing $\$ 500$ million bonds. Interestingly, in results not reported here, we find no statistically significant carry effect when we do not adjust for the volatility of the exchange rate. This suggests that firms do take the risk of exchange rate depreciation into account when deciding to issue dollar-denominated bonds.

\section{Inspecting the Mechanism: The Role of Institutional Investors}

We posit that the driver of change in the importance of index eligibility over time is the movement to a low interest rate environment in developed economies. The search for yield across the world and the increase in investor interest in emerging market corporates raised the value to fund investors of holding large emerging market bonds that are part of indexes.

We also conjecture that the composition of international investors changed from a near exclusive reliance on a preexisting group of specialist emerging market corporate bond investors toward a broader investor base. The latter includes old and new emerging market sovereign bond funds and developed economy corporate bond funds, managed by agents with relatively little prior experience in the emerging market corporate asset class. We label these developed market institutional investors and emerging market sovereign 
investors the "cross-over investors," because they are crossing over from other asset classes into the emerging market corporate debt asset class. In the cross-over corollary in Section 2, we hypothesize that these cross-over investors will tend to invest more in indexeligible bonds relative to specialists.

In this section, we explicitly test the cross-over corollary, using data on different funds' holdings of emerging market corporate bonds. Figure 7 presents two pieces of evidence that connect investor interest with changes in the composition of emerging market corporate bond issuance. Panel A plots the cumulative flows into mutual funds that invest in emerging market sovereign and corporate debt from 2003 to 2016. It also plots the number of $\$ 500$ million bonds issued by emerging market firms, as a fraction of all bonds issued by these firms. The correlation between the two is very high (0.93), showing a clear connection between the growing investor interest in emerging market debt and the growing relative importance of issuances that just meet the threshold of $\$ 500$ million. Panel B plots the percentage of the portfolio invested in emerging markets by developed market debt mutual funds from 2005 to 2016. We observe a sharp increase in the weight dedicated to emerging market securities within these funds, which is consistent with a crossing-over of developed market debt funds into emerging market securities. Together, these figures show the increase of investor interest in emerging market debt securities, from ultimate investors and from asset managers from developed countries.

We complement the evidence in Figure 7 with additional evidence showing that investors less familiar with the emerging market corporate asset class tend to hold a greater proportion of index-eligible emerging market corporate debt. We assemble data from Morningstar Direct on debt funds that we categorize into emerging market corporate specialists and cross-overs, using fund categories provided by Morningstar. Within the cross-over category, we also classify funds into emerging market mixed (those that invest in both emerging market corporate debt and sovereign debt), emerging market sovereign, 
and developed markets (Appendix 2). Our data contain 1,435 funds with $\$ 4,561$ billion in assets under management (Table 7).

Funds that specialize in emerging market corporate debt are relatively small compared to funds that specialize in sovereign emerging market debt or developed market funds. For each of the funds, we observe its portfolio at the end of December 2016. Most of the funds in each category held at least one emerging market corporate bond in their portfolio. Within each category, emerging market corporate debt constituted 2\%, 16\%, $19 \%$, and $64 \%$ of the debt portfolios of developed market, emerging market sovereign, emerging market mixed, and emerging market corporate specialists funds, respectively.

One more noteworthy feature is the importance of each type of fund in terms of their investments in the dollar-denominated emerging market international corporate debt market. ${ }^{25}$ Cross-over funds together invested $\$ 128.4$ billion in emerging market corporate bonds, while emerging market corporate specialists invested $\$ 20.8$ billion in these securities at the end of 2016 (Table 7, column 7). Although advanced market funds held a low fraction of emerging market securities in their portfolios, the fact that the sizes of those funds tend to be so large implies that they held a substantial dollar amount in emerging market debt. These data show the importance of cross-over investors for this market.

We test the cross-over corollary in Table 8. For each type of fund, we first compute the total amount of U.S. dollar-denominated corporate emerging market bonds (issued in international markets) held in the portfolio. Then, we compute the percentage of that amount held in each of the following three categories: bonds with face value less than $\$ 300$ million, bonds with face value in the $\$ 300$ - $\$ 500$ million range and bonds with face value equal to or greater than $\$ 500$ million. We compute the average percentage held in each specific bucket size by each mutual fund category. We compare across funds of different

\footnotetext{
${ }^{25}$ Most of the funds in our sample invest only in dollar-denominated emerging market corporate bonds issued in international markets. In 2016, these bonds represented $85 \%$ of their holdings in emerging market corporate bonds.
} 
categories, and with respect to the outstanding amount of corporate bonds issued by emerging market firms.

The results lend support to the cross-over corollary. Cross-over funds invest relatively more in bonds with face value equal to or greater than $\$ 500$ million. In fact, we obtain a consistent fund pecking order with $83 \%, 78 \%, 74 \%$, and $69 \%$ invested in this bucket size by developed market, emerging market sovereign, emerging market mixed, and emerging market corporate specialists funds, respectively. We report differences in means tests for each type of cross-over fund relative to the corporate emerging market funds (Table 8, column 4). We find that sovereign emerging market and advanced market funds display statistically significant differences with respect to the holdings of corporate emerging market bonds. Additionally, we compare the portfolio of each type of fund with the total amount outstanding of dollar-denominated international corporate emerging market bonds at the end of 2016 (Table 8, column 5). In general, corporate emerging market funds held a portfolio similar to the outstanding amount of corporate bonds, whereas cross-over funds skewed their portfolio toward large-denomination bonds.

\section{Consequences for Firms}

Our analysis of yields and issuances in Section 4 is highly suggestive that a shift in bond investor demand (search for yield) has been the main driver of the post-2008 yield decline and issuance increase for large emerging market corporate bonds. However, that evidence does not rule out some potential influences from the issuer side - such as improvements in investment opportunities - in driving some of the increase in large-face value emerging market corporate bond issuances.

In this section, we consider how firm-level differences could affect issuance behavior. This analysis provides additional evidence that sheds more light on the role of bond investor demand changes in driving our results. The evidence is reported in two 
parts. First, we test the two implications about bond demand shifts for cross-sectional differences in issuer responses (Hypotheses 4 and 5), both of which follow from the fact that different sized firms face different economic costs when issuing large amounts in the bond market. Second, we examine the uses of funds raised by firms of different sizes that issue large bonds (Hypothesis 6) as part of our firm-level analysis. In theory, firm size should be measured with respect to the size of a firm's investment opportunity. In practice, investment opportunity size is not observable, so we use asset size as a proxy, assuming a positive correlation between the two. Medium-sized firms are defined, in theory, as those with investment opportunities just below the pre-2008 critical value $\hat{X}$. We have no theoretical prior to predict the corresponding asset size of medium-sized firms in the firm size distribution. In our empirical work, we identify medium-sized firms as those occupying the range of the asset size distribution between small firms (which are too small to respond to the post-2008 increase in the yield discount for $\$ 500$ million bonds) and large firms (which are so large that they issued bonds equal to or greater than $\$ 500$ million before and after 2008). ${ }^{26}$

\subsection{Bond Issuance Differences and Firm Size}

Figure 8 tests a firm-size related implication of the post-GFC investor demand-side shift: medium-sized firms should display the biggest change in their propensity to issue large, index-eligible bonds (Hypothesis 5). Prior to 2008, medium-sized firms should have been less likely than large firms to issue large bonds, but unlike small firms, medium-sized firms (those willing to accumulate excess cash balances to access low-interest funding) decided to stretch and issue $\$ 500$ million bonds after the GFC. Figure 8 is consistent with this

\footnotetext{
${ }^{26}$ Firms likely differ in the ratio of asset size relative to investment opportunity size. In our empirical work, therefore, we do not expect to identify a single threshold value of assets that corresponds to a fixed proportion of the theoretical threshold value of medium-sized firms' investment opportunities. Rather, we expect to find that the responsiveness of firms to the increase in the post-2008 yield discount on large bonds should be zero for very small asset size, then rise as asset size increases, and decline at very large asset size.
} 
prediction: the size distribution of firms issuing bonds of $\$ 500$ million or more shifted to the left after 2008 .

In addition, we conduct Probit and Logit estimations, separately for emerging market issuers and developed market investment grade issuers, to estimate how firm size affects the change in the probability of issuing a large bond (equal to or greater than $\$ 500$ million) after the GFC. We estimate:

$$
D_{i, t}=\beta_{1} \text { Pre }+\beta_{2} \text { Post }+\beta_{3}\left(\text { Pre } * \text { Size }_{i t}\right)+\beta_{4}\left(\text { Post } * \text { Size }_{i t}\right)+\varepsilon_{i, t} \text {, }
$$

where $D_{i, t}$ is a dummy variable equal to one if a firm issued a bond with face value equal to or greater than $\$ 500$ million, and zero if it issued a bond of smaller size. We measure the size of a firm with the log of total assets.

Table 9, Panel A shows that both interaction terms $\left(\beta_{3}\right.$ and $\left.\beta_{4}\right)$ are positive and highly significant. This indicates that larger firms were more likely to issue larger bonds than smaller firms, both before and after the GFC. This is consistent with Hypothesis 4. Moreover, for firms of any size, the change in the likelihood of issuing a large bond after the GFC can be calculated from the estimated coefficients reported in Table 9, Panel A. These implied changes (which we label "marginal effects") are reported in Table 9, Panel B for firms of various sizes. Consistent with Hypothesis 5, we find that the marginal effects are zero for very small asset size, then rise as asset size increases, peaking at around the $90^{\text {th }}$ percentile, and decline toward zero thereafter. We interpret this as evidence that medium-sized emerging market firms see the greatest change in the probability of issuing large bonds. The changes reported in Panel B for medium-sized firms are large and statistically significant in emerging markets, but small and insignificant in developed economies. Figure 9 plots the probability of issuing large bonds, pre- and post-2008 for emerging and developed market firms, as a continuous function of asset size.

These results are consistent the view that a shift in bond investor demand for index-eligible debt acted as a treatment effect on emerging market bond issuers. Large 
firms were exogenously positioned, by virtue of their size, to better take advantage of the new issuance opportunities, which required firms to issue bonds of large size. Some medium-sized firms in emerging markets, seeking to borrow at unusually low rates available in the post-2008 environment, stretched and engaged in unprecedented issuance of large (index-eligible) bonds, which resulted in a relatively significant increase in the probability of large bond issuance by those firms.

\subsection{Uses of Funds from Large Bond Issuances by Firms of Different Sizes}

Lastly, we investigate the uses of funds by emerging market firms issuing largedenomination bonds. We focus on differences in the uses of funds by relatively small and large firms issuing them. Firms taking advantage of the yield discount in $\$ 500$ million bonds might be issuing bonds that are larger than the investment project opportunities they face. As a consequence, some large bond issuing firms might devote a larger share of the money raised in these issuances towards cash and short-term investments. To study this, we follow the methodology by Kim and Weisbach (2008) and Erel et al. (2012). We focus exclusively on the use of funds as measured by changes in cash and short-term investments.

We begin by calculating the accumulation of cash two years after each firm's bond issuance by estimating the following regression:

$$
\begin{aligned}
& \text { Cash }_{i c t}=\alpha_{c}+\alpha_{t}+\beta \log \left[1+\left(\frac{\text { Issuance }}{\text { Assets }}\right)_{i c t}\right] \\
& +\gamma \log \left[1+\left(\frac{\text { Other Sources }}{\text { Assets }}\right)_{i c t}\right]+Z_{i c t}+\varepsilon_{i c t},
\end{aligned}
$$


where Cash $=\log \left[\frac{V_{n}-V_{0}}{\text { Assets }}+1\right] . V$ stands for cash holdings and short-term investments. $n=2$ denotes the two-year time period considered for the analysis. ${ }^{27}$ Assets are the total assets of the firm in the year previous to the issuance. Other Sources = $\log \left[\frac{\sum_{i-1}^{n} \text { Total }_{\text {sources }}-\text { Issuance }}{\text { Assets }}+1\right]$, where total sources of funds represent the total funds generated by the firm internally and externally during a given year. $Z_{\text {ict }}$ are firm observable characteristics that we use as controls.

Figure 10, Panel A reports the results of estimating Equation (7) for the change in cash and short-term investments as dependent variable, controlling for the log of initial assets in the year before issuance, growth of sales, and the standard deviation of growth of sales. ${ }^{28}$ We report the dollar effects, breaking down our sample into different categories. ${ }^{29}$ We find that emerging market firms issuing $\$ 500$ million and above bonds tended to hold more cash after a bond issuance in post-2008 period relative to the pre-2008 period. Quantitatively, for every million-dollar raised before 2008, they held 0.12 million dollars in cash and short-term instruments two years after the issuance. The estimate for the post2008 period jumps to 0.71 million dollars. We note that Equation (10) is estimated with relatively few observations, which implies that the true increase may have been less, given that the coefficients are not estimated very precisely. We do not observe this increase in the use of cash and short-term instruments for emerging market firms issuing bonds

\footnotetext{
${ }^{27}$ Results for one year after a large bond issuance are similar to those reported for the two-year horizon, but the coefficients for the one-year horizon are larger for both relatively small and large firms. Using the second year mitigates the heterogeneity across firms related to the reporting dates of financial statements (given that offering dates occur at different times within the offering year). In addition, firms might take some time to spend the cash raised in their issuances, so cash holdings in the first year might not be too informative. Therefore, we confine our analysis to the two-year horizon.

${ }^{28} \mathrm{It}$ is conceivable that these results might be driven by selection bias. Emerging market firms that issued in the pre-2008 period differ on average from those issuing in the post-2008 period. There are several observable characteristics of firms that might be correlated with holdings of cash, such as the size of firms, their growth, and their uncertainty. We control for this possibility by adding these observables to the estimations.

${ }^{29}$ One potential concern is that firms might issue bonds of different sizes during a given year. However, firms issue these types of bonds infrequently. The average emerging market firm only issues bonds of this type once every 6.6 years (Appendix Table 10).
} 
smaller than $\$ 500$ million. Firms that issue these smaller bonds held 0.41 (0.25) million dollars per million dollars issued in before (after) 2008. We do not observe a similar increase for developed market firms (whose estimates decline from 0.49 to 0.34 ).

If the relatively small emerging market firms issuing large bonds were the ones stretching to take advantage of the yield discount in $\$ 500$ million bonds in the post-2008 period, then we should observe that these are the firms driving our results in the uses of funds, and specifically the accumulation of cash. In Figure 10, Panel B, we present the Kim and Weisbach (2008) analysis for the post-2008 period for emerging market firms, dividing companies that issued large bonds into high- and low-asset firms (above and below the country median of assets, respectively). During this period, relatively small firms issuing large bonds tended to hold much more cash than large firms issuing large bonds, consistent with our prediction.

\section{Conclusions}

The GFC led to a persistent period of low interest rates throughout the developed world. This low interest rate environment produced a search for yield by institutional investors that favored some classes of global securities, such as emerging market corporate debt, that had not been as popular among developed countries' institutional investors prior to the crisis. In this paper, we show that institutional investors searching for yield in emerging market corporate debt after 2008 favored corporate debt securities that were large enough to qualify for inclusion in market indexes.

Inclusion in market indexes provides a liquidity benefit to investors in these bonds because holding a portfolio of bonds included in the index improves the liquidity of investors' positions. Mutual funds that track a market index also benefit from holding bonds in the index; doing so reduces the risk that their performance will deviate from the market benchmark. The benefits of index inclusion are especially attractive for cross-over 
fund investors, which manage a considerable pool of assets, lack experience with emerging market corporate debt, and favor liquidity. Indeed, we find that cross-over funds hold especially significant proportions of large, index-eligible emerging market corporate debt.

The sudden rise in the demand for emerging market corporate debt by fund investors produced a sizeable increase in the yield discount associated with index eligibility, and a large increase in the proportion of issuance of large, index-eligible corporate debt. The financial rewards of issuing index-eligible debt after 2008 were significant. Firms able to issue a $\$ 500$ million bond, rather than, say, a $\$ 400$ million bond, saved close to a full percentage point in yield to maturity. These changes in issuance size were not apparent for investment grade developed country corporate bond issuances, which by virtue of their lower preexisting risk and greater ability to attract institutional investors in the pre-2008 era were less affected by the search for yield after 2008 .

Large size emerging economy firms were exogenously better positioned to take advantage of the new opportunities to issue large bonds at lower yields. Medium-sized emerging economy firms, however, saw the greatest change in the probability of issuing large bonds. These medium-sized issuers who stretched and issued large bonds were willing to retain significant amounts of cash from the proceeds of their bond issuances to access funds at a lower cost.

Our findings raise important questions for future research. First, because the increased discount on emerging market corporate debt was larger for risky debt, it might have constituted a subsidy for greater risk taking. Did firms respond to this subsidy by increasing the riskiness of their operations? Second, with respect to the extra cash holdings of relatively small firms issuing large bonds after 2008 , how did the combination of dollardenominated debt and domestic cash holdings affect their exposure to exchange rate risk, and their other risk-management practices? Also, if equity capital is scarce, did the combination of increased leverage and additional cash from bond issuance by medium- 
sized firms that stretched to raise their issuance amount crowd in or crowd out productive investments? Third, in our empirical analysis our data did not permit us to distinguish between the two alternative drivers of the yield discount for index eligibility (greater liquidity or reduced tracking error). If liquidity is relatively important, then one would expect that fund demand for index-eligible debt should be greater for debt with lower bidask spreads. If tracking error is relatively important, then even relatively illiquid debt in the index would enjoy substantial yield discounts in the primary market. Furthermore, tracking error should be relatively unimportant for funds that do not track the CEMBI index. 


\section{References}

Acharya, V., S. Cecchetti, J. de Gregorio, S. Kalemli-Ozcan, P. Lane, and U. Panizza (2015). "Corporate Debt in Emerging Economies: A Threat to Financial Stability?" Brookings Institution, Committee on International Economic Policy and Reform.

Adrian, T., P. Colla, and H.S. Shin, (2013). "Which Financial Frictions? Parsing the Evidence from the Financial Crisis of 2007 to 2009." In NBER Macroeconomics Annual 2012, Vol. 27, edited by D. Acemoglu, J. Parker, and M. Woodford, University of Chicago Press, 159-214.

Barberis, N., A. Shleifer, and J. Wurgler (2005). "Comovement." Journal of Financial Economics 75(2), 283-317.

Bates, T., K.M. Kahle, and R.M. Stulz (2009). "Why Do U.S. Firms Hold So Much More Cash than They Used To?" Journal of Finance, 64(5), 1985-2021.

Becker, B. and V. Ivashina (2014). "Cyclicality of Credit Supply: Firm-Level Evidence." Journal of Monetary Economics 62(C), 76-93.

Becker, B. and V. Ivashina (2015). "Reaching for Yield in the Bond Market." Journal of Finance 70(5), 1863-1902.

Begenau, J. and B. Palazzo (2017). "Firm Selection and Corporate Cash Holdings." National Bureau of Economic Research, Working Paper 23249.

Beim, D.O., and C.W. Calomiris (2001). "Emerging Financial Markets." McGrawHill/Irwin, 2001.

Bruno, V. and H.S. Shin (2017). "Global Dollar Credit and Carry Trades: A Firm-level Analysis." Review of Financial Studies 30(3), 703-749.

Calomiris, C.W. and H. Mamaysky (2019). "How News and Its Context Drive Risk and Returns Around the World." Journal of Financial Economics, forthcoming.

Carabin, M., A. de la Garza, and O. Moreno (2015). "Global Liquidity and Corporate Financing in Mexico." Bank of Mexico, Mimeo.

Chang, Y.C., H.G. Hong, and I. Liskovich (2015). "Regression Discontinuity and the Price Effects of Stock Market Indexing." Review of Financial Studies 28(1), 212-246.

Chen, H., G. Noronha, and V. Singal (2004). "The Price Response to S\&P 500 Index Additions and Deletions: Evidence of Asymmetry and a New Explanation." Journal of Finance 59(4), 1901-1930.

Chui, M., I. Fender, and V. Sushko (2014). "Risks Related to EME Corporate Balance Sheets: The Role of Leverage and Currency Mismatch." BIS Quarterly Review, September 2014, 35-47.

Chui, M., E. Kuruc, and P. Turner (2016). "A New Dimension to Currency Mismatches in the Emerging Markets-Non-Financial Companies." Bank of International Settlements, Working Paper 550.

Claessens, S. and Y. Yafeh (2013). "Comovement of Newly Added Stocks with National Market Indices: Evidence from Around the World.” Review of Finance 17(1), 203-227.

Converse, N., E. Levy-Yeyati, and T. Williams (2018). "How ETFs Amplify the Global Financial Cycle in Emerging Markets." Institute of International Economic Policy, Working Paper 2018-1.

Cortina, J., T. Didier, and S. Schmukler (2018). "Corporate Borrowing and Debt Maturity: The Effects of Market Access and Crises." CEPR Discussion Paper DP13008 and Mo.Fi.R. Working Paper 149.

Cremers, M. and A. Petajisto (2009). "How Active Is Your Fund Manager? A New Measure that Predicts Performance." Review of Financial Studies, 22(9), 3329-3365.

Cremers, M., M. Ferreira, P. Matos, and L. Starks (2016). "Indexing and Active Fund Management: International Evidence." Journal of Financial Economics, 120(3), 539-560.

Dathan, M. and S.A. Davydenko (2018). "Debt Issuance in the Era of Passive Investment." University of Toronto, Mimeo. 
Du, W. and J. Schreger (2016). "Local Currency Sovereign Risk.” Journal of Finance 71(3), 1027-1070.

Duffie, D., P. Dworczak, and H. Zhu (2017). "Benchmarks in Search Markets." Journal of Finance, 72(5), 1983-2044.

Erel, I., B. Julio, W. Kim, and M. Weisbach (2012). "Macroeconomic Conditions and Capital Raising." Review of Financial Studies, 25(2), 341-376.

Falato, A., D. Kadyrzhanova, J. Sim, and R. Steri (2013). "Rising Intangible Capital, Shrinking Debt Capacity, and the US Corporate Savings Glut." Board of Governors of the Federal Reserve System, Finance and Economics Discussion Series 2013-67.

Feyen, E., K. Gosh, K. Kibuuka, and S. Farazi (2015). "Global Liquidity and External Bond Issuance in Emerging Economies and Developing Economies." World Bank, Research Working Paper 7363.

Goldstein, I., H. Jiang, and D.T. Ng (2017). "Investor Flows and Fragility in Corporate Bond Funds." Journal of Financial Economics 126(3), 592-613.

Greenwood, R. (2005). "Short- and Long-Term Demand Curves for Stocks: Theory and Evidence on the Dynamics of Arbitrage." Journal of Financial Economics 75(3), 607649.

Harris, L.E. and E. Gurel (1986). "Price and Volume Effects Associated with Changes in the S\&P 500 List: New Evidence for the Existence of Price Pressures." Journal of Finance 41(4), 815-829.

Hau, H., M. Massa, and J. Peress (2010). "Do Demand Curves for Currencies Slope Down? Evidence from the MSCI Global Index Change." Review of Financial Studies 23(4), 1681-1717.

Jiang, Z., A. Krishnamurthy, and H. Lustig (2018). "Foreign Safe Asset Demand and The Dollar Exchange Rate." National Bureau of Economic Research, Working Paper 24439.

Jiang, Z., A. Krishnamurthy, and H. Lustig (2019). "Dollar Safety and The Global Financial Cycle." Graduate School of Stanford Business, Mimeo.

Kaminsky, G., and S. Schmukler (2008). "Short-Run Pain, Long-Run Gain: Financial Liberalization and Stock Market Cycles." Review of Finance, 12(2), 253-292.

Karolyi, G.A. (2015). Cracking the Emerging Markets Enigma. Oxford University Press, 2015.

Kashyap, A.K., N. Kovrijnykh, J. Li, and A. Pavalova (2018). "The Benchmark Inclusion Subsidy." National Bureau of Economic Research, Working Paper 25337.

Kim, W. and M. Weisbach (2008). "Motivations for Public Equity Offers." Journal of Financial Economics 87(2), 281-307.

Lo Duca, M, Nicoletti, G., and A. Vidal Martinez (2016). "Global Corporate Bond Issuance: What Role for US Quantitative Easing?" Journal of International Money and Finance, 60, 114-150.

Pandolfi, L. and T. Williams (2019). "Capital Flows and Sovereign Debt Markets: Evidence from Index Rebalancings." Journal of Financial Economics, forthcoming.

Raddatz, C., S. Schmukler, and T. Williams (2017). "International Asset Allocations and Capital Flows: The Benchmark Effect." Journal of International Economics, 108, 413430.

Ramos, M. and S. Garcia (2015). "Is Trouble Brewing for EMEs?" Bank of Mexico, Working Paper 2015-08.

Shek, J., I. Shim, and H.S. Shin (2017). "Investor Redemptions and Fund Manager Discretionary Sales of EME Bonds: How Are They Related?” Review of Finance 22(1), 207-241.

Shin, H.S. (2013). "The Second Phase of Global Liquidity and its Impact on Emerging Economies." Keynote Address at Federal Reserve Bank of San Francisco, Asia Economic Policy Conference. 
Shleifer, A. (1986). "Do Demand Curves for Stocks Slope Down?” Journal of Finance 41(3), $579-590$.

Wurgler, J. (2011). “On the Economic Consequences of Index-Linked Investing." In Challenges to Business in the Twenty-First Century: The Way Forward, edited by G. Rosenfeld, J. Lorsch, and R. Khurana, American Academy of Arts and Sciences, 2034.

Xiao, J. (2018). "Corporate Debt Structure, Precautionary Savings, and Investment Dynamics." Meeting Papers 887, Society for Economic Dynamics. 


\section{Appendix 1. The Emerging Market Debt Index Universe}

There are relatively few indexes that track emerging market corporate debt denominated in foreign currencies. The most prominent index provider companies that cater to investors interested in emerging market debt are Barclays/Bloomberg, Citigroup, and J.P. Morgan. Among them, J.P. Morgan is arguably the leader in the emerging market segment in terms of the funds that track their performance against its indexes. For instance, as of July 2017, EPFR Global tracks the performance of 450 specialized emerging market debt funds. Of those, 394 funds (88\%) declared to be tracking their performance against a J.P. Morgan index. These funds had $\$ 317$ billion under management, and $\$ 280$ billion (88\%) of those assets are benchmarked against J.P. Morgan indexes.

Throughout the paper we focus on the important J.P. Morgan bond indexes. There are three broad families of J.P. Morgan emerging market indexes: the CEMBI (corporate debt denominated in U.S. dollars), the EMBI (sovereign and quasi-sovereign debt denominated in U.S. dollars), and the GBI (sovereign debt denominated in local currency). Appendix Figure 1 presents the assets under management of funds that track their performance against J.P. Morgan indexes divided by family type. Appendix Table 2 presents the different requirements that a bond must fulfill to enter the most popular J.P. Morgan indexes in this segment: the CEMBI Broad Diversified, the CEMBI Narrow Diversified, and the EMBI Global Diversified. 


\section{Appendix 2. Fund Classification with Morningstar Direct Mutual Fund Data}

We classify Morningstar funds into emerging market corporate specialists and cross-over categories. The cross-over category is also sub-divided into developed markets, emerging market sovereign, and emerging market mixed. To categorize funds, we use the Morningstar "global category," which Morningstar created by analyzing the composition of mutual fund portfolios. We consider a fund as emerging market if its global category in Morningstar is "Emerging Markets Fixed Income," "Africa Fixed Income," "India Fixed Income," "Latin America Fixed Income," or "Mexico Fixed Income." We classify the other funds in the database as developed markets, because they do not seem to be related to emerging markets.

Emerging market funds are subdivided into corporate, sovereign, and mixed funds, using the Morningstar variable "primary prospectus benchmark." This variable indicates which index or group of indexes a fund is benchmarked against. If a fund is solely benchmarked against a corporate (sovereign) bond index or indexes, it is classified as corporate (sovereign). If a fund is benchmarked against a bond index that follows both corporate and sovereign bonds (disregarding their share in the index) or a group of indexes that include corporate and sovereign indexes, it is classified as mixed.

To determine whether the funds are benchmarked against a corporate, sovereign, or mixed bond index or indexes, we used the following guidelines. J.P. Morgan CEMBI indexes and indexes with "corporate" or "non-sovereign" in their name are classified as corporate. J.P. Morgan EMBI and GBI-EM indexes are classified as sovereign. J.P. Morgan ELMI+ indexes are classified as mixed because they are money market indexes. Indexes with "government," "treasury," "sovereign," or a similar term in their name are classified as sovereign. For the funds in the database that do not fall into the guidelines described above or whose "primary prospectus benchmark" is not available, we searched manually the composition of their holdings through Morningstar, the Financial Times, or the official 
fund's website to determine whether the fund should be classified as corporate, sovereign, or mixed. If a fund only holds corporate (sovereign) bonds in its portfolio, it is classified as corporate (sovereign). If a fund holds both corporate and sovereign bonds, it is classified as mixed. 


\section{Figure 1}

\section{Model-Based Cumulative Distribution of Issuance Size}

This figure plots the model-based cumulative distribution of issuance size. $I$ denotes issuance size, $G(I)$ denotes the cumulative distribution of issuance size, and X denotes firm size (which represents the size of the firm's investment opportunity). Firms of size below $\widehat{X}$ issue $X$, firms in the size interval $[\widehat{X}: 500]$ issue 500 , and firms of size greater or equal than 500 issue $\mathrm{X}$. Because of the opportunity cost of cash, there are no bond issuances of size $[\widehat{\mathrm{X}}: 500)$. Panel A plots the cumulative distribution of issuance size for a given $\widehat{\mathrm{X}}$. Panel B shows how the cumulative distribution of issuance size changes when the size yield discount (D) increases (which decreases $\widehat{X}$ ).

Panel A. Cumulative Distribution of Issuance Size

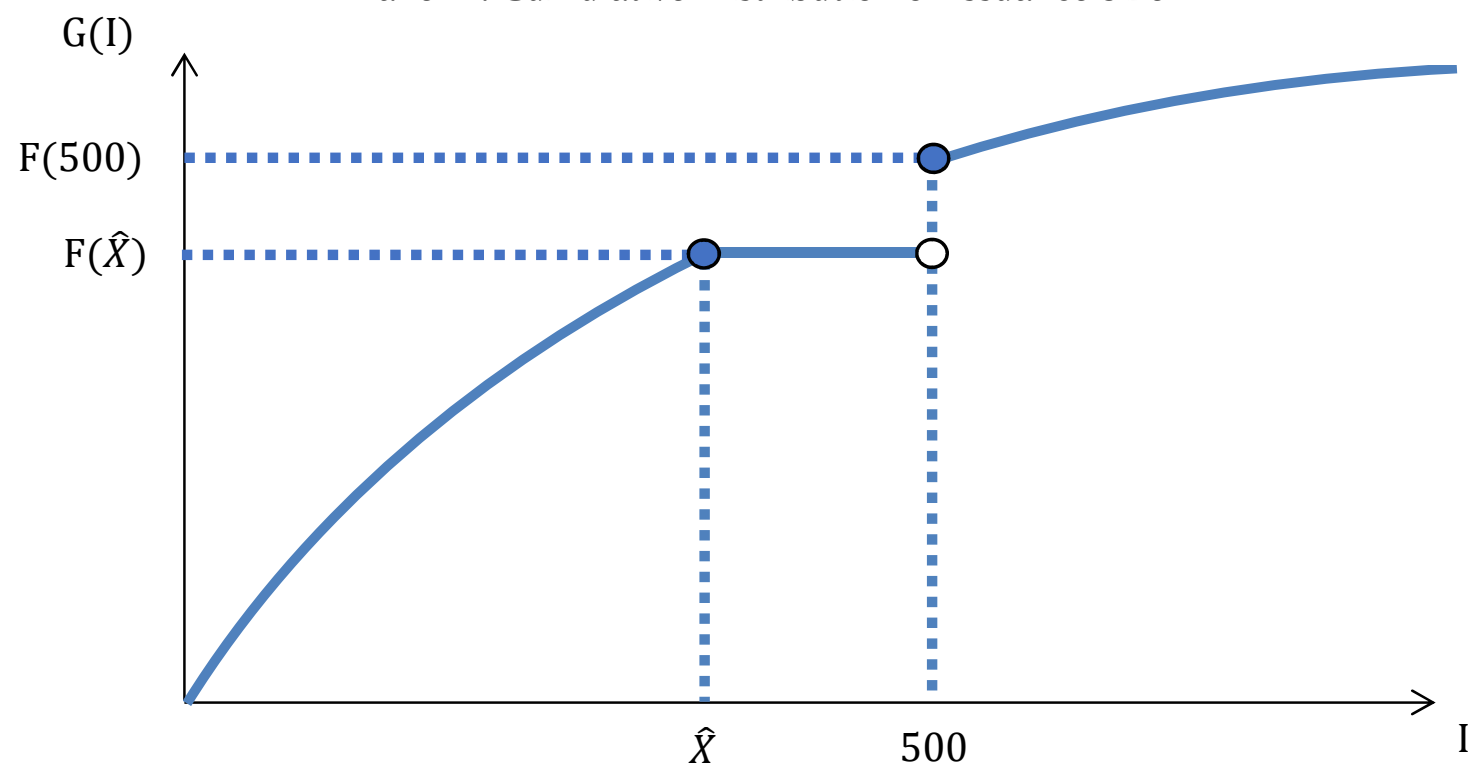

Panel B. Effect of an Increase in the Size Yield Discount (D)

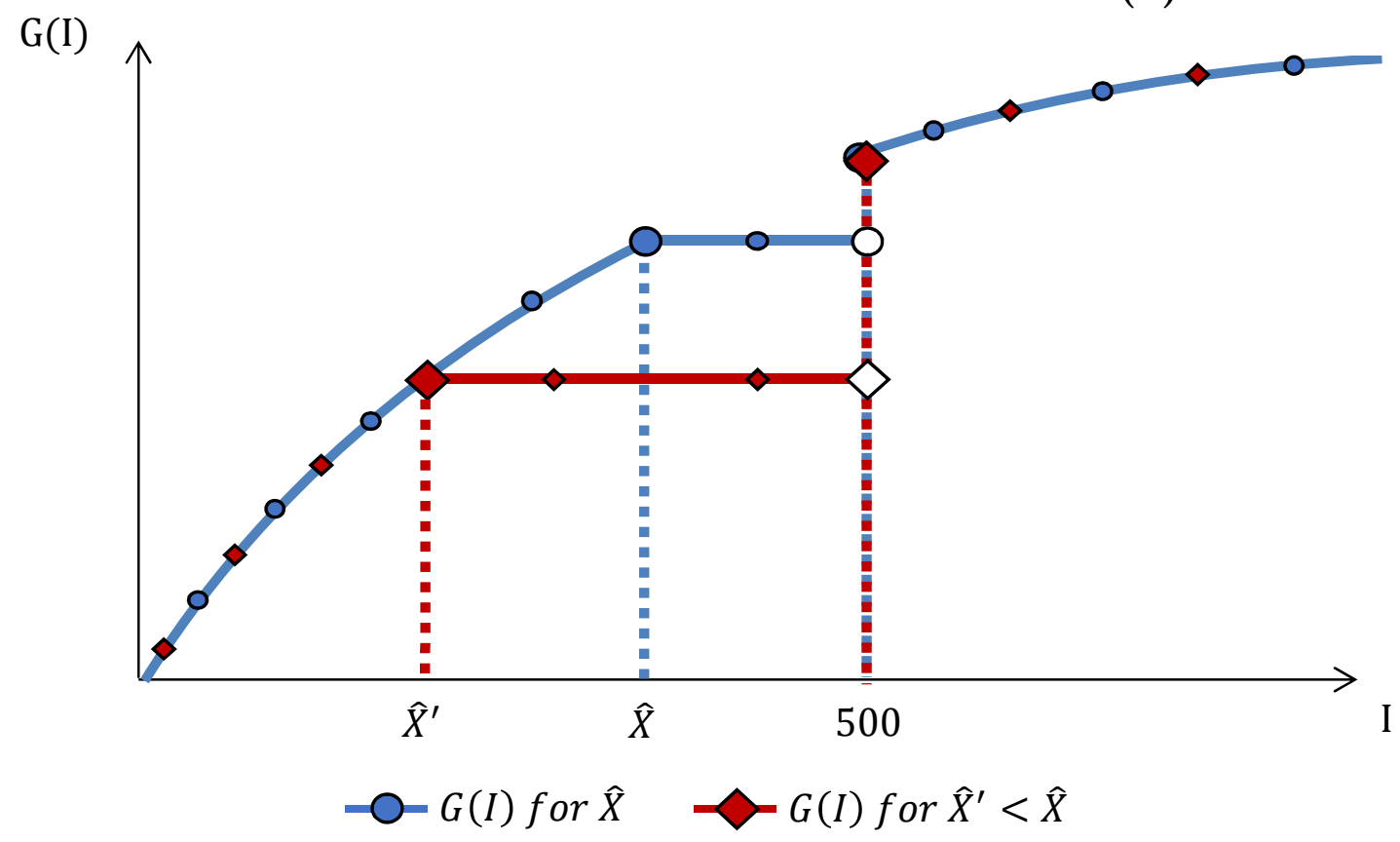


Figure 2

Yield to Maturity of U.S. Dollar Corporate Bonds Issued by Emerging Markets

This figure shows the yield to maturity of international U.S. dollar-denominated bonds issued by firms in emerging markets during 2000-2016. The lines show the average yield to maturity of bonds issued with face values below $\$ 300$ million (0:300), between $\$ 300$ and $\$ 500$ million [300:500), and equal to or above $\$ 500$ million [500:1,000), respectively.

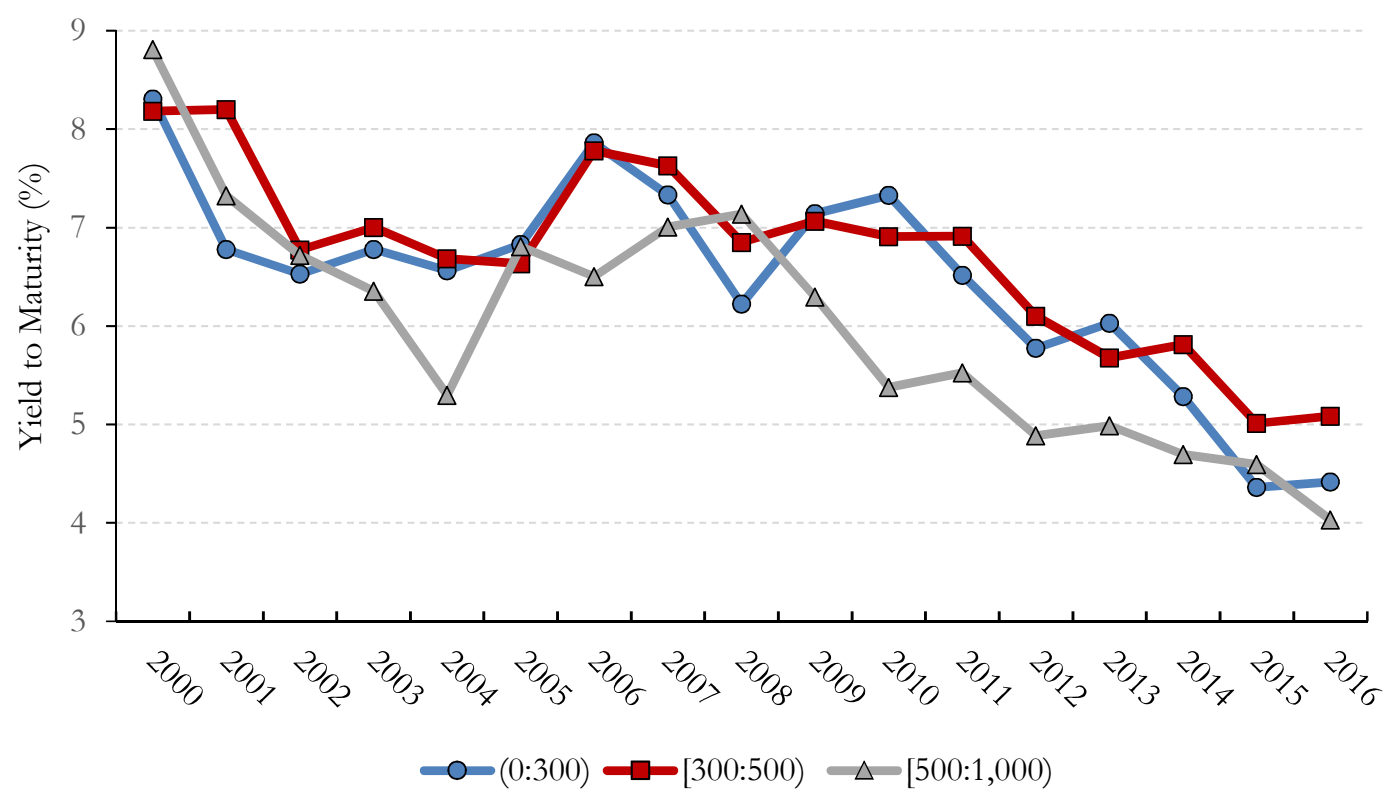




\section{Figure 3}

\section{Yield to Maturity of Issuances, Pre and Post 2008}

This figure shows the average yield to maturity of international U.S. dollar-denominated bonds of different issuance sizes in millions of U.S. dollars for firms in emerging markets (Panel A) and investment grade firms in developed markets (Panel B) during the pre-2008 (2000-2008) and post-2008 (2009-2016) periods.

\section{Panel A. Emerging Markets}

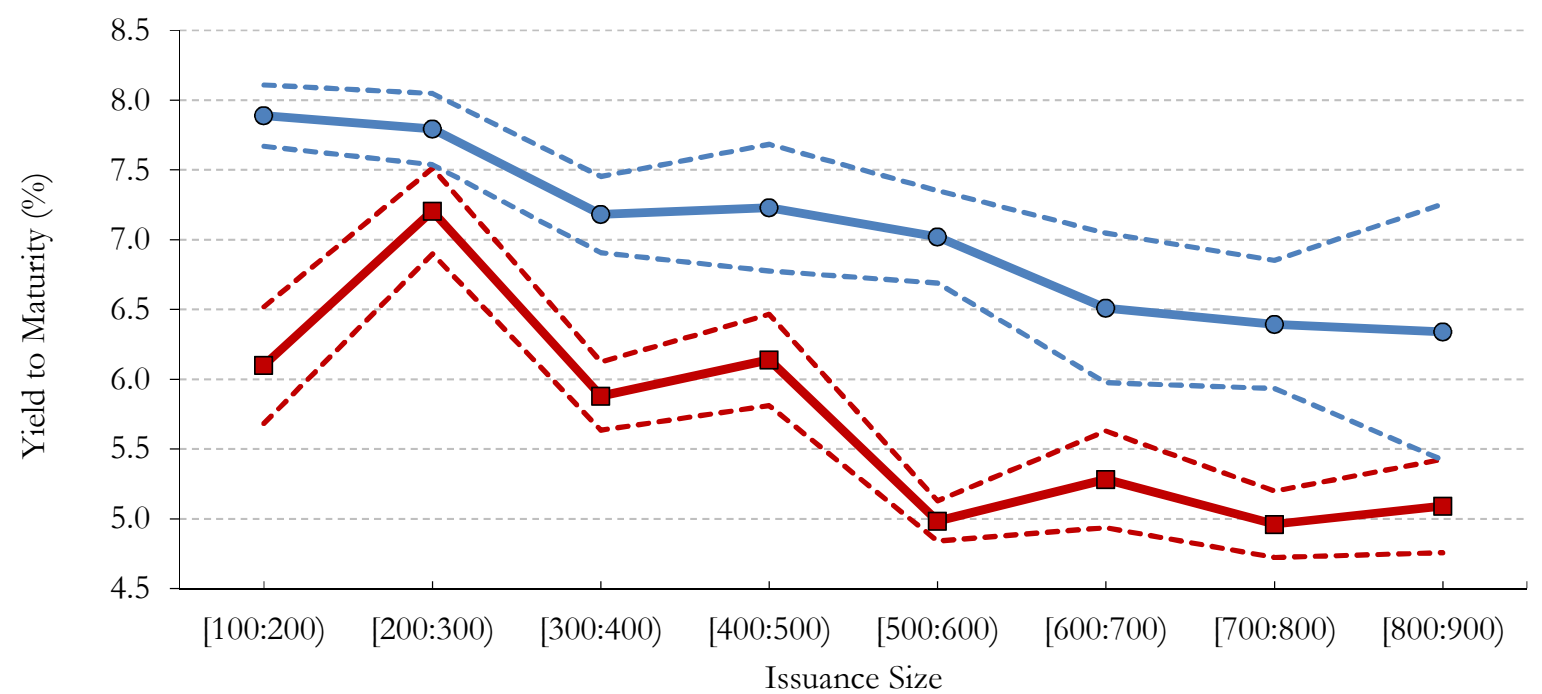

Panel B. Developed Markets

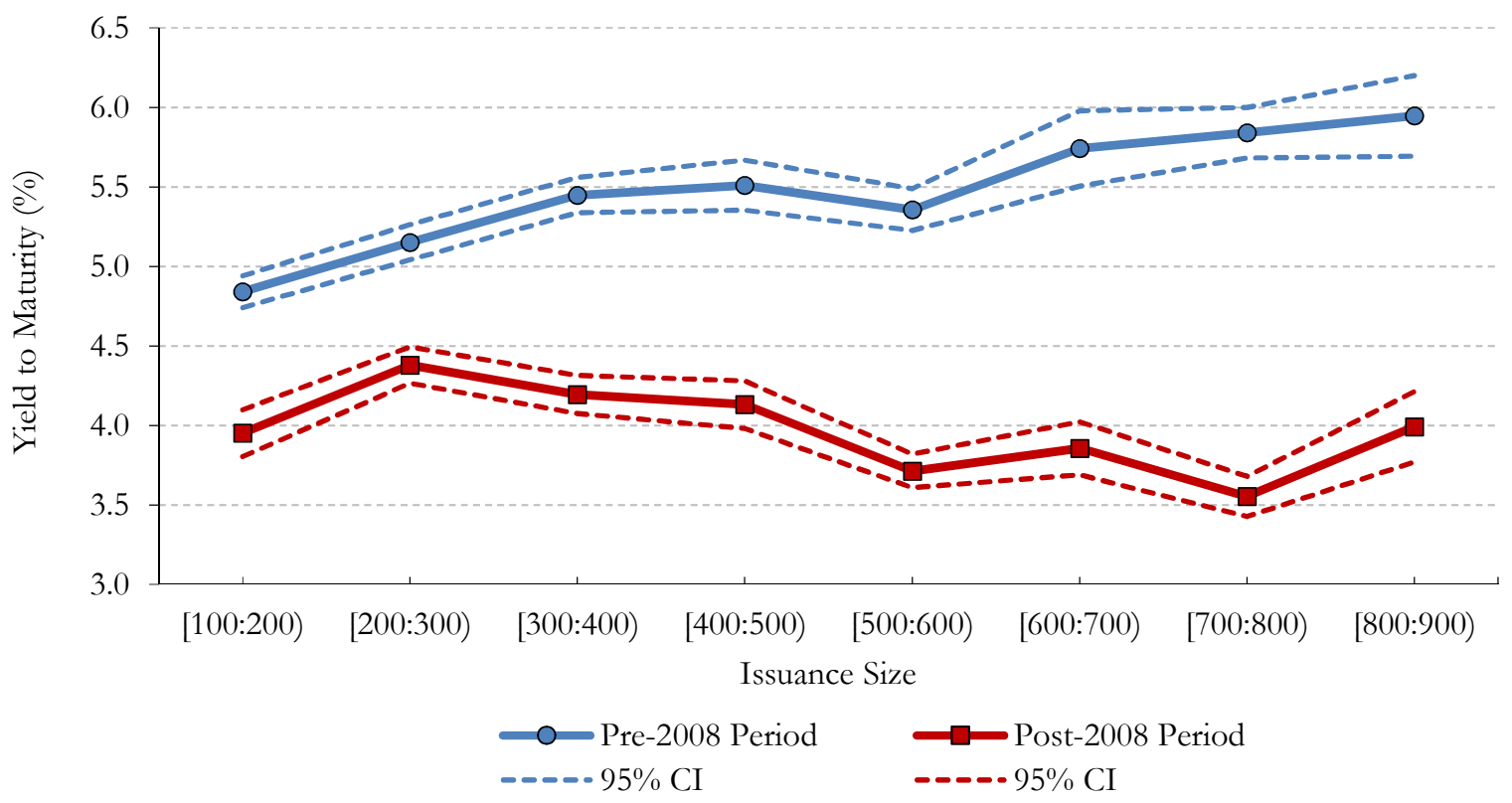




\section{Figure 4}

Value and Number of U.S. Dollar Corporate Bonds Issued by Emerging Markets

This figure shows the total value (Panel A) and the total number (Panel B) of international U.S. dollar-denominated bonds issued by firms in emerging markets during 2000-2016. The areas represent bonds issued with different face values in millions of U.S. dollars. The total value of bonds is measured in billions of 2011 U.S. dollars.

\section{Panel A. Total Value of Bonds}

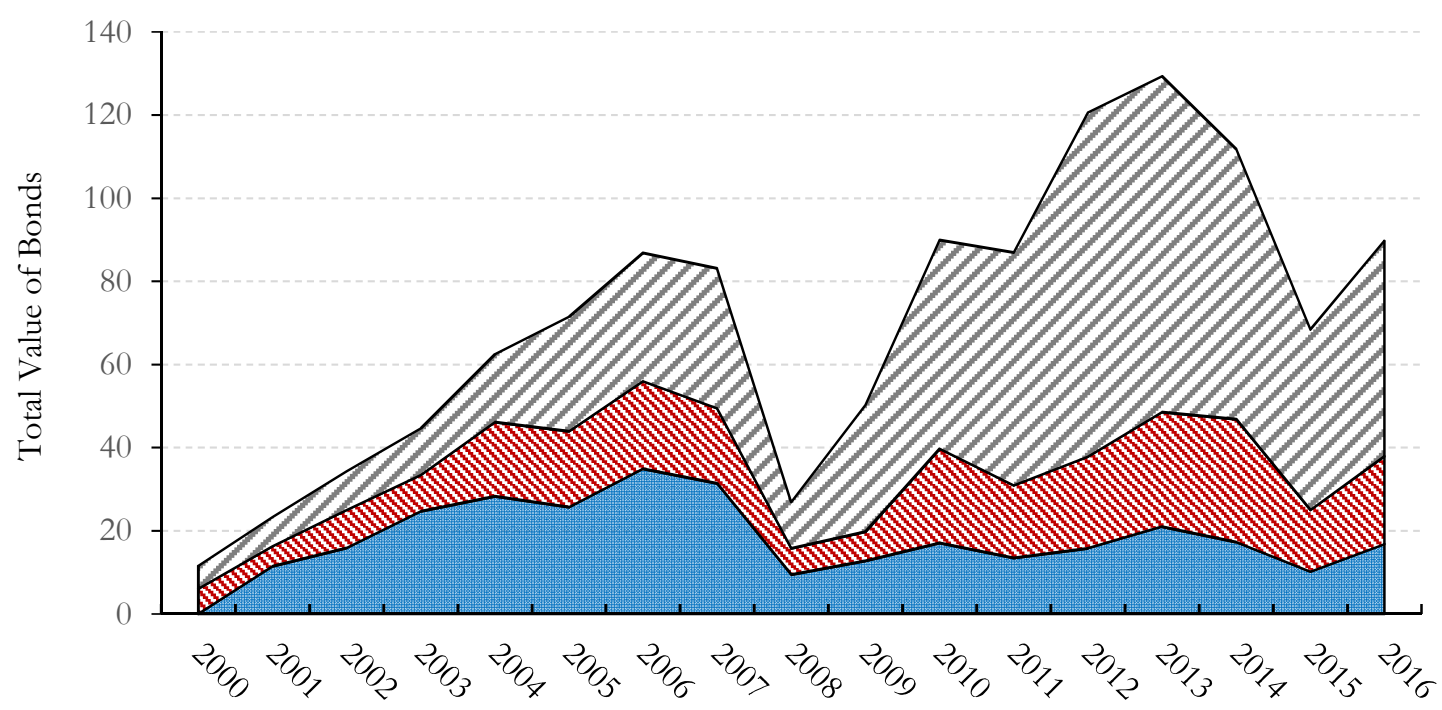

Panel B. Total Number of Bonds

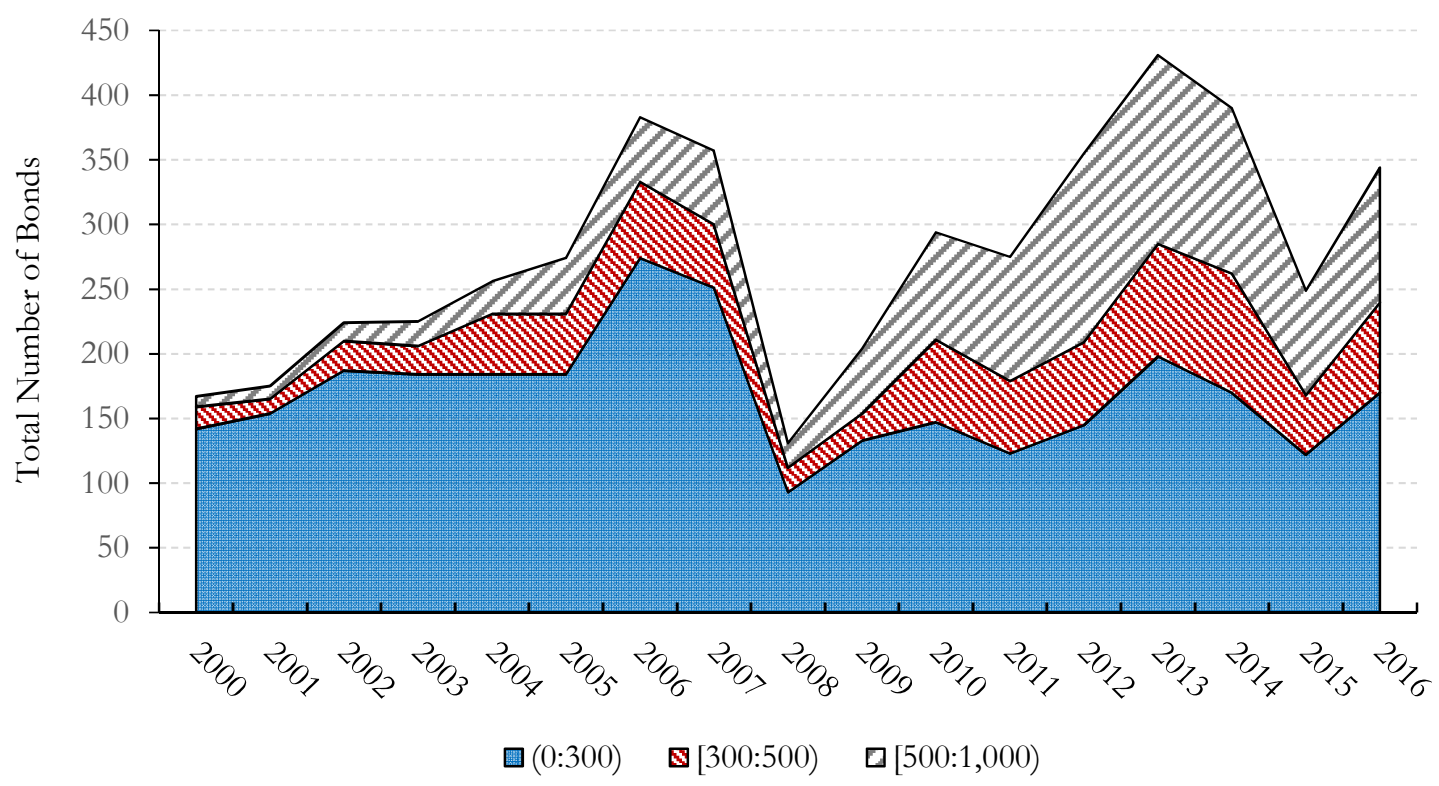




\section{Figure 5}

\section{Cumulative Distribution of Issuance Size, Pre and Post 2008}

This figure shows the cumulative distribution of international U.S. dollar-denominated bond issuances by size in millions of U.S. dollars for emerging market firms (Panel A) and investment grade developed market firms (Panel B) during the pre-2008 (2000-2008) and post-2008 (2009-2016) periods.

\section{Panel A. Emerging Markets}

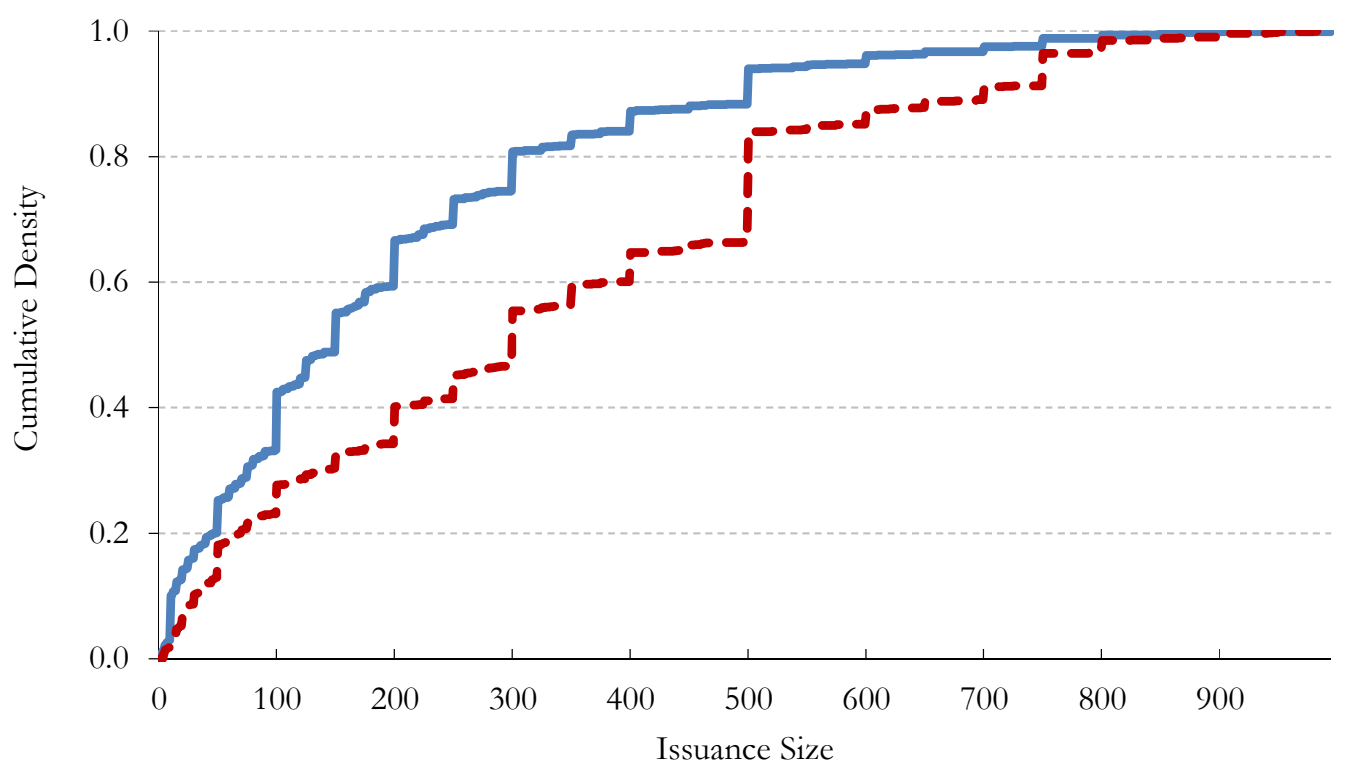

Panel B. Developed Markets

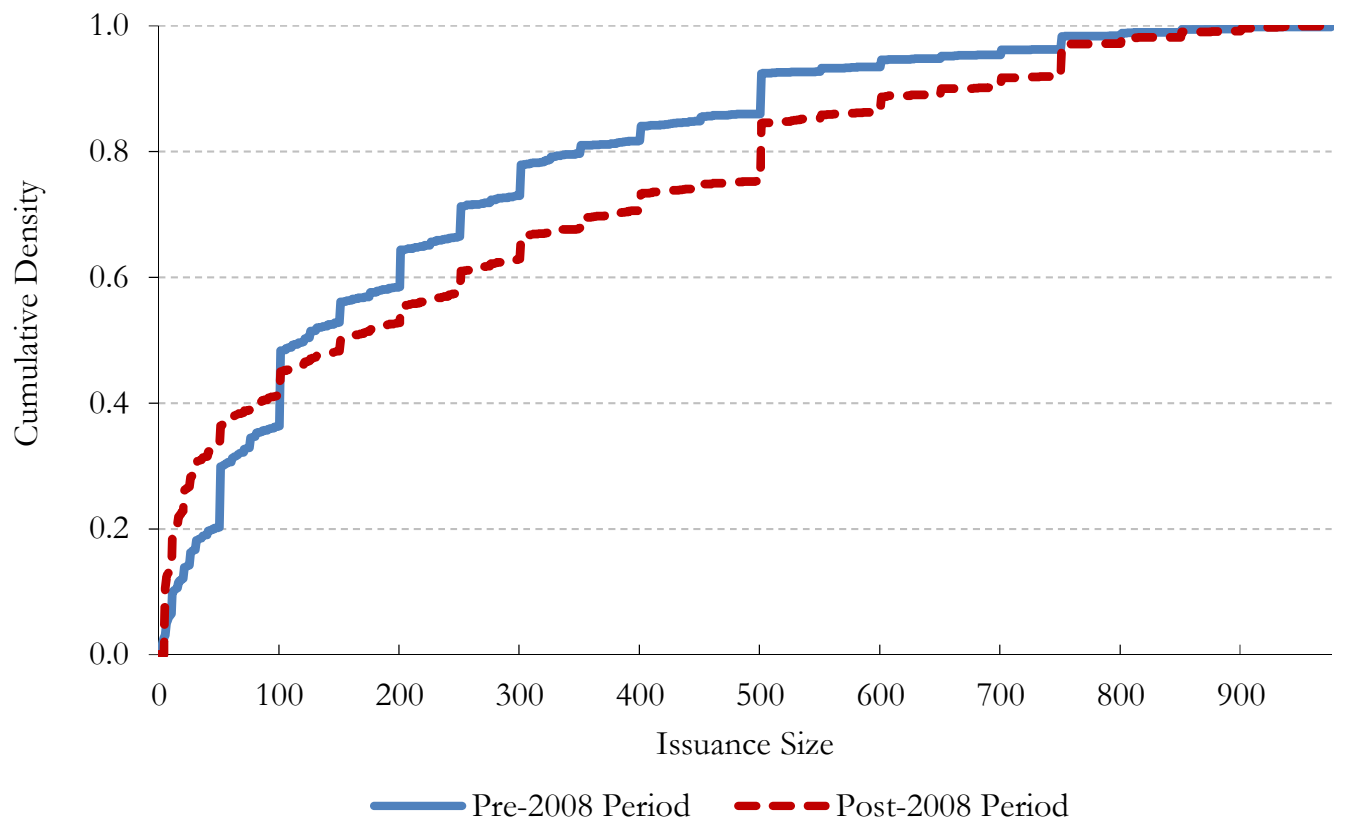


Figure 6

Yield to Maturity and Corporate Bond Issuances of \$500 Million

This figure shows the evolution of the yield to maturity and the percentage of international $\$ 500$ million corporate bond issuances during 2000-2016. Panel A displays the average yield to maturity in each year for $\$ 500$ million bond issuances. Panel B shows the average number of bond issuances of size equal to $\$ 500$ million, relative to the total number of bond issuances. The series display percent values for emerging market firms and investment grade developed market firms during 2000-2016.

\section{Panel A. Yield to Maturity}

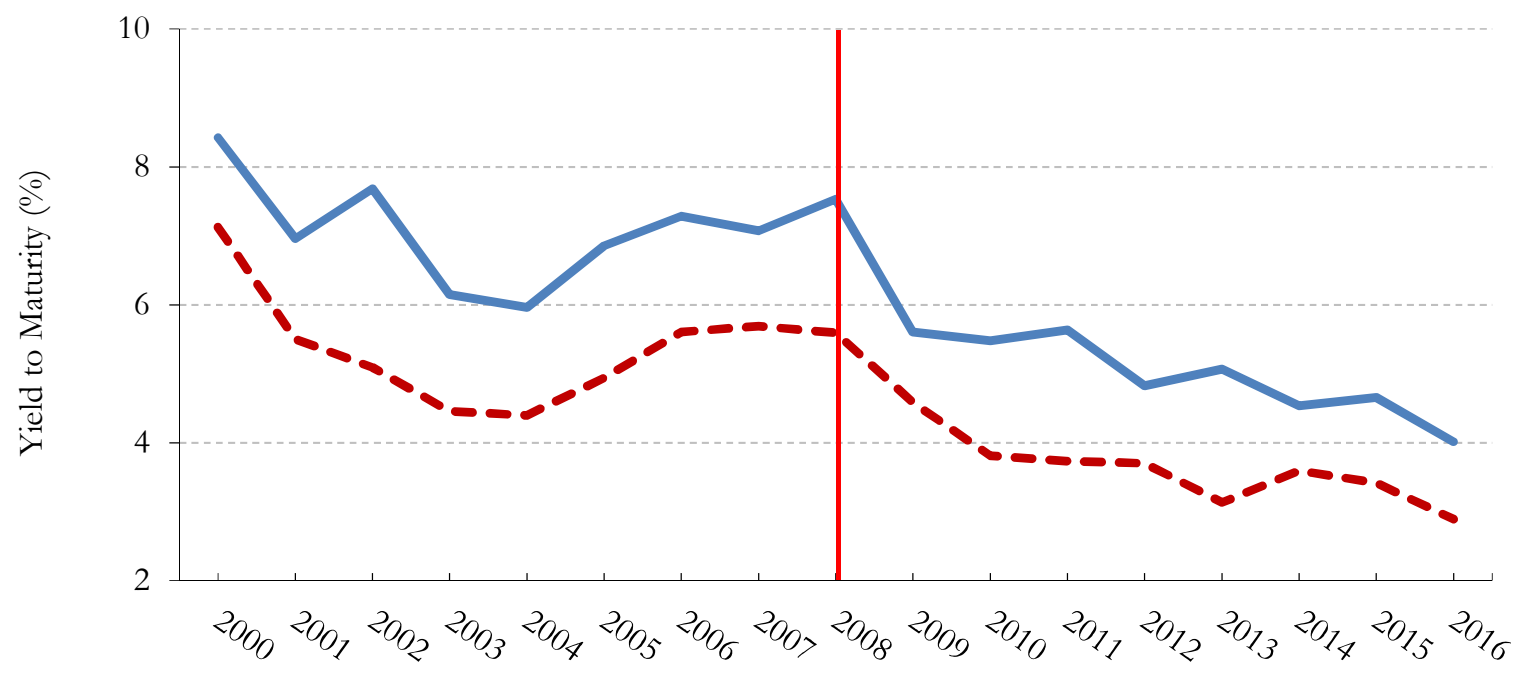

Panel B. Issuances

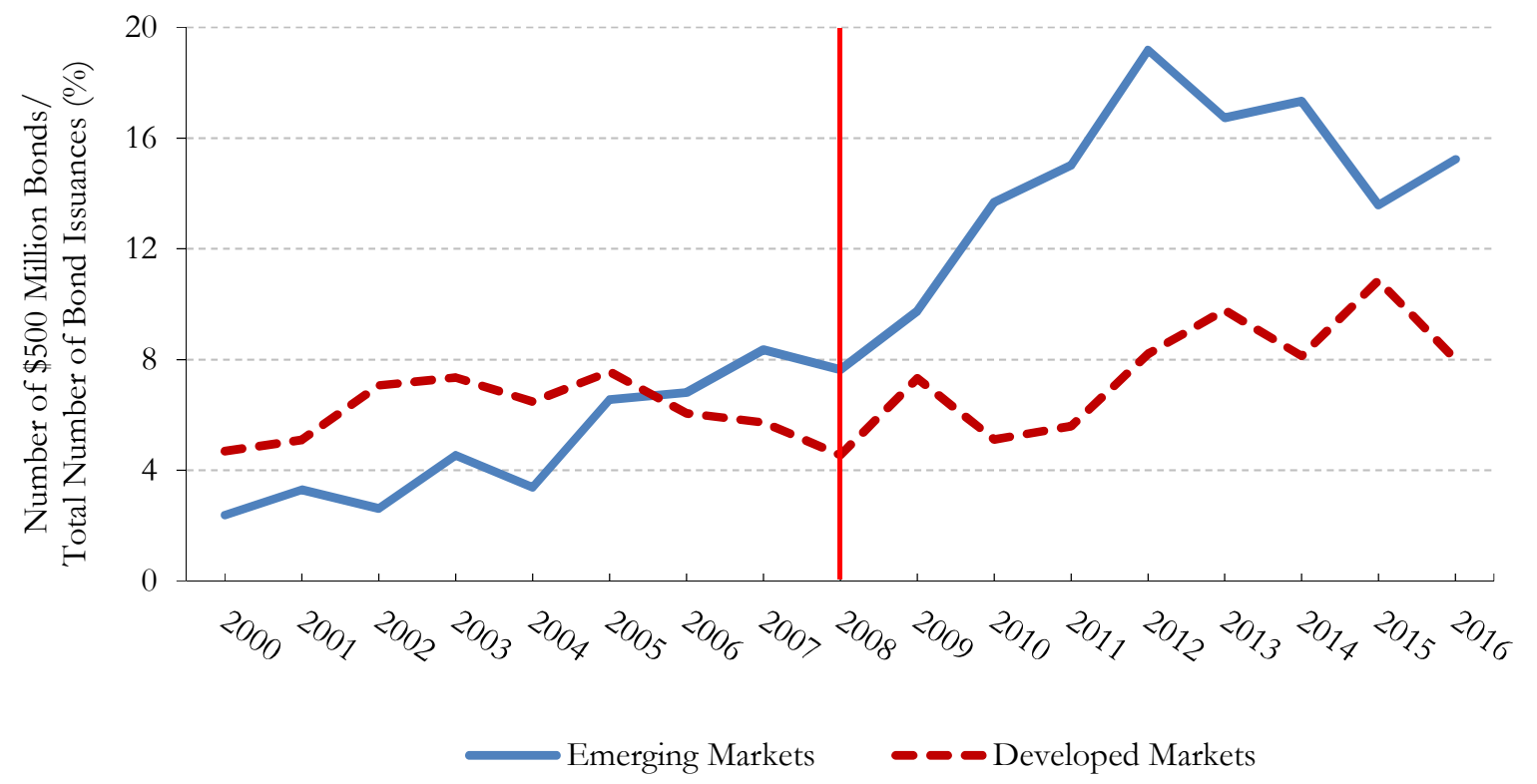




\section{Figure 7}

\section{Mutual Fund Investments in Emerging Markets}

Panel A shows the cumulative flows into emerging market sovereign and corporate debt funds in billions of U.S. dollars and the share of international $\$ 500$ million bond issuances during 2003-2016. The latter share is calculated as the number of international $\$ 500$ million bonds issued by emerging market firms relative to all international dollar-denominated bonds issued by these firms. The correlation coefficients between the two time series are reported at the top of the figure. Panel B shows the weight of developed market mutual funds in emerging market sovereign and corporate debt during 2005-2016.

\section{Panel A. Flows into Emerging Market Debt and Share of \$500 Million Bonds}

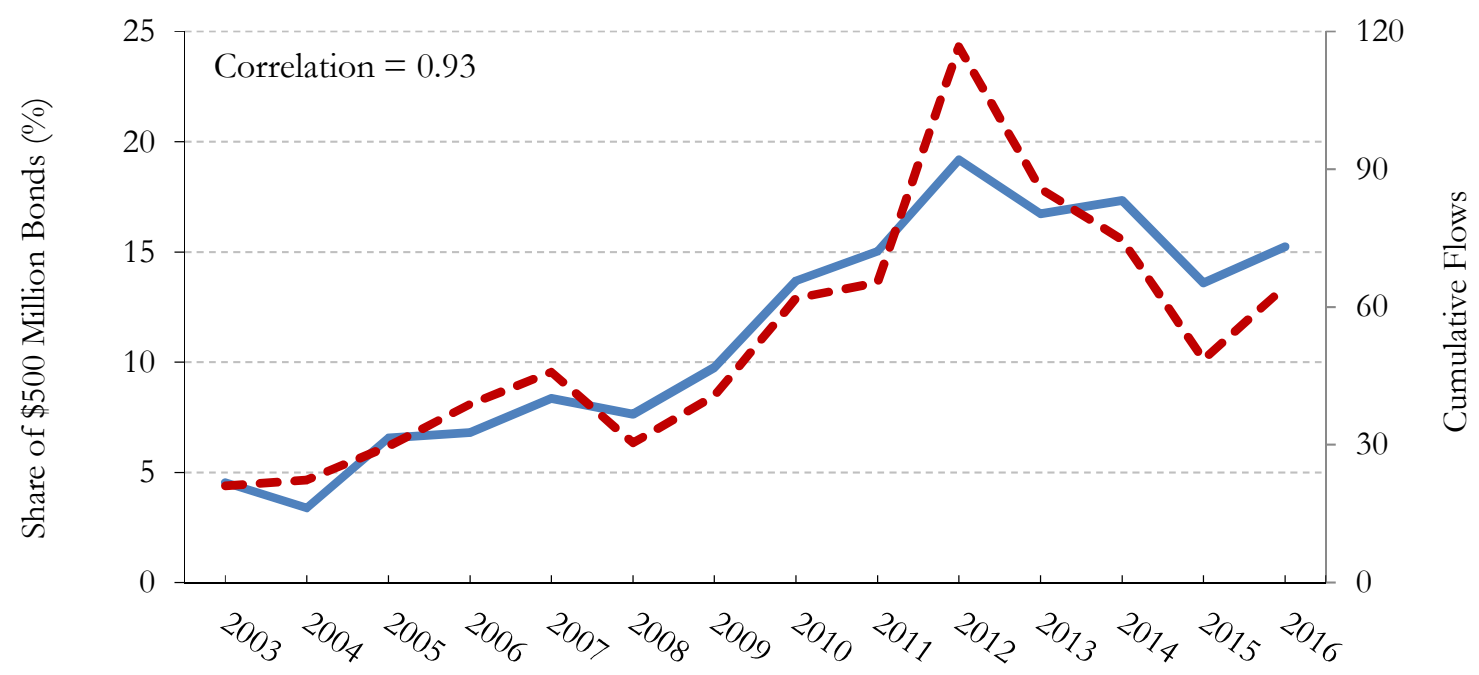

Number of $\$ 500$ Million Bonds/Total Number of Bonds (Left Axis)

- Cumulative Flows to Emerging Market Debt Funds (Right Axis)

\section{Panel B. Weight in Emerging Markets of Developed Market Mutual Funds}

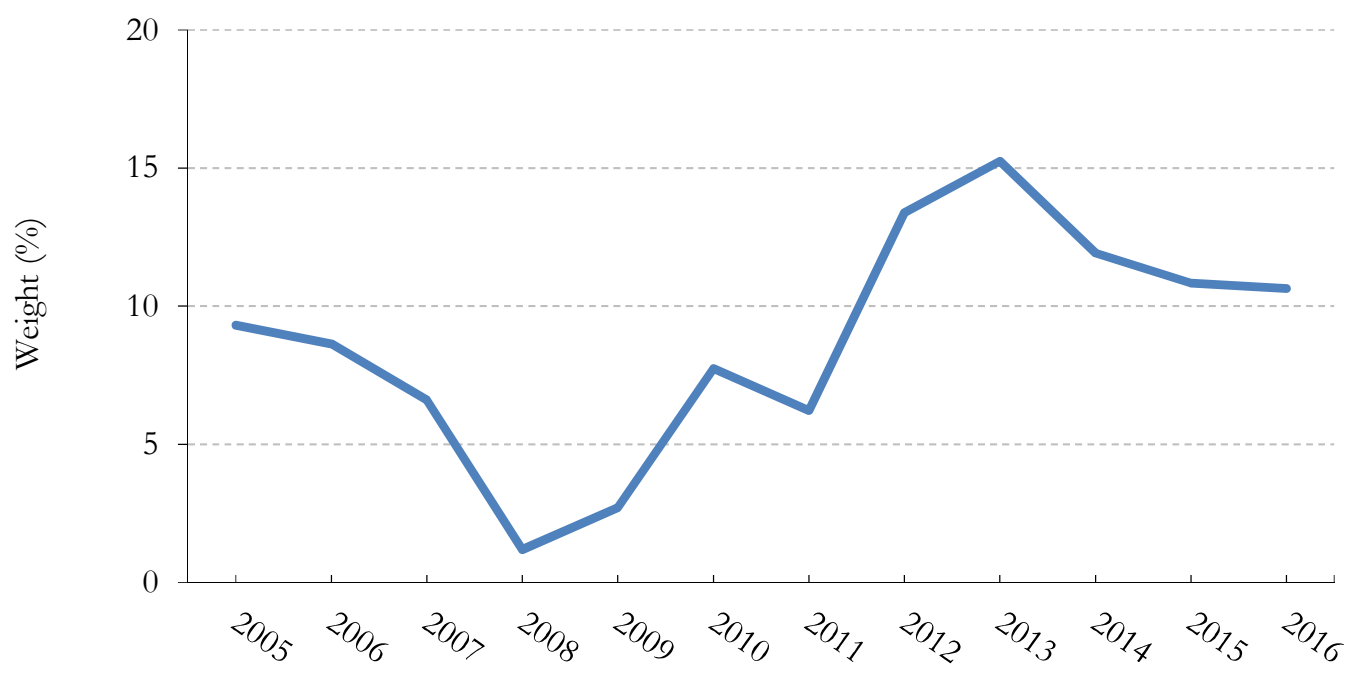

Median Exposure to Emerging Markets of Developed Market Funds 


\section{Figure 8}

\section{Size Distribution of Issuers of Different Bond Sizes}

This figure shows the firm size distribution of emerging market issuers and investment grade developed market issuers of international U.S. dollar-denominated bonds of different sizes during the pre-2008 (2000-2008) and post-2008 (2009-2016) periods. Firm size is measured by the log of total assets. The left-side graphs show the cumulative distribution of issuers of international bonds with a face value below $\$ 500$ million (0:500). The right-side graphs show the cumulative distribution of issuers of international bonds with a face value equal to or above $\$ 500$ million [500:1,000). Issuers in each sub-period are defined as firms that issued bonds of a certain size at least once during this period. Densities are estimated using the Epanechnikov kernel function.

Issuers of (0:500) Bonds

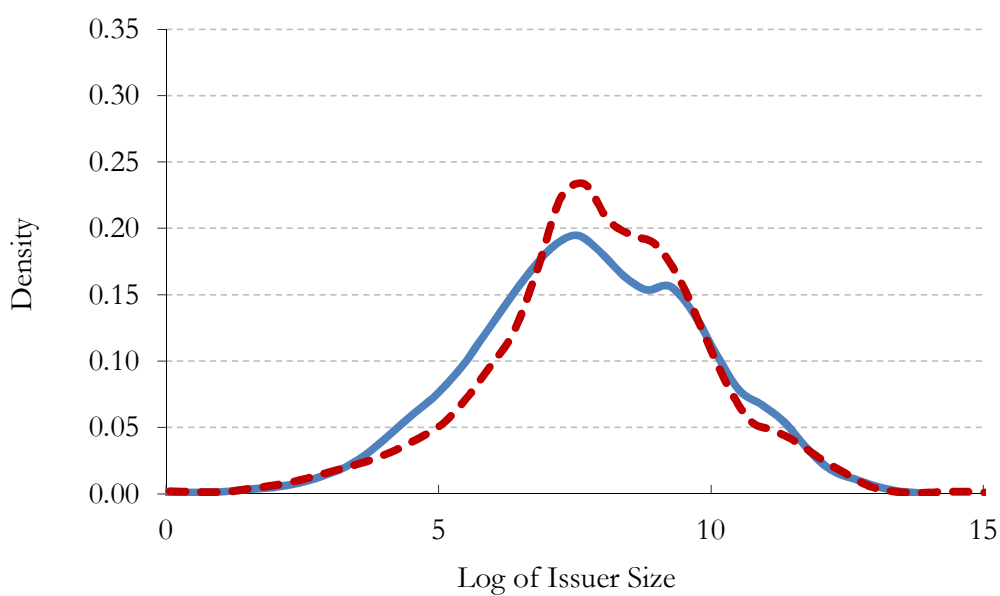

Panel A. Emerging Markets

Issuers of [500:1,000) Bonds

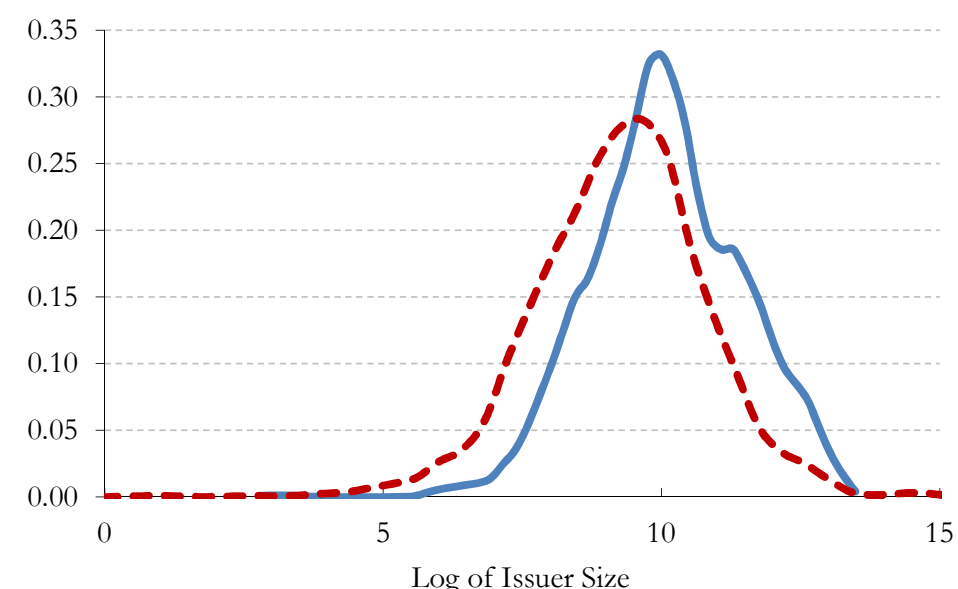

Panel B. Developed Markets
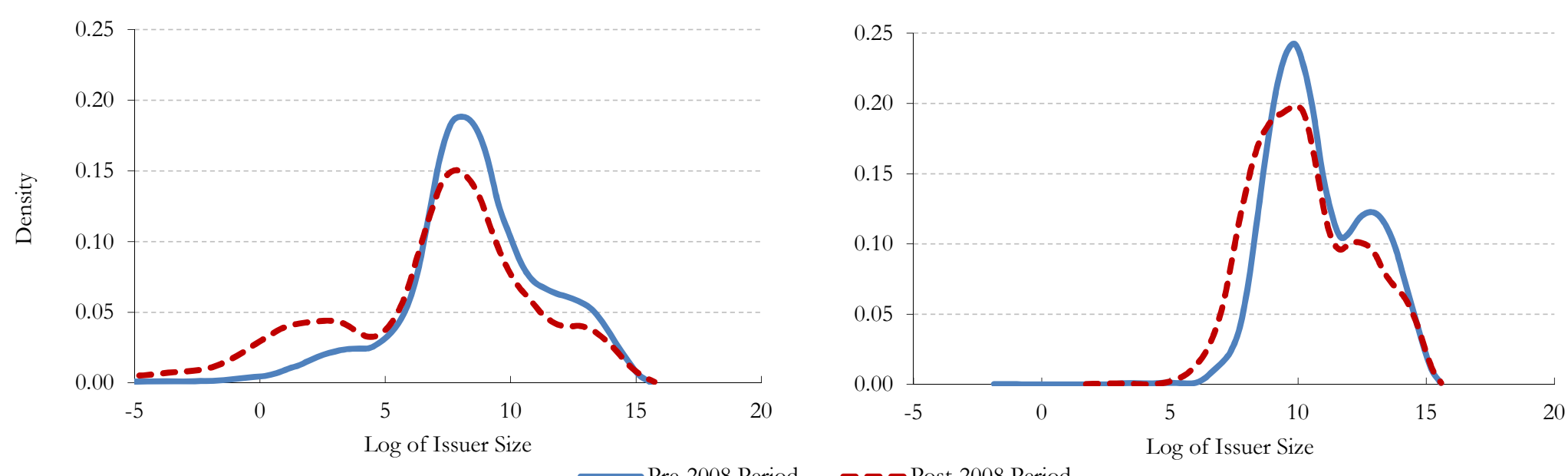


\section{Figure 9}

\section{Probability of Issuing Large U.S. Dollar-Denominated Bonds by Firm Size}

This figure shows the probability of issuing an international U.S. dollar-denominated bond with a face value equal to or above $\$ 500$ million [500:1,000) in the pre-2008 (2000-2008) and post-2008 (2009-2016) periods for firms of different sizes. Firm size is measured by the log of total assets. The sample is restricted to firms that issued at least one bond during 2000-2016. The probabilities are computed from probit and logit regressions reported in Table 9 for the [500:1,000) bond issuance dummy on the pre-2008 dummy, the post-2008 dummy, and the interaction of the pre and post dummy variables with the log of assets. Panel A reports the probabilities computed using the probit regressions. Panel B reports the probabilities computed using the logit regressions. The left-side graphs restrict the sample to firms in emerging markets. The right-side graphs restrict the sample to investment grade firms in developed markets.

\section{Panel A. Probit}

\section{Emerging Markets}

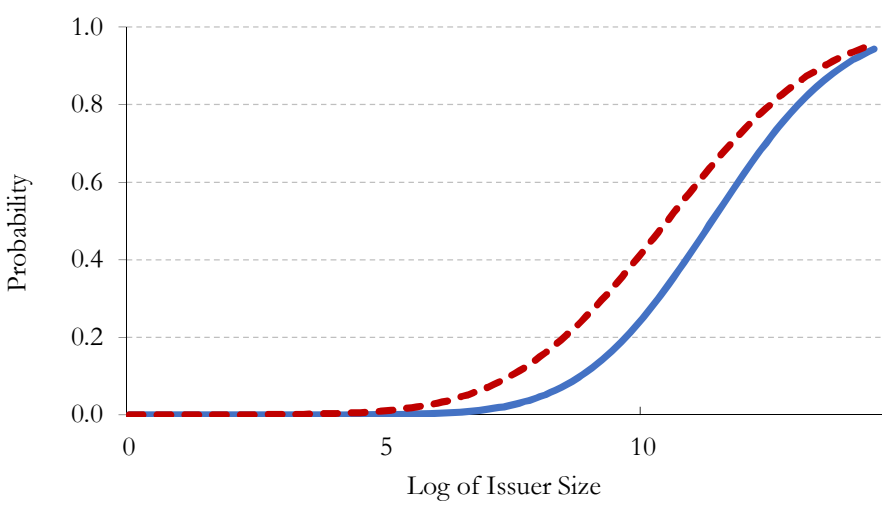

Developed Markets

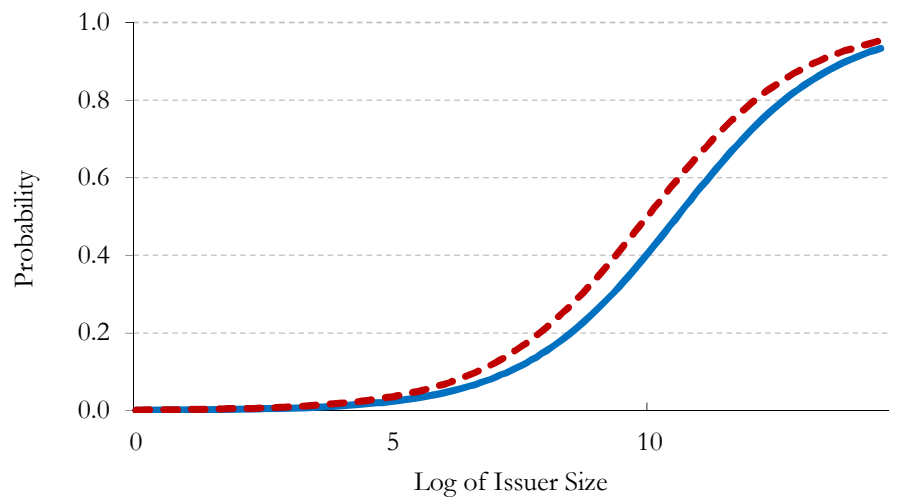

Panel B. Logit
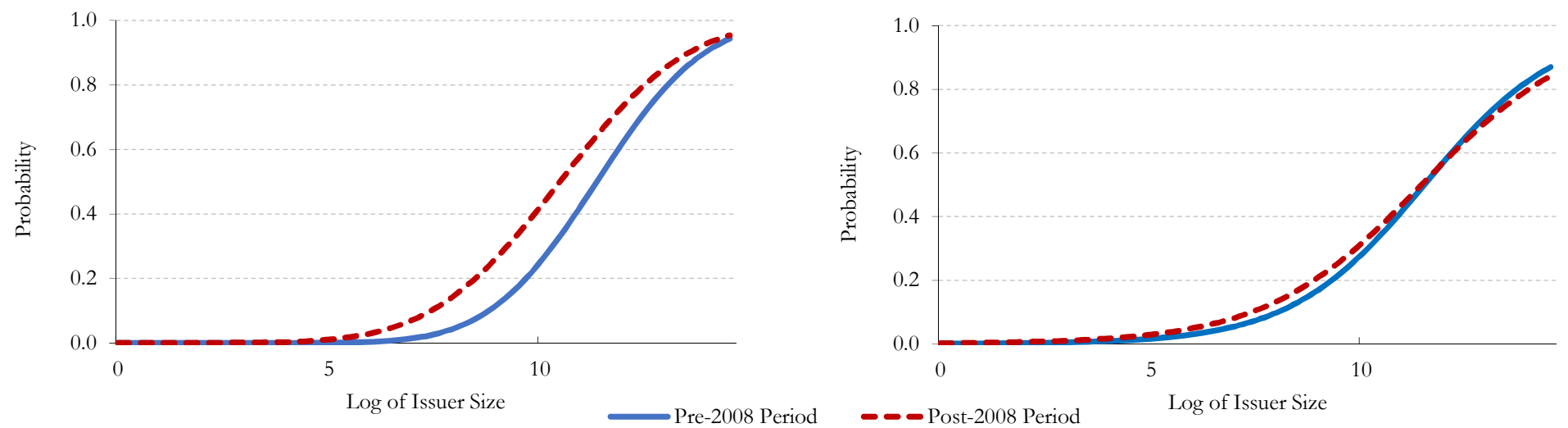
Figure 10

\section{Change in Cash and Short-Term Investments After Bond Issuance}

This figure shows the coefficients of cash and short-term investments from firm-level panel OLS regressions that measure the use of funds for international U.S. dollar-denominated bond issuers two periods after the issuance. Panel A shows the use of funds for emerging market issuers and investment grade developed market issuers of bonds of different sizes during the pre-2008 (2000-2008) and post-2008 (2009-2016) periods. The graph shows the dollar effect separately for issuers of international bonds with a face value below $\$ 500$ million (0:500) and equal to or above $\$ 500$ million [500:1,000). Panel B shows the use of funds for bond issuers in emerging markets during 2009-2016, separately for firms with high assets and low assets. A firm is classified as a "high asset firm" if its average assets during 2009-2016 are equal to or greater than the assets of the median firm in the same country, using only firms that issued bonds equal to or greater than $\$ 500$ million during 2009 -2016. Analogously, "low asset firms" are those below the median firm. The analysis follows the specification of Kim and Weisbach (2008). The dependent variable for year $\mathrm{t}$ is Cash $=\log \left[\left(\left(\mathrm{V}_{\mathrm{n}}-\mathrm{V}_{0}\right) /\right.\right.$ Assets $\left.)+1\right]$, where $\mathrm{V}$ is cash and short-term investments. Independent variables are bond issuance value and other sources of funds, both normalized by total assets, in addition to the log of total assets. Panel A also controls for the contemporaneous growth rate of sales, and the standard deviation of the growth of sales. Total assets are measured at the value of the year just before the issuance. The dollar effect captures the dollar change in the dependent variable two years after the issuance year that results from a one dollar increase in a firm's bond issuance. All variables are winsorized at the $1 \%$ level.

Panel A. Controlling for Growth of Sales and the Standard Deviation of the Growth of Sales

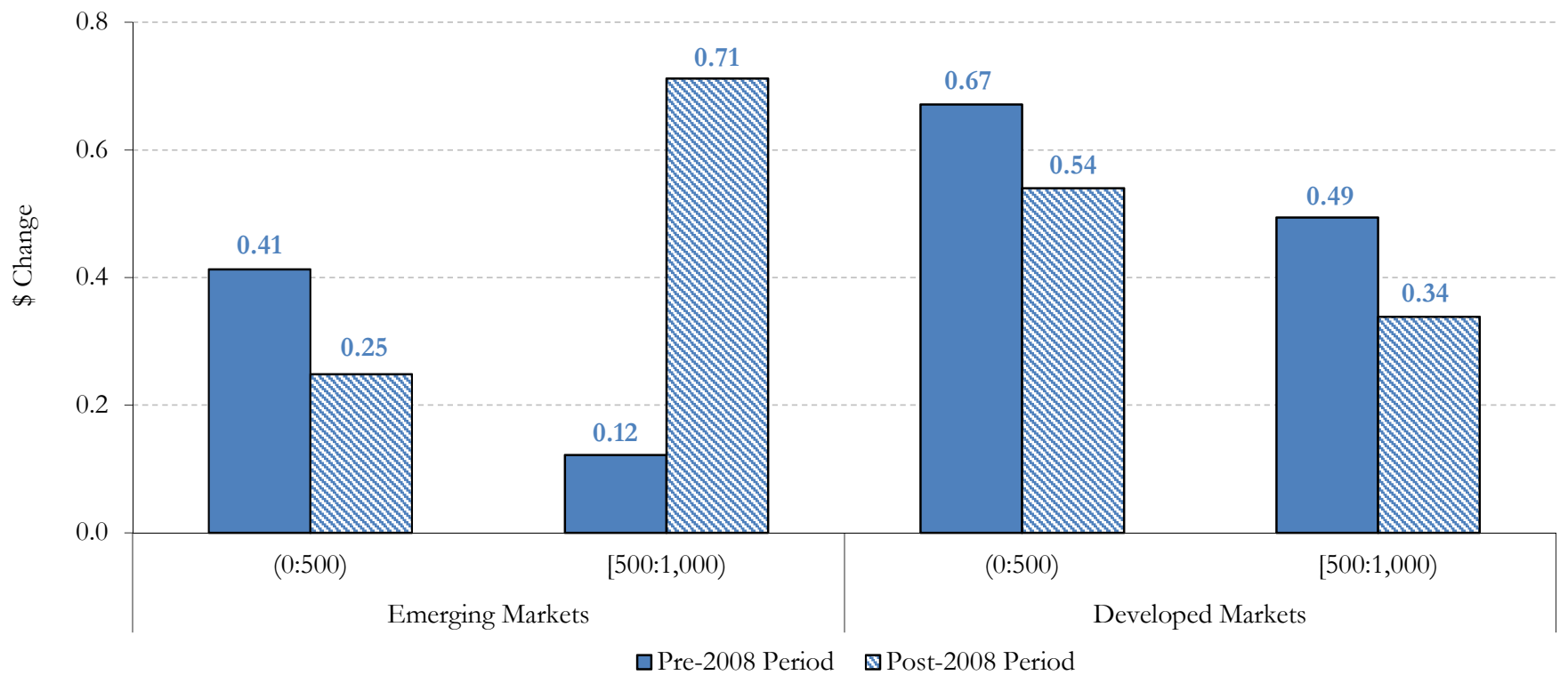

Panel B. High Asset and Low Asset Emerging Market Firms

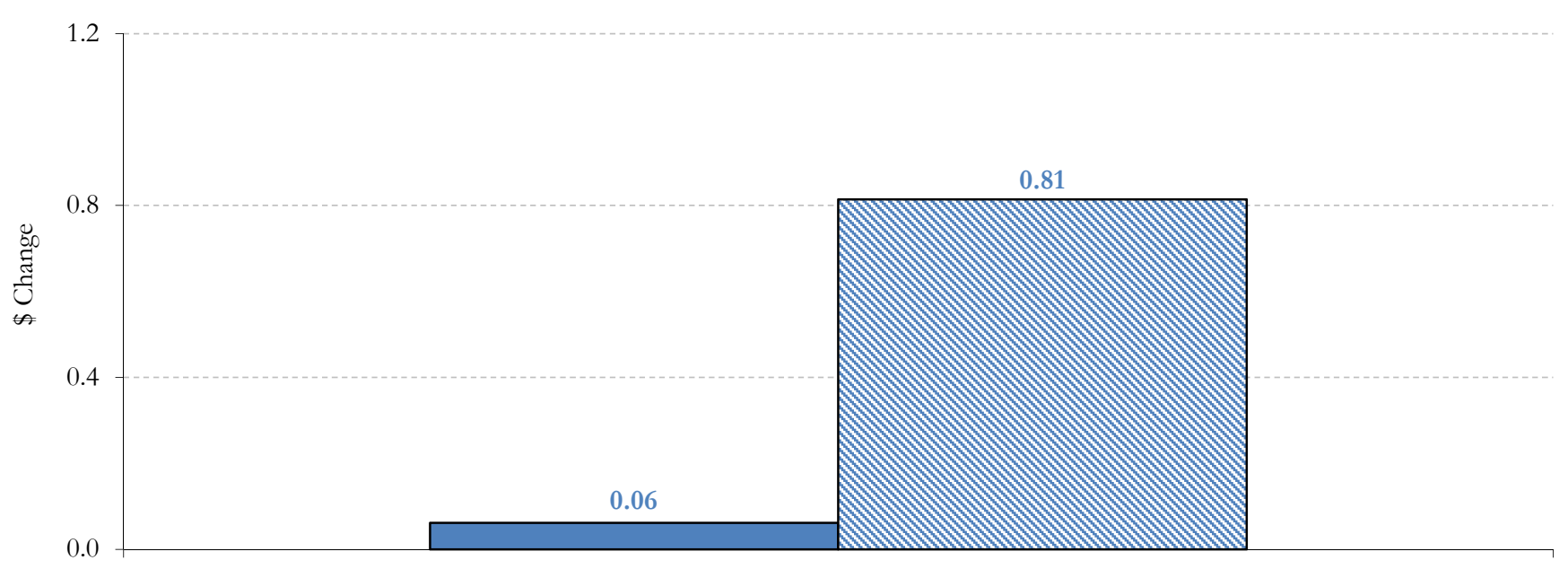

$\square$ High Asset Firms $\quad$ L Low Asset Firms 


\section{Table 1}

\section{Emerging Market Bond Issuances of Different Sizes}

This table reports the percentage of international U.S. dollar-denominated bonds issuances with face value below $\$ 300$ million (0:300), between $\$ 300$ and $\$ 500$ million [300:500), and equal to or above $\$ 500$ million [500:1,000), by firms in emerging markets during the pre-2008 (2000-2008) and post-2008 (2009-2016) periods. Column 1 displays the percentage of the total value of bonds issued in each size category relative to the total value of bonds issued of any size. The value of each bond is in constant 2011 U.S. dollars. Column 2 displays the percentage of the total number of bonds issued in each size category relative to the total number of bonds issued of any size.

(1)

Total Value of Bonds
(2)

\begin{tabular}{lccccc} 
& \multicolumn{2}{c}{ Total Value of Bonds } & & \multicolumn{2}{c}{ Total Number of Bonds } \\
\cline { 2 - 3 } & Pre 2008 & Post 2008 & & Pre 2008 & Post 2008 \\
\hline$(0: 300)$ & $42.86 \%$ & $16.64 \%$ & & $75.41 \%$ & $47.52 \%$ \\
{$[300: 500)$} & $23.99 \%$ & $21.72 \%$ & & $13.41 \%$ & $19.67 \%$ \\
{$[500: 1,000)$} & $33.15 \%$ & $61.64 \%$ & & $11.18 \%$ & $32.81 \%$ \\
\hline
\end{tabular}


Table 2

\section{Yield to Maturity and Probability of Issuing Bonds of Different Sizes, [400:500) and [500:600)}

This table reports mean tests for the yield to maturity and the probability of issuing an international U.S. dollar-denominated bond with face value between $\$ 400$ and $\$ 500$ million [400:500), and between $\$ 500$ and $\$ 600$ million [500:600), for firms in emerging markets and investment grade firms in developed markets during the pre-2008 (2000 2008) and post-2008 (2009-2016) periods. Panel A shows the yield to maturity (in percent) in each category. Panel B shows the percentage of issued bonds. Columns 1-3 show the mean tests and differences (pre and post 2008) for the [400:500) bonds, separately for emerging and developed markets. Columns 4-6 show the mean tests and differences (pre and post 2008) for the [500:600) bonds. Column 7 shows the difference-in-differences effects between columns 3 and 6 for each region. Column 8 reports the triple difference between emerging and developed markets. The yield to maturity variable is winsorized at the $5 \%$ level. *, **, and $* * *$ indicate statistical significance at the $10 \%, 5 \%$, and $1 \%$ levels, respectively.

\begin{tabular}{|c|c|c|c|c|c|c|c|c|}
\hline \multicolumn{9}{|c|}{ Panel A. Yield to Maturity } \\
\hline & \multicolumn{3}{|c|}{$[400: 500)$} & \multicolumn{3}{|c|}{$[500: 600)$} & \multirow{2}{*}{$\begin{array}{l}\text { Diff-in-Diff } \\
(7)=(6)-(3)\end{array}$} & \multirow{2}{*}{$\begin{array}{c}\text { Triple Diff } \\
(8)=\operatorname{EM}(7)-\operatorname{DM}(7)\end{array}$} \\
\hline & $\begin{array}{c}\text { Pre } 2008 \\
\text { (1) }\end{array}$ & $\begin{array}{c}\text { Post } 2008 \\
\text { (2) }\end{array}$ & $\begin{array}{c}\text { Diff } \\
(3)=(2)-(1)\end{array}$ & $\begin{array}{c}\text { Pre } 2008 \\
\text { (4) }\end{array}$ & $\begin{array}{c}\text { Post } 2008 \\
\text { (5) }\end{array}$ & $\begin{array}{c}\text { Diff } \\
(6)=(5)-(4)\end{array}$ & & \\
\hline Emerging Markets & $\begin{array}{r}7.189 \\
(0.232)\end{array}$ & $\begin{array}{r}6.223 \\
(0.189)\end{array}$ & $\begin{array}{l}-0.966 \text { *** } \\
(0.312)\end{array}$ & $\begin{array}{r}7.100 \\
(0.180)\end{array}$ & $\begin{array}{r}4.922 \\
(0.078)\end{array}$ & $\begin{array}{l}-2.177 \text { *** } \\
(0.189)\end{array}$ & $\begin{array}{l}-1.211 \text { *** } \\
(0.333)\end{array}$ & $-0.988 * * *$ \\
\hline Developed Markets & $\begin{array}{r}5.534 \\
(0.077)\end{array}$ & $\begin{array}{r}4.076 \\
(0.075)\end{array}$ & $\begin{array}{l}-1.458 \text { *** } \\
(0.109)\end{array}$ & $\begin{array}{r}5.357 \\
(0.068)\end{array}$ & $\begin{array}{r}3.676 \\
(0.058)\end{array}$ & $\begin{array}{l}-1.681 \text { *** } \\
(0.092)\end{array}$ & $\begin{array}{l}-0.223 \\
(0.147)\end{array}$ & $(0.344)$ \\
\hline \multicolumn{9}{|c|}{ Panel B. Issuance } \\
\hline & \multicolumn{3}{|c|}{$[400: 500)$} & \multicolumn{3}{|c|}{$[500: 600)$} & Diff-in-Diff & Triple Diff \\
\hline & $\begin{array}{c}\text { Pre } 2008 \\
\text { (1) }\end{array}$ & $\begin{array}{c}\text { Post } 2008 \\
(2)\end{array}$ & $\begin{array}{c}\text { Diff } \\
(3)=(2)-(1)\end{array}$ & $\begin{array}{c}\text { Pre } 2008 \\
(4) \\
\end{array}$ & $\begin{array}{c}\text { Post } 2008 \\
(5) \\
\end{array}$ & $\begin{array}{c}\text { Diff } \\
(6)=(5)-(4)\end{array}$ & $(7)=(6)-(3)$ & $(8)=\operatorname{EM}(7)-\mathrm{DM}(7)$ \\
\hline Emerging Markets & $\begin{array}{r}0.043 \\
(0.004)\end{array}$ & $\begin{array}{r}0.063 \\
(0.005)\end{array}$ & $\begin{array}{l}0.020 \text { *** } \\
(0.006)\end{array}$ & $\begin{array}{r}0.065 \\
(0.005)\end{array}$ & $\begin{array}{r}0.188 \\
(0.008)\end{array}$ & $\begin{array}{l}0.123 \text { *** } \\
(0.009)\end{array}$ & $\begin{array}{l}0.103 \text { *** } \\
(0.011)\end{array}$ & $0.072 * * *$ \\
\hline Developed Markets & $\begin{array}{r}0.043 \\
(0.002)\end{array}$ & $\begin{array}{r}0.047 \\
(0.003)\end{array}$ & $\begin{array}{r}0.004 \\
(0.003)\end{array}$ & $\begin{array}{r}0.074 \\
(0.003)\end{array}$ & $\begin{array}{r}0.110 \\
(0.004)\end{array}$ & $\begin{array}{l}0.035^{* * *} \\
(0.005)\end{array}$ & $\begin{array}{l}0.031 \text { *** } \\
(0.006)\end{array}$ & $(0.013)$ \\
\hline
\end{tabular}


Table 3

Yield to Maturity and Issuance Sizes

This table reports difference-in-difference regressions of the yield to maturity of international U.S. dollardenominated bonds of different sizes in millions of U.S. dollars, measuring the relative change after 2008 for firms in emerging markets (EM) compared to investment grade firms in developed markets. The analysis is restricted to positive bond issuance observations during 2000-2016 and includes both emerging market and investment grade developed market issuers. The full equation estimated is Equation (7) in the text. Columns 1-4 report the coefficients $\beta_{X}^{E M, P o s t}$ of the interaction term between the dummy of each bucket size, the post 2008 dummy (equal to one for 2009-2016) and the emerging market dummy. The coefficients $\beta_{X}^{D M}, \beta_{X}^{D M, P o s t}$, and $\beta_{X}^{E M}$ are estimated but are not reported in this table to conserve space. They are reported instead in Appendix Table 5 and Appendix Table 6. Column 2 includes country, industry-year, and quarter-year fixed effects (FE). Column 3 includes country, industry-year, maturity, rating, quarter-year fixed effects, in addition to bond-firm controls. Bond-firm controls include a dummy indicating whether the bond was issued publicly or privately, a dummy indicating whether the firm is foreign-owned, a dummy indicating whether the firm has partial government ownership, and a fixed or flexible coupon dummy. Column 4 reports a placebo test using nonindex-eligible bonds, which are those with less than five years of maturity or flexible coupon rates. Standard errors are clustered at the country and quarter-year levels. The yield to maturity variable is winsorized at the $5 \%$ level. $*, * *$, and $* * *$ indicate statistical significance at the $10 \%, 5 \%$, and $1 \%$ levels, respectively.

\begin{tabular}{|c|c|c|c|c|c|}
\hline & \multirow{2}{*}{$\begin{array}{l}\text { Associated } \\
\text { Coefficients }\end{array}$} & \multicolumn{4}{|c|}{ Dependent Variable: Yield to Maturity } \\
\hline & & (1) & (2) & (3) & (4) \\
\hline $\mathrm{EM}^{*}[100: 200) *$ Post 2008 & $\beta_{100}^{E M, \text { Post }}$ & $\begin{array}{l}-0.778 \\
(0.619)\end{array}$ & $\begin{array}{l}-0.161 \\
(0.425)\end{array}$ & $\begin{array}{r}0.469 \\
(0.340)\end{array}$ & $\begin{array}{l}-0.537 \\
(1.417)\end{array}$ \\
\hline $\mathrm{EM}^{*}[200: 300) *$ Post 2008 & $\beta_{200}^{E M, \text { Post }}$ & $\begin{array}{r}0.27 \\
(0.261)\end{array}$ & $\begin{array}{r}0.339 \\
(0.301)\end{array}$ & $\begin{array}{l}0.863 \text { *** } \\
(0.305)\end{array}$ & $\begin{array}{r}0.965 \\
(0.653)\end{array}$ \\
\hline $\mathrm{EM}^{*}[300: 400) *$ Post 2008 & $\beta_{300}^{E M, P o s t}$ & $\begin{array}{l}-0.034 \\
(0.235)\end{array}$ & $\begin{array}{l}-0.293 \\
(0.277)\end{array}$ & $\begin{array}{c}0.435 * \\
(0.253)\end{array}$ & $\begin{array}{l}-0.575 \\
(0.821)\end{array}$ \\
\hline $\mathrm{EM}^{*}[400: 500) *$ Post 2008 & $\beta_{400}^{E M, P o s t}$ & $\begin{array}{r}0.492 \\
(0.366)\end{array}$ & $\begin{array}{l}0.872 \text { ** } \\
(0.366)\end{array}$ & $\begin{array}{l}1.154 \text { *** } \\
(0.339)\end{array}$ & $\begin{array}{r}0.052 \\
(0.560)\end{array}$ \\
\hline $\mathrm{EM}^{*}[500: 600) *$ Post 2008 & $\beta_{500}^{E M, \text { Post }}$ & $\begin{array}{l}-0.496 \text { *** } \\
(0.153)\end{array}$ & $\begin{array}{l}-0.052 \\
(0.409)\end{array}$ & $\begin{array}{r}0.397 \\
(0.308)\end{array}$ & $\begin{array}{l}-0.228 \\
(0.985)\end{array}$ \\
\hline $\mathrm{EM}^{*}[600: 700) *$ Post 2008 & $\beta_{600}^{E M, \text { Post }}$ & $\begin{array}{c}0.915 * \\
(0.516)\end{array}$ & $\begin{array}{r}0.588 \\
(0.513)\end{array}$ & $\begin{array}{r}0.516 \\
(0.454)\end{array}$ & $\begin{array}{l}-0.560 \\
(1.044)\end{array}$ \\
\hline $\mathrm{EM}^{*}[700: 800) *$ Post 2008 & $\beta_{700}^{E M, \text { Post }}$ & $\begin{array}{c}0.820 \text { ** } \\
(0.380)\end{array}$ & $\begin{array}{r}0.176 \\
(0.586)\end{array}$ & $\begin{array}{r}0.531 \\
(0.451)\end{array}$ & $\begin{array}{l}2.941 \text { *** } \\
(0.509)\end{array}$ \\
\hline $\mathrm{EM}^{*}[800: 900) *$ Post 2008 & $\beta_{800}^{E M, \text { Post }}$ & $\begin{array}{r}0.752 \\
(0.540)\end{array}$ & $\begin{array}{r}0.850 \\
(0.983)\end{array}$ & $\begin{array}{c}1.275 * \\
(0.645)\end{array}$ & $\begin{array}{l}1.996 \text { *** } \\
(0.547)\end{array}$ \\
\hline Bond Controls & & No & No & Yes & No \\
\hline Country FE & & No & Yes & Yes & No \\
\hline Industry-Year FE & & No & Yes & Yes & No \\
\hline Maturity FE & & No & No & Yes & No \\
\hline Ratings FE & & No & No & Yes & No \\
\hline Quarter-Year FE & & No & Yes & Yes & No \\
\hline Diff-in-Diff & $\beta_{500}^{E M, \text { Post }}-\beta_{400}^{E M, \text { Post }}$ & $-0.988 * * *$ & $-0.924 * *$ & $-0.757 * *$ & -0.280 \\
\hline P-Value & & 0.002 & 0.021 & 0.029 & 0.823 \\
\hline Number of Observations & & 7,939 & 7,939 & 7,818 & 1,600 \\
\hline $\mathrm{R}^{2}$ & & 0.344 & 0.659 & 0.763 & 0.471 \\
\hline
\end{tabular}




\section{Table 4}

\section{Probability of Issuing Bonds of Different Sizes}

This table reports difference-in-difference regressions of the change in the probability of issuing an international U.S. dollar-denominated bond of a certain size in millions of U.S. dollars, pre and post 2008, for firms in emerging markets (EM) relative to investment grade firms in developed markets. The analysis is restricted to positive bond issuance observations during 2000-2016. Panel A reports the regressions for the probability of issuing a bond of a certain size as a dependent variable on the interaction of the post 2008 dummy (equal to one for 2009-2016) with the emerging market dummy. The regressions include country, industry and quarter-year fixed effects (FE). Panel B reports the same regression as in Panel A, but including maturity and rating fixed effects, in addition to bond-firm controls. Bond-firm controls include a dummy indicating whether the bond was issued publicly or privately, a dummy indicating whether the firm is foreignowned, a dummy indicating whether the firm has partial government ownership, and a fixed or flexible coupon dummy. Standard errors are clustered at the country and quarter-year levels. *, **, and *** indicate statistical significance at the 10\%, 5\%, and 1\% levels, respectively.

Panel A. Dependent Variable: Dummy $=1$ if Issuance $=[X: X+100)$

\begin{tabular}{|c|c|c|c|c|c|c|c|c|c|}
\hline & \multicolumn{9}{|c|}{ Probability of Issuing Debt of a Certain Amount } \\
\hline & (1) & $(2)$ & (3) & (4) & (5) & $(6)$ & $(7)$ & (8) & $(9)$ \\
\hline & $(0: 100)$ & {$[100: 200)$} & {$[200: 300)$} & {$[300: 400)$} & {$[400: 500)$} & {$[500: 600)$} & {$[600: 700)$} & {$[700: 800)$} & {$[800: 900)$} \\
\hline \multirow[t]{2}{*}{ EM*Post 2008} & -0.090 & $-0.075 * *$ & -0.012 & $0.038 * *$ & 0.015 & $0.090 * * *$ & -0.001 & 0.019 & 0.012 \\
\hline & $(0.056)$ & $(0.029)$ & $(0.020)$ & $(0.015)$ & $(0.016)$ & $(0.023)$ & $(0.009)$ & $(0.012)$ & $(0.009)$ \\
\hline Bond Controls & No & No & No & No & No & No & No & No & No \\
\hline Country FE & Yes & Yes & Yes & Yes & Yes & Yes & Yes & Yes & Yes \\
\hline Industry FE & Yes & Yes & Yes & Yes & Yes & Yes & Yes & Yes & Yes \\
\hline Quarter-Year FE & Yes & Yes & Yes & Yes & Yes & Yes & Yes & Yes & Yes \\
\hline Mean Probability & 0.359 & 0.173 & 0.127 & 0.0908 & 0.0471 & 0.101 & 0.0296 & 0.0491 & 0.0157 \\
\hline Number of Countries & 68 & 68 & 68 & 68 & 68 & 68 & 68 & 68 & 68 \\
\hline Number of Observations & 19,905 & 19,905 & 19,905 & 19,905 & 19,905 & 19,905 & 19,905 & 19,905 & 19,905 \\
\hline $\mathrm{R}^{2}$ & 0.218 & 0.0701 & 0.0457 & 0.0539 & 0.0407 & 0.0624 & 0.0371 & 0.0463 & 0.0271 \\
\hline
\end{tabular}

Panel B. Dependent Variable: Dummy $=1$ if Issuance $=[X: X+100)$

\begin{tabular}{|c|c|c|c|c|c|c|c|c|c|}
\hline & \multicolumn{9}{|c|}{ Probability of Issuing Debt of a Certain Amount } \\
\hline & (1) & (2) & (3) & (4) & (5) & $(6)$ & (7) & $(8)$ & $(9)$ \\
\hline & $(0: 100)$ & {$[100: 200)$} & {$[200: 300)$} & {$[300: 400)$} & {$[400: 500)$} & {$[500: 600)$} & {$[600: 700)$} & {$[700: 800)$} & {$[800: 900)$} \\
\hline \multirow[t]{2}{*}{ EM*Post 2008} & -0.074 & $-0.076 * *$ & -0.009 & $0.037 * *$ & 0.014 & $0.084 * * *$ & -0.003 & 0.013 & 0.011 \\
\hline & $(0.058)$ & $(0.029)$ & $(0.019)$ & $(0.015)$ & $(0.016)$ & $(0.024)$ & $(0.009)$ & $(0.013)$ & $(0.009)$ \\
\hline Bond Controls & Yes & Yes & Yes & Yes & Yes & Yes & Yes & Yes & Yes \\
\hline Country FE & Yes & Yes & Yes & Yes & Yes & Yes & Yes & Yes & Yes \\
\hline Industry FE & Yes & Yes & Yes & Yes & Yes & Yes & Yes & Yes & Yes \\
\hline Maturity FE & Yes & Yes & Yes & Yes & Yes & Yes & Yes & Yes & Yes \\
\hline Quarter-Year FE & Yes & Yes & Yes & Yes & Yes & Yes & Yes & Yes & Yes \\
\hline Rating FE & Yes & Yes & Yes & Yes & Yes & Yes & Yes & Yes & Yes \\
\hline Mean Probability & 0.359 & 0.173 & 0.127 & 0.0908 & 0.0471 & 0.101 & 0.0296 & 0.0491 & 0.0157 \\
\hline Number of Countries & 68 & 68 & 68 & 68 & 68 & 68 & 68 & 68 & 68 \\
\hline Number of Observations & 19,724 & 19,724 & 19,724 & 19,724 & 19,724 & 19,724 & 19,724 & 19,724 & 19,724 \\
\hline $\mathrm{R}^{2}$ & 0.264 & 0.0734 & 0.0471 & 0.0553 & 0.0429 & 0.0853 & 0.0448 & 0.0660 & 0.0327 \\
\hline
\end{tabular}




\section{Table 5}

\section{Placebo Test: Probability of Issuing Non-Index-Eligible Bonds of Different Sizes}

This table reports difference-in-difference regressions of the change in the probability of issuing an international U.S. dollardenominated bond of a certain size in millions of U.S. dollars, pre and post 2008, for firms in emerging markets (EM) relative to investment grade firms in developed markets. The analysis is restricted to positive bond issuance observations during 2000-2016. The table reports the regressions for the bond issuance dummy of each size bucket on the interaction of the post 2008 dummy (equal to one for 2009-2016) with the emerging market dummy. As opposed to the results in Table 4, the regressions in this table use only nonindex-eligible bonds, which are those with less than five years of maturity or flexible interest rates. All regressions include country, industry, and quarter-year fixed effects (FE). Standard errors are clustered at the country and quarter-year levels. *, **, and $* * *$ indicate statistical significance at the $10 \%, 5 \%$, and $1 \%$ levels, respectively.

Dependent Variable: Dummy $=1$ if Issuance $=[X: X+100)$

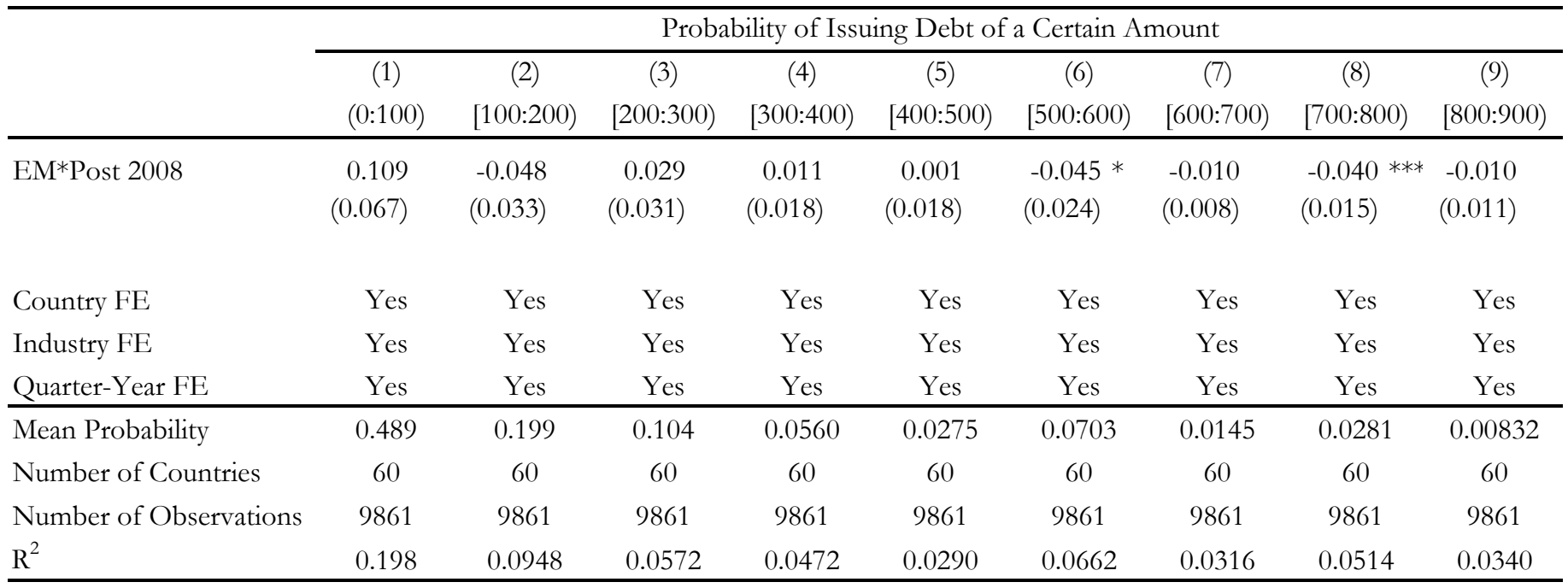




\section{Table 6}

\section{Probability of Issuing $\$ 500$ Million Bonds and the Carry Trade}

This table reports linear regressions of the probability of issuing an international U.S. dollardenominated bond on the log of one plus the lagged carry trade measure for firms in emerging markets during 2009-2016. The estimations include only issuances of bonds of less than or equal to $\$ 500$ million in face value. The carry trade measure is the difference between the interest rate in the money market in local currency and the U.S. money market rate, divided by the annual volatility of the exchange rate during the previous quarter. The regression in column 1 includes quarter-year fixed effects (FE). The regression in column 2 includes industry and quarter-year fixed effects. The regressions in columns 3 and 4 include maturity controls and industry, rating, and quarter-year fixed effects. Maturity controls use the maturity in years of each bond, measured as the number of years to final maturity. Standard errors are clustered at the country and time levels. Standard errors are clustered at the country and quarter-year level. *,**, and *** indicate statistical significance at the $10 \%, 5 \%$, and $1 \%$ levels, respectively.

\begin{tabular}{lcccc}
\hline & \multicolumn{4}{c}{ Dependent Variable: Dummy=1 if Issuance=500 } \\
\cline { 2 - 5 } & $(1)$ & $(2)$ & $(3)$ & $(4)$ \\
\hline $\log (1+$ Lagged Carry Trade) & $0.023 * * *$ & $0.052 * * *$ & $0.055^{* * *}$ & 0.093 *** \\
& $(0.005)$ & $(0.012)$ & $(0.012)$ & $(0.014)$ \\
Maturity controls & No & No & Yes & Yes \\
Industry FE & No & Yes & Yes & Yes \\
Rating FE & No & No & No & Yes \\
Quarter-Year FE & Yes & Yes & Yes & Yes \\
\hline Number of Observations & 1,331 & 1,322 & 1,286 & 1,284 \\
$\mathrm{R}^{2}$ & 0.043 & 0.103 & 0.108 & 0.172 \\
\hline
\end{tabular}




\section{Table 7}

\section{Number, Size, and Portfolio Composition of Debt Mutual Funds}

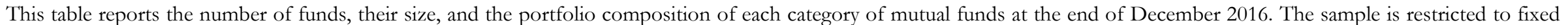

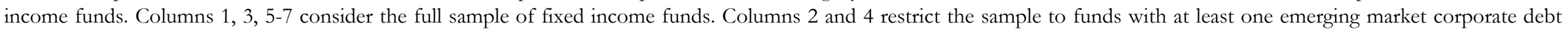

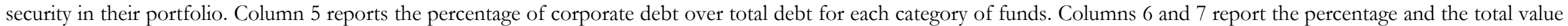

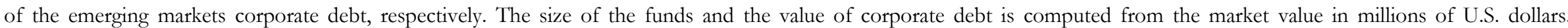

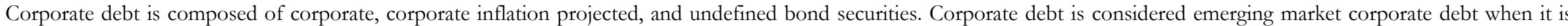
issued by an emerging market firm.

\begin{tabular}{|c|c|c|c|c|c|c|c|}
\hline & \multicolumn{2}{|c|}{ Number of Funds } & \multicolumn{2}{|c|}{ Fund Size } & \multicolumn{2}{|c|}{ Corporate Debt } & \multirow[b]{2}{*}{$\begin{array}{c}\text { Emerging } \\
\text { Market } \\
\text { Corporate } \\
\text { Debt }\end{array}$} \\
\hline & All Funds & $\begin{array}{c}\text { With } \\
\text { Emerging } \\
\text { Market } \\
\text { Corporate } \\
\text { Debt }\end{array}$ & All Funds & $\begin{array}{c}\text { With } \\
\text { Emerging } \\
\text { Market } \\
\text { Corporate } \\
\text { Debt }\end{array}$ & All & $\begin{array}{c}\text { Emerging } \\
\text { Market }\end{array}$ & \\
\hline & $(1)$ & (2) & (3) & (4) & (5) & (6) & $(7)=(3) *(6)$ \\
\hline \multicolumn{8}{|l|}{ Cross-Over Funds } \\
\hline Developed Markets & 895 & 580 & $4,201,066$ & $3,456,386$ & $33.56 \%$ & $1.75 \%$ & 73,712 \\
\hline Emerging Market Sovereign & 315 & 265 & 278,354 & 273,884 & $21.78 \%$ & $16.22 \%$ & 45,156 \\
\hline Emerging Market Mixed & 129 & 101 & 49,045 & 41,259 & $26.74 \%$ & $19.49 \%$ & 9,560 \\
\hline \multicolumn{8}{|l|}{ Emerging Market Specialists Funds } \\
\hline Emerging Market Corporate Specialis & 96 & 91 & 32,593 & 32,364 & $87.66 \%$ & $63.86 \%$ & 20,815 \\
\hline All & 1,435 & 1,037 & $4,561,058$ & $3,803,894$ & $33.15 \%$ & $3.27 \%$ & 149,249 \\
\hline
\end{tabular}


Table 8

\section{Portfolio Composition by Issuance Size of Debt Mutual Funds: Holdings in International U.S. Dollar-Denominated Bonds}

This table reports the percentage of emerging market corporate debt of a certain size interval over the total value of emerging market corporate debt issued of any size that the mean fund of each category held in its portfolio at the end of December 2016 . The analysis is restricted to fixed income funds and to international U.S. dollar-denominated bonds. Columns 1, 2, and 3 report the percentage of emerging market corporate bonds issued with face values below $\$ 300$ million (0:300), between $\$ 300$ and $\$ 500$ million [300:500), and equal to or above $\$ 500$ million [500:1,000), respectively. Corporate emerging market debt is composed of corporate, corporate inflation projected, and undefined bond securities issued by an emerging market firm. Column 4 reports the differences in means tests for bond issuances with a face value equal to or above $\$ 500$ million for each type of funds with respect to the emerging market corporate funds. Column 5 reports the difference in the share of the portfolio in each bucket size for each category of funds with respect to the total amount outstanding. The total amount outstanding is the U.S. dollar-denominated outstanding value of all the international corporate emerging market bonds included in Thomson Reuters Security Data Corporation Platinum database (SDC Platinum) at the end of 2016 .

\begin{tabular}{|c|c|c|c|c|c|}
\hline & \multicolumn{3}{|c|}{ Total Value of Emerging Market Corporate Debt } & \multicolumn{2}{|c|}{ Differences } \\
\hline & $(0: 300)$ & [300:500) & {$[500: 1,000)$} & $\begin{array}{l}\text { Compared to EM } \\
\text { Specialists }\end{array}$ & $\begin{array}{c}\text { Compared to } \\
\text { Outstanding } \\
\text { Amount }\end{array}$ \\
\hline & (1) & (2) & (3) & (4) & $(5)$ \\
\hline \multicolumn{6}{|l|}{ Cross-Over Funds } \\
\hline Developed Markets & $\begin{array}{l}6.70 \% \\
(19.157)\end{array}$ & $\begin{array}{l}10.73 \% \\
(22.718)\end{array}$ & $\begin{array}{l}82.57 \% \\
(28.686)\end{array}$ & $\begin{array}{l}-13.540 \text { *** } \\
(2.469)\end{array}$ & 14.420 \\
\hline Emerging Market Sovereign & $\begin{array}{l}6.31 \% \\
(12.163)\end{array}$ & $\begin{array}{l}15.45 \% \\
(19.719)\end{array}$ & $\begin{array}{l}78.24 \% \\
(22.901)\end{array}$ & $\begin{array}{l}-9.209 * * * \\
(2.660)\end{array}$ & 10.089 \\
\hline Emerging Market Mixed & $\begin{array}{r}7.40 \% \\
(15.371)\end{array}$ & $\begin{array}{l}18.29 \% \\
(18.557)\end{array}$ & $\begin{array}{r}74.31 \% \\
(23.230)\end{array}$ & $\begin{array}{l}-5.284 \\
(3.261)\end{array}$ & 6.164 \\
\hline \multicolumn{6}{|l|}{ Emerging Market Specialists Funds } \\
\hline Emerging Market Corporate Specialists & $\begin{array}{r}6.32 \\
(9.071)\end{array}$ & $\begin{array}{r}24.65 \\
(15.520)\end{array}$ & $\begin{array}{r}69.03 \\
(18.690)\end{array}$ & - & 0.880 \\
\hline Total Amount Outstanding & $12.41 \%$ & $19.44 \%$ & $68.15 \%$ & & - \\
\hline
\end{tabular}




\section{Table 9}

\section{Probability of Issuing Large U.S. Dollar-Denominated Bonds}

This table reports the probit and logit regressions of the change in the probability of issuing an international U.S. dollar-denominated bond with a face value equal to or above $\$ 500$ million [500:1,000) in the pre-2008 (2000-2008) and post-2008 (2009-2016) periods, for firms in emerging markets and investment grade firms in developed markets. The data are aggregated by firm and sub-period (pre2008 and post-2008) level. The sample is restricted to firms that issued at least one bond during 2000-2016. Panel A report regression coefficients for the [500:1,000) bond issuance dummy on the pre-2008 dummy, the post-2008 dummy, and the interaction of the pre and post dummy variables with the log of assets. Assets are computed as the mean value per firm and sub-period. Columns 1 and 2 report the probit regressions. Columns 3 and 4 report the logit regressions. Panel B reports the marginal effects for the increase in the probability of issuing [500:1,000) bonds after 2008 for firms in the $10^{\text {th }}, 25^{\text {th }}, 50^{\text {th }}, 75^{\text {th }}, 90^{\text {th }}, 95^{\text {th }}$, and $99^{\text {th }}$ percentiles of the size distribution. Robust standard errors are reported. *, **, and *** indicate statistical significance at the 10\%, 5\%, and 1\% levels, respectively.

\section{Panel A. Coefficients}

\section{Dependent Variable: Dummy $=1$ if Issuance $=[500: 1,000)$}

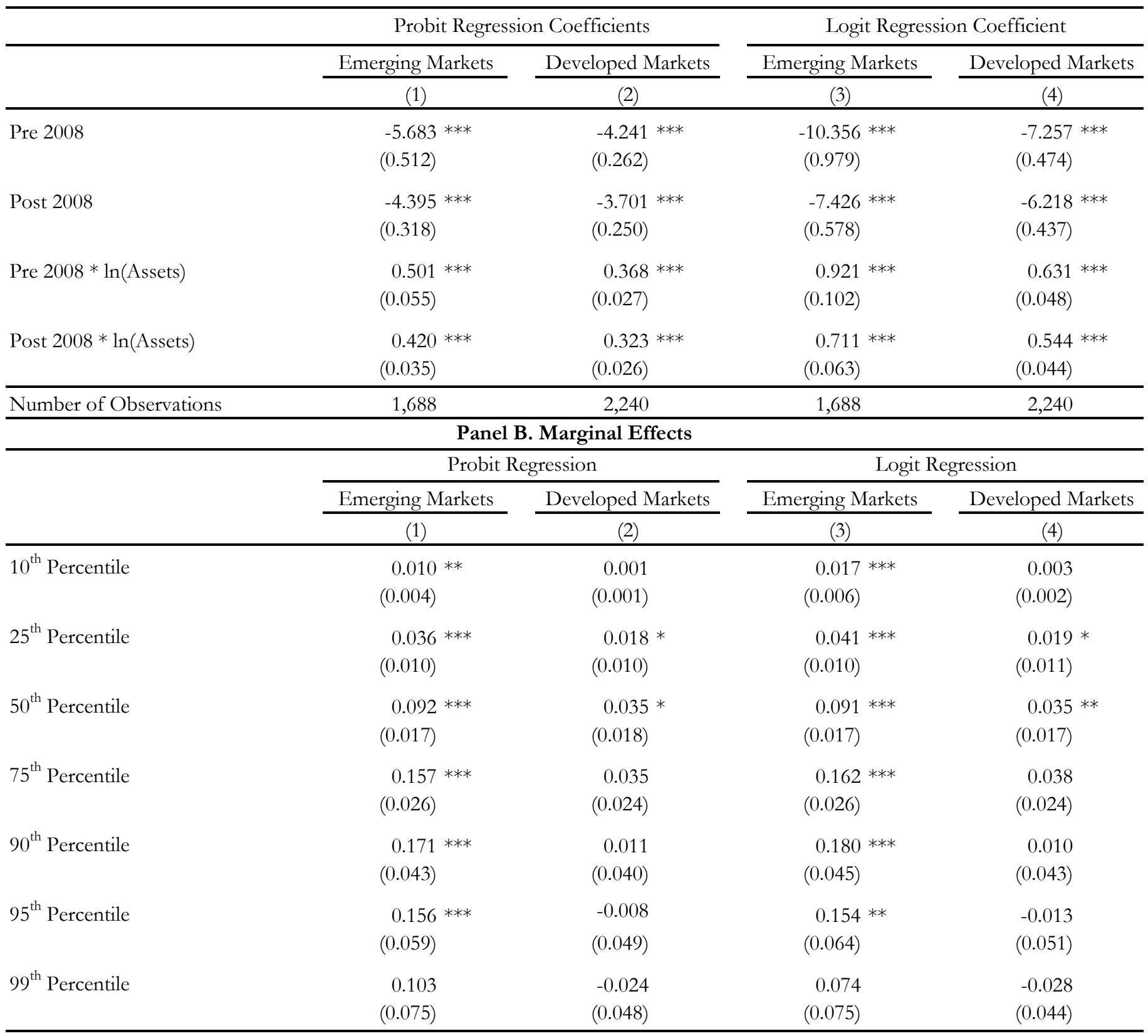




\section{Appendix Figure 1 \\ Assets Benchmarked to J.P. Morgan Emerging Market Debt Indexes}

This figure shows the evolution of the assets of funds that track their performance against J.P. Morgan's emerging market debt indexes during 2007-2018. Numbers are in billions of U.S. dollars. CEMBI stands for Corporate Emerging Market Bond Index, EMBI stands for Emerging Market Bond Index, and GBI stands for Government Bond Index.

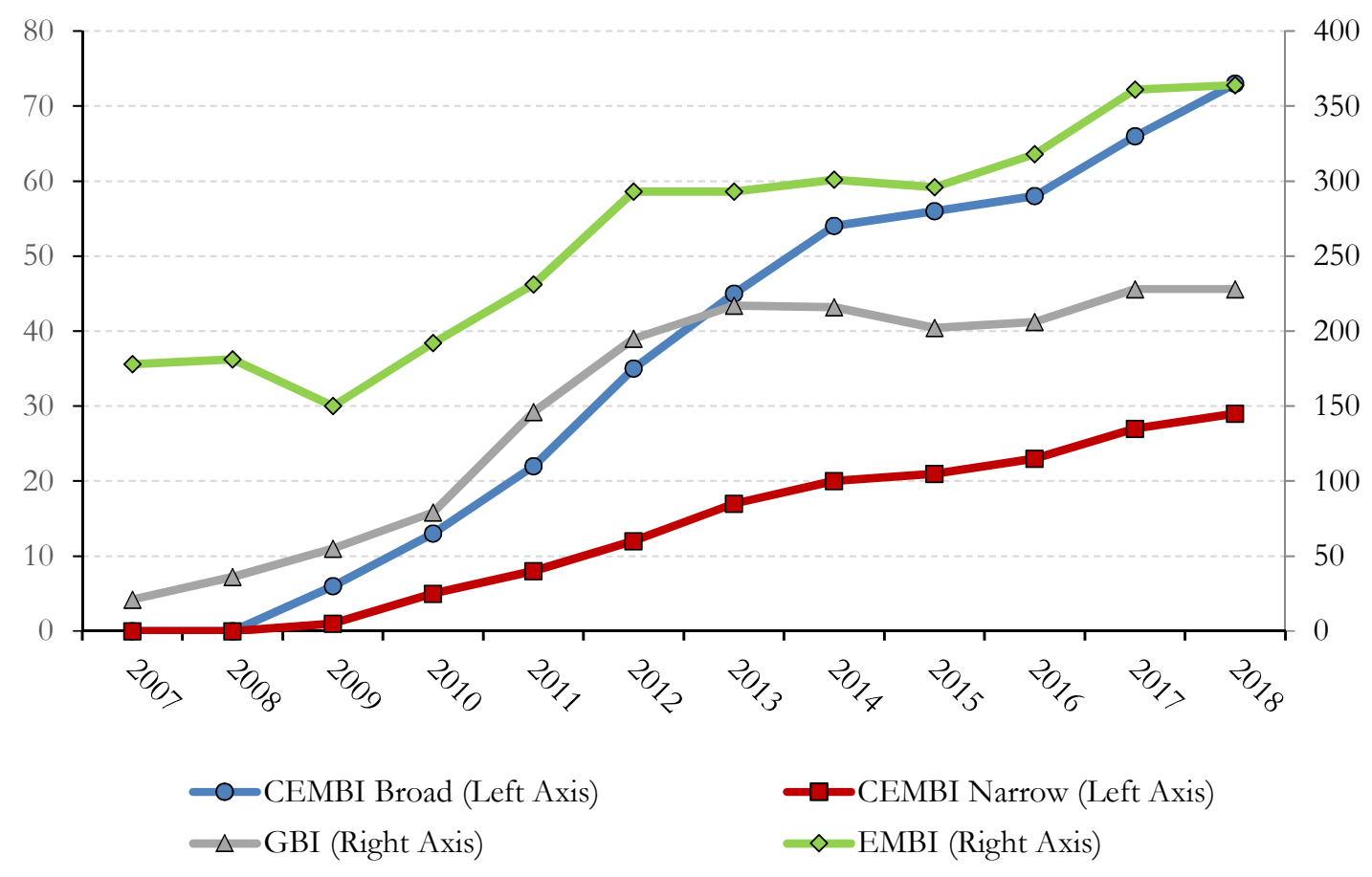




\section{Appendix Figure 2}

Yield to Maturity of Issuances, Pre and Post 2008

\section{Including High-Yield Developed Market Bonds in the Emerging Market Sample}

This figure shows the average yield to maturity (Panel A) and the cumulative distribution (Panel B) of international U.S. dollar-denominated bonds of different issuance sizes in millions of U.S. dollars, for emerging market issuers and high-yield developed market issuers during the pre-2008 (2000-2008) and post-2008 (2009-2016) periods.

Panel A. Yield to Maturity of Issuances, Pre and Post 2008

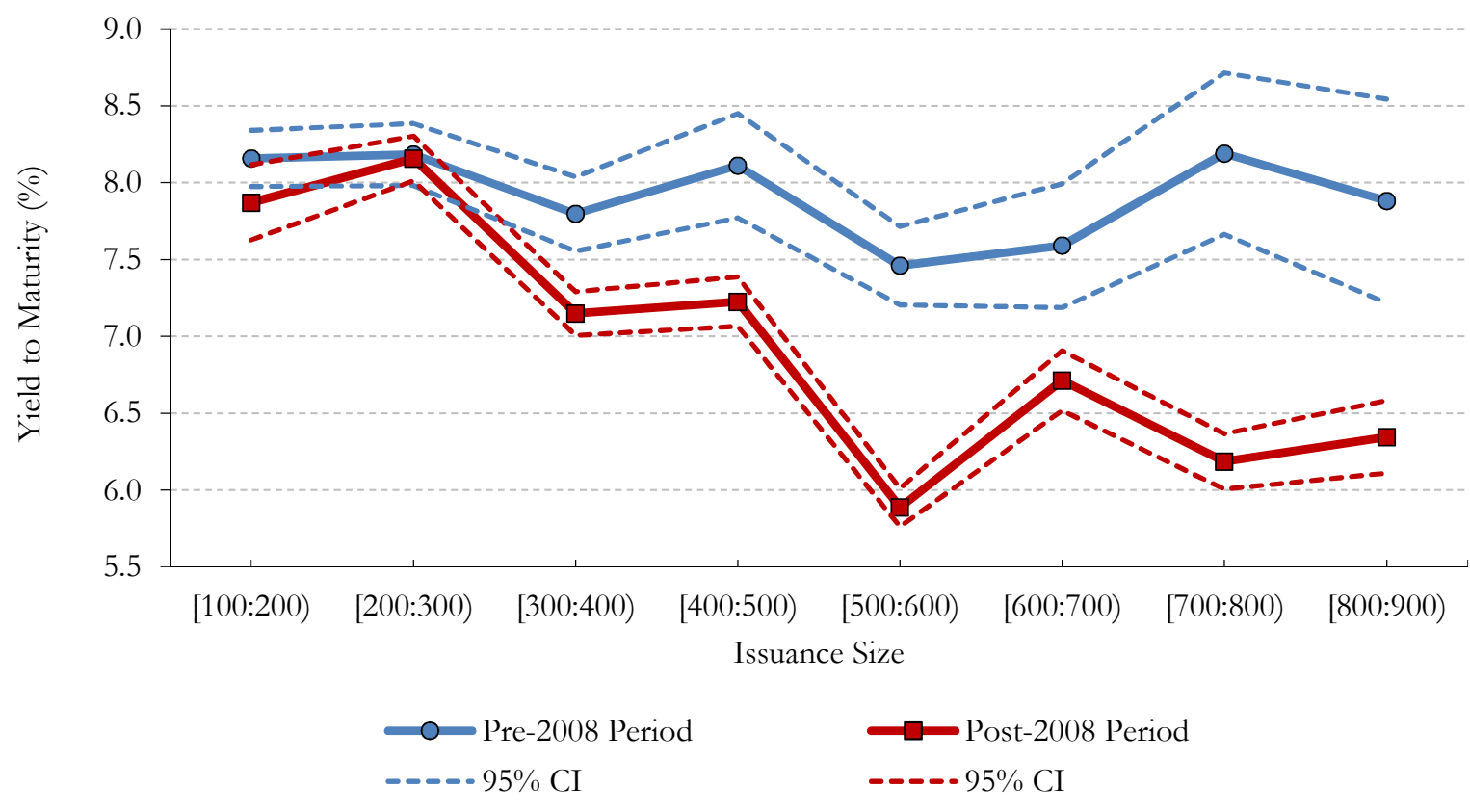

Panel B. Cumulative Distribution of Issuance Size, Pre and Post 2008

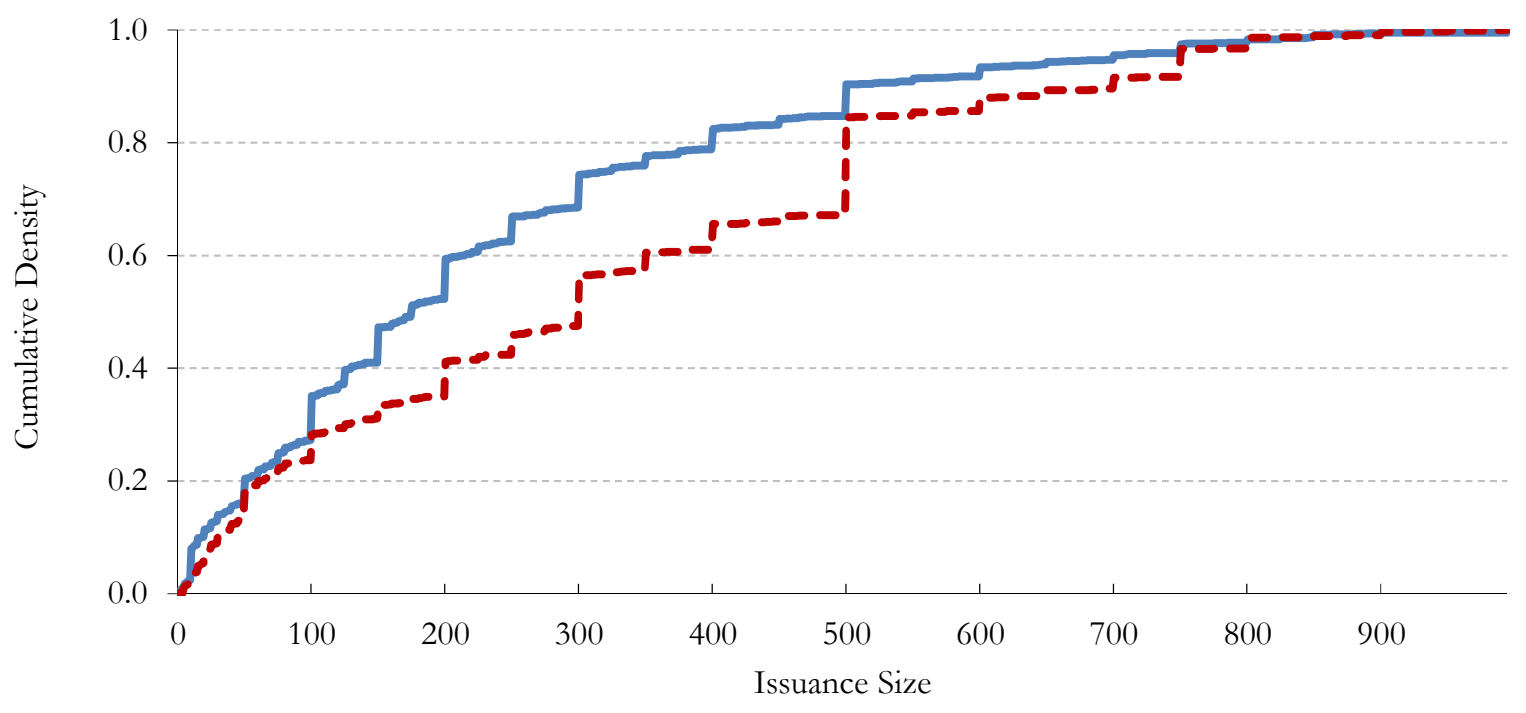

Pre-2008 Period _ _ - Post-2008 Period 


\section{Appendix Table 1 \\ List of Countries}

This table displays the list of markets classified as emerging and developed in the sample.

\begin{tabular}{|c|c|c|}
\hline Emerging Markets & Emerging Markets (Cont'd) & Developed Markets \\
\hline Argentina & Mongolia & Australia \\
\hline Azerbaijan & Morocco & Austria \\
\hline Bahrain & Nigeria & Belgium \\
\hline Brazil & Oman & Canada \\
\hline Chile & Panama & Denmark \\
\hline China & Peru & Finland \\
\hline Colombia & Philippines, The & France \\
\hline Croatia & Poland & Germany \\
\hline Czech Republic & Qatar & Greece \\
\hline Dominican Republic & Russian Federation & Hong Kong SAR, China \\
\hline Egypt, Arab Rep. & Saudi Arabia & Iceland \\
\hline El Salvador & Singapore & Ireland \\
\hline Guatemala & South Africa & Italy \\
\hline Hungary & Taiwan, China & Japan \\
\hline India & Thailand & Luxembourg \\
\hline Indonesia & Trinidad and Tobago & Netherlands \\
\hline Israel & Turkey & New Zealand \\
\hline Jamaica & Ukraine & Norway \\
\hline Kazakhstan & United Arab Emirates & Portugal \\
\hline Korea, Rep. & Venezuela, RB & Spain \\
\hline Kuwait & & Sweden \\
\hline Lebanon & & Switzerland \\
\hline Malaysia & & United Kingdom \\
\hline Mexico & & United States \\
\hline
\end{tabular}


Appendix Table 2

CEMBI and EMBI Requirements

This table reports the requirements for bonds to qualify for inclusion in the J.P. Morgan CEMBI and EMBI indexes.

\begin{tabular}{|c|c|c|c|}
\hline & \multicolumn{2}{|c|}{ CEMBI } & \multirow{2}{*}{ EMBIG Diversified } \\
\hline & CEMBI Broad/ Broad Div. & CEMBI / Div (Narrow) & \\
\hline Country/Region & \multicolumn{2}{|c|}{$\begin{array}{l}\text { Issuer needs to belong to a country in one of the following regions: } \\
\text { Asia ex Japan, Latam, Eastern Europe, Middle East/Africa. }\end{array}$} & $\begin{array}{l}\text { GNI per capita must be below the Index Income } \\
\text { Ceiling (IIC) for three consecutive years. }\end{array}$ \\
\hline Issuer & \multicolumn{2}{|c|}{$\begin{array}{l}\text { - Headquartered in an emerging market (EM) country, or } \\
\text { - } 100 \% \text { of the issuer's asset are within EM economies, or } \\
\text { - } 100 \% \text { secured by assets within EM economies. }\end{array}$} & $\mathrm{N} / \mathrm{A}$ \\
\hline Instrument Type & $\begin{array}{l}\text { All fixed, floaters, amortizers, and } \\
\text { capitalizers. } \\
\text { Defaulted bonds are excluded. }\end{array}$ & $\begin{array}{l}\text { All fixed, bullets (only two largest } \\
\text { instruments from any issuer). } \\
\text { Defaulted bonds are excluded. }\end{array}$ & $\begin{array}{l}\text { All fixed, floaters, amortizers, capitalizers, and } \\
\text { loans. }\end{array}$ \\
\hline Law/Settlement & \multicolumn{2}{|c|}{$\begin{array}{l}\text { Local law instruments are not eligible; Euroclearable or settled } \\
\text { through another institution outside issuing country. }\end{array}$} & $\mathrm{N} / \mathrm{A}$ \\
\hline $\begin{array}{l}\text { Includes Quasi- } \\
\text { Sovereign Bonds }\end{array}$ & \multicolumn{2}{|l|}{$\mathrm{N} / \mathrm{A}$} & Yes \\
\hline
\end{tabular}




\section{Appendix Table 3}

\section{Yield to Maturity and Probability of Issuing Bonds of Different Sizes, [400:500) and [500:550)}

This table reports mean tests for the yield to maturity and the probability of issuing an international U.S. dollar-denominated bond issued with face value between $\$ 400$ and \$500 million [400:500), and between \$500 and \$550 million [500:550), for firms in emerging markets and investment grade firms in developed markets during the pre-2008 (2000-2008) and post-2008 (2009-2016) periods. Panel A shows the yield to maturity (in percent) in each category. Panel B shows the percentage of issued bonds. Columns 1-3 show the mean tests and differences (pre and post 2008) for the [400:500) bonds separately for emerging and developed markets. Columns 4-6 show the mean tests and differences (pre and post 2008) for the [500:550) bonds. Column 7 shows the difference-in-difference effects between columns 3 and 6 for each region. Column 8 reports the triple difference between emerging and developed markets. The yield to maturity variable is winsorized at the $5 \%$ level. $*, * *$, and $* * *$ indicate statistical significance at the $10 \%, 5 \%$, and $1 \%$ levels, respectively.

\begin{tabular}{|c|c|c|c|c|c|c|c|c|}
\hline \multicolumn{9}{|c|}{ Panel A. Yield to Maturity } \\
\hline & \multicolumn{3}{|c|}{$[400: 500)$} & \multicolumn{3}{|c|}{$[500: 550)$} & \multirow{2}{*}{$\begin{array}{l}\text { Diff-in-Diff } \\
(7)=(6)-(3)\end{array}$} & \multirow{2}{*}{$\begin{array}{c}\text { Triple Diff } \\
(8)=\operatorname{EM}(7)-\operatorname{DM}(7)\end{array}$} \\
\hline & $\begin{array}{c}\text { Pre } 2008 \\
\quad(1) \\
\end{array}$ & $\begin{array}{c}\text { Post } 2008 \\
(2) \\
\end{array}$ & $\begin{array}{c}\text { Diff } \\
(3)=(2)-(1) \\
\end{array}$ & $\begin{array}{c}\text { Pre } 2008 \\
(4) \\
\end{array}$ & $\begin{array}{c}\text { Post } 2008 \\
(5) \\
\end{array}$ & $\begin{array}{c}\text { Diff } \\
(6)=(5)-(4) \\
\end{array}$ & & \\
\hline Emerging Markets & $\begin{array}{r}7.189 \\
(0.232)\end{array}$ & $\begin{array}{r}6.223 \\
(0.189)\end{array}$ & $\begin{array}{l}-0.966 \text { *** } \\
(0.312)\end{array}$ & $\begin{array}{r}7.089 \\
(0.188)\end{array}$ & $\begin{array}{r}4.883 \\
(0.079)\end{array}$ & $\begin{array}{l}-2.206 \text { *** } \\
(0.195)\end{array}$ & $\begin{array}{l}-1.240 \text { *** } \\
(0.338)\end{array}$ & $-1.029 * * *$ \\
\hline Developed Markets & $\begin{array}{r}5.534 \\
(0.077) \\
\end{array}$ & $\begin{array}{r}4.076 \\
(0.075) \\
\end{array}$ & $\begin{array}{l}-1.458 \text { *** } \\
(0.109)\end{array}$ & $\begin{array}{r}5.270 \\
(0.073) \\
\end{array}$ & $\begin{array}{r}3.602 \\
(0.061) \\
\end{array}$ & $\begin{array}{l}-1.669 * * * \\
(0.098)\end{array}$ & $\begin{array}{r}-0.211 \\
(0.150) \\
\end{array}$ & $(0.344)$ \\
\hline \multicolumn{9}{|c|}{ Panel B. Issuance } \\
\hline & \multicolumn{3}{|c|}{$[400: 500)$} & \multicolumn{3}{|c|}{$[500: 550)$} & Diff-in-Diff & Triple Diff \\
\hline & $\begin{array}{c}\text { Pre } 2008 \\
(1) \\
\end{array}$ & $\begin{array}{c}\text { Post } 2008 \\
(2) \\
\end{array}$ & $\begin{array}{c}\text { Diff } \\
(3)=(2)-(1) \\
\end{array}$ & $\begin{array}{c}\text { Pre } 2008 \\
(4) \\
\end{array}$ & $\begin{array}{l}\text { Post } 2008 \\
\qquad 5) \\
\end{array}$ & $\begin{array}{c}\text { Diff } \\
(6)=(5)-(4) \\
\end{array}$ & $(7)=(6)-(3)$ & $(8)=\operatorname{EM}(7)-\operatorname{DM}(7)$ \\
\hline Emerging Markets & $\begin{array}{r}0.043 \\
(0.004)\end{array}$ & $\begin{array}{r}0.063 \\
(0.005)\end{array}$ & $\begin{array}{l}0.020 \text { *** } \\
(0.006)\end{array}$ & $\begin{array}{r}0.060 \\
(0.005)\end{array}$ & $\begin{array}{r}0.179 \\
(0.007)\end{array}$ & $\begin{array}{l}0.120 \text { *** } \\
(0.009)\end{array}$ & $\begin{array}{l}0.099 \text { *** } \\
(0.011)\end{array}$ & $0.071 * * *$ \\
\hline Developed Markets & $\begin{array}{r}0.043 \\
(0.002)\end{array}$ & $\begin{array}{r}0.047 \\
(0.003)\end{array}$ & $\begin{array}{r}0.004 \\
(0.003)\end{array}$ & $\begin{array}{r}0.067 \\
(0.003)\end{array}$ & $\begin{array}{r}0.100 \\
(0.004)\end{array}$ & $\begin{array}{l}0.033^{* * *} \\
(0.005)\end{array}$ & $\begin{array}{l}0.028 \text { *** } \\
(0.006)\end{array}$ & $(0.013)$ \\
\hline
\end{tabular}




\section{Appendix Table 4 \\ Probability of Issuing Bonds of Different Sizes \\ Adding Firm Fixed Effects}

This table reports difference-in-difference regressions of the change in the probability of issuing an international U.S. dollardenominated bond of a certain size in millions of U.S. dollars, pre and post 2008, for firms in emerging markets (EM) relative to investment grade firms in developed markets. The analysis is restricted to positive bond issuance observations during 2000-2016. The table reports the regressions for the bond issuance dummy of each size bucket on the interaction of the post 2008 dummy (equal to 1 for 2009-2016) with the emerging market dummy. All regressions include bond-firm controls, namely, a dummy indicating whether the bond was issued publicly or privately, a dummy indicating whether the firm is foreign-owned, a dummy indicating whether the firm has partial government ownership, and a fixed or flexible coupon dummy. They also include firm, maturity, and quarterly-year fixed effects (FE). Standard errors are clustered at the country and quarter-year levels. *, **, and *** indicate statistical significance at the $10 \%, 5 \%$, and $1 \%$ levels, respectively.

\begin{tabular}{lccccccccc}
\hline \multicolumn{10}{c}{ Dependent Variable: Dummy=1 if Issuance=[X:X+100) } \\
\hline & \multicolumn{10}{c}{ Probability of Issuing Debt of a Certain Amount } \\
\cline { 2 - 11 } & $(1)$ & $(2)$ & $(3)$ & $(4)$ & $(5)$ & $(6)$ & $(7)$ & $(8)$ & $(9)$ \\
& $-0: 100)$ & {$[100: 200)$} & {$[200: 300)$} & {$[300: 400)$} & {$[400: 500)$} & {$[500: 600)$} & {$[600: 700)$} & {$[700: 800)$} & {$[800: 900)$} \\
\hline EM*Post 2008 & -0.001 & $-0.071 *$ & $-0.041 * *$ & 0.012 & $-0.031 *$ & $0.092 * * *$ & 0.010 & 0.029 & -0.005 \\
& $(0.036)$ & $(0.038)$ & $(0.019)$ & $(0.025)$ & $(0.017)$ & $(0.026)$ & $(0.016)$ & $(0.018)$ & $(0.007)$ \\
Bond Controls & & & & & & & & & \\
Frim FE & Yes & Yes & Yes & Yes & Yes & Yes & Yes & Yes & Yes \\
Maturity FE & Yes & Yes & Yes & Yes & Yes & Yes & Yes & Yes & Yes \\
Quarter-Year FE & Yes & Yes & Yes & Yes & Yes & Yes & Yes & Yes & Yes \\
\hline Mean Probability & Yes & Yes & Yes & Yes & Yes & Yes & Yes & Yes & Yes \\
Number of Countries & 0.367 & 0.171 & 0.125 & 0.0875 & 0.0466 & 0.101 & 0.0293 & 0.0503 & 0.0155 \\
Number of Observations & 68 & 68 & 68 & 68 & 68 & 68 & 68 & 68 & 68 \\
$\mathrm{R}^{2}$ & 17,022 & 17,022 & 17,022 & 17,022 & 17,022 & 17,022 & 17,022 & 17,022 & 17,022 \\
\hline
\end{tabular}




\section{Appendix Table 5}

\section{Yield to Maturity and Issuance Sizes: Developed Market Coefficients}

This table reports difference-in-difference regressions of the yield to maturity of international U.S. dollardenominated bonds of different sizes in millions of U.S. dollars, measuring the relative change before and after 2008 for investment grade firms in developed markets (DM) compared to firms in emerging markets. The analysis is restricted to positive bond issuance observations during 2000-2016 and includes both emerging market and investment grade developed market issuers. The full equation estimated is Equation (7) in the text. Columns 1-4 report the coefficients $\beta_{X}^{D M}$ of the dummy of each bucket size and the coefficients $\beta_{X}^{D M, P o s t}$ of the interaction term between the dummy of each bucket size and the post 2008 dummy (equal to 1 for 2009-2016). The coefficients $\beta_{X}^{E M}$ and $\beta_{X}^{E M, P o s t}$ are estimated but are not reported in this table to conserve space. They are reported instead in Table 3 and Appendix Table 6. Column 2 includes country, industry-year, and quarter-year fixed effects (FE). Column 3 includes country, industry-year, maturity, rating, quarter-year fixed effects, in addition to bond-firm controls. Bond-firm controls include a dummy indicating whether the bond was issued publicly or privately, a dummy indicating whether the firm is foreign-owned, a dummy indicating whether the firm has partial government ownership, and a fixed or flexible coupon dummy. Column 4 reports a placebo test using only nonindex-eligible bonds, which are those with less than five years of maturity or flexible coupon rates. Standard errors are clustered at the country and quarter-year levels. The yield to maturity variable is winsorized at the $5 \%$ level. *, $* *$, and $* * *$ indicate statistical significance at the $10 \%, 5 \%$, and $1 \%$ levels, respectively.

\begin{tabular}{|c|c|c|c|c|c|}
\hline & \multirow{2}{*}{$\begin{array}{c}\text { Associated } \\
\text { Coefficients }\end{array}$} & \multicolumn{4}{|c|}{ Dependent Variable: Yield to Maturity } \\
\hline & & (1) & $(2)$ & (3) & (4) \\
\hline$[100: 200)$ & $\beta_{100}^{D M}$ & $\begin{array}{l}-1.155 \text { *** } \\
(0.279)\end{array}$ & $\begin{array}{l}-0.713 \text { *** } \\
(0.193)\end{array}$ & $\begin{array}{l}-0.294 \text { ** } \\
(0.135)\end{array}$ & $\begin{array}{l}-2.202 \text { *** } \\
(0.518)\end{array}$ \\
\hline$[200: 300)$ & $\beta_{200}^{D M}$ & $\begin{array}{l}-0.825 \text { *** } \\
(0.200)\end{array}$ & $\begin{array}{l}-0.549 \text { *** } \\
(0.166)\end{array}$ & $\begin{array}{l}-0.352 \text { *** } \\
(0.123)\end{array}$ & $\begin{array}{l}-1.946 \text { *** } \\
(0.501)\end{array}$ \\
\hline$[300: 400)$ & $\beta_{300}^{D M}$ & $\begin{array}{l}-0.519 \text { ** } \\
(0.201)\end{array}$ & $\begin{array}{l}-0.377 \text { ** } \\
(0.180)\end{array}$ & $\begin{array}{l}-0.244 \\
(0.147)\end{array}$ & $\begin{array}{l}-1.495 \text { *** } \\
(0.553)\end{array}$ \\
\hline$[400: 500)$ & $\beta_{400}^{D M}$ & $\begin{array}{l}-0.468 \text { ** } \\
(0.221)\end{array}$ & $\begin{array}{l}-0.343 * \\
(0.191)\end{array}$ & $\begin{array}{l}-0.292 \\
(0.182)\end{array}$ & $\begin{array}{l}-1.585 \text { *** } \\
(0.535)\end{array}$ \\
\hline$[500: 600)$ & $\beta_{500}^{D M}$ & $\begin{array}{l}-0.645 \text { *** } \\
(0.158)\end{array}$ & $\begin{array}{l}-0.344 \text { ** } \\
(0.158)\end{array}$ & $\begin{array}{l}-0.195 * \\
(0.111)\end{array}$ & $\begin{array}{l}-2.056 \text { *** } \\
(0.567)\end{array}$ \\
\hline$[600: 700)$ & $\beta_{600}^{D M}$ & $\begin{array}{l}-0.271 \\
(0.170)\end{array}$ & $\begin{array}{l}-0.199 \\
(0.180)\end{array}$ & $\begin{array}{l}-0.219 \\
(0.201)\end{array}$ & $\begin{array}{l}-1.369 \text { *** } \\
(0.437)\end{array}$ \\
\hline$[700: 800)$ & $\beta_{700}^{D M}$ & $\begin{array}{l}-0.155 \\
(0.184)\end{array}$ & $\begin{array}{r}0.008 \\
(0.178)\end{array}$ & $\begin{array}{l}-0.081 \\
(0.144)\end{array}$ & $\begin{array}{l}-0.285 \\
(0.509)\end{array}$ \\
\hline$[800: 900)$ & $\beta_{800}^{D M}$ & $\begin{array}{r}0.000 \\
(0.000)\end{array}$ & $\begin{array}{r}0.000 \\
(0.000)\end{array}$ & $\begin{array}{r}0.000 \\
(0.000)\end{array}$ & $\begin{array}{r}0.000 \\
(0.000)\end{array}$ \\
\hline [100:200)*Post 2008 & $\beta_{100}^{D M, \text { Post }}$ & $\begin{array}{l}-0.977 \text { ** } \\
(0.412)\end{array}$ & $\begin{array}{l}-4.703 \text { *** } \\
(0.259)\end{array}$ & $\begin{array}{l}-5.968 \text { *** } \\
(0.353)\end{array}$ & $\begin{array}{l}-2.222 \text { *** } \\
(0.505)\end{array}$ \\
\hline [200:300)*Post 2008 & $\beta_{200}^{D M, P o s t}$ & $\begin{array}{l}-0.845 \text { *** } \\
(0.205)\end{array}$ & $\begin{array}{l}-4.679 \text { *** } \\
(0.276)\end{array}$ & $\begin{array}{l}-6.028 * * * \\
(0.341)\end{array}$ & $\begin{array}{l}-1.5866^{* * *} \\
(0.541)\end{array}$ \\
\hline [300:400)*Post 2008 & $\beta_{300}^{D M, P o s t}$ & $\begin{array}{l}-1.319 \text { *** } \\
(0.127)\end{array}$ & $\begin{array}{l}-4.847 \text { *** } \\
(0.276)\end{array}$ & $\begin{array}{l}-6.178 \text { *** } \\
(0.336)\end{array}$ & $\begin{array}{l}-2.327 \text { *** } \\
(0.407)\end{array}$ \\
\hline [400:500)*Post 2008 & $\beta_{400}^{D M, \text { Post }}$ & $\begin{array}{l}-1.458 \text { *** } \\
(0.154)\end{array}$ & $\begin{array}{l}-5.147 \text { *** } \\
(0.224)\end{array}$ & $\begin{array}{l}-6.224 \text { *** } \\
(0.288)\end{array}$ & $\begin{array}{l}-2.4444^{* * *} \\
(0.388)\end{array}$ \\
\hline [500:600)*Post 2008 & $\beta_{500}^{D M, P o s t}$ & $\begin{array}{l}-1.681 \text { *** } \\
(0.154)\end{array}$ & $\begin{array}{l}-5.181 \text { *** } \\
(0.235)\end{array}$ & $\begin{array}{l}-6.396 * * * \\
(0.305)\end{array}$ & $\begin{array}{l}-2.195 \text { *** } \\
(0.245)\end{array}$ \\
\hline [600:700)*Post 2008 & $\beta_{600}^{D M, P o s t}$ & $\begin{array}{l}-1.907 \text { *** } \\
(0.251)\end{array}$ & $\begin{array}{l}-5.287 \text { *** } \\
(0.240)\end{array}$ & $\begin{array}{l}-6.308 \text { *** } \\
(0.341)\end{array}$ & $\begin{array}{l}-2.965 \text { *** } \\
(0.526)\end{array}$ \\
\hline$[700: 800) *$ Post 2008 & $\beta_{700}^{D M, \text { Post }}$ & $\begin{array}{l}-2.344 \text { *** } \\
(0.148)\end{array}$ & $\begin{array}{l}-5.701 \text { *** } \\
(0.292)\end{array}$ & $\begin{array}{l}-6.623 * * * \\
(0.312)\end{array}$ & $\begin{array}{l}-4.113 \text { *** } \\
(0.384)\end{array}$ \\
\hline [800:900)*Post 2008 & $\beta_{800}^{D M, P o s t}$ & $\begin{array}{l}-2.048 \text { *** } \\
(0.214)\end{array}$ & $\begin{array}{l}-5.3 \text { *** } \\
(0.271)\end{array}$ & $\begin{array}{l}-6.505 \text { *** } \\
(0.331)\end{array}$ & $\begin{array}{l}-4.239 \text { *** } \\
(0.512)\end{array}$ \\
\hline Bond Controls & & No & No & Yes & No \\
\hline Country FE & & No & Yes & Yes & No \\
\hline Industry-Year FE & & No & Yes & Yes & No \\
\hline Maturity FE & & No & No & Yes & No \\
\hline Ratings FE & & No & No & Yes & No \\
\hline Quarter-Year FE & & No & Yes & Yes & No \\
\hline Number of Observations & & 7,939 & 7,939 & 7,818 & 1,600 \\
\hline $\mathrm{R}^{2}$ & & 0.344 & 0.659 & 0.763 & 0.471 \\
\hline
\end{tabular}




\section{Appendix Table 6 \\ Yield to Maturity and Issuance Sizes: Emerging Market Coefficients, Pre 2008}

This table reports difference-in-difference regressions of the yield to maturity of international U.S. dollardenominated bonds of different sizes in millions of U.S. dollars, measuring the relative change before 2008 for firms in emerging markets (EM) compared to investment grade firms in developed markets. The analysis is restricted to positive bond issuance observations during 2000-2016 and includes both emerging market and investment grade developed market issuers. The full equation estimated is Equation (7) in the text. Columns 1-4 report the coefficients $\beta_{X}^{E M}$ of the interaction term between the dummy of each bucket size and the emerging market dummy. The coefficients $\beta_{X}^{D M}, \beta_{X}^{D M, P o s t}$ and $\beta_{X}^{E M, P o s t}$ are estimated but are not reported in this table to conserve space. They are reported instead in Table 3 and Appendix Table 5. Column 2 includes country, industry-year, and quarter-year fixed effects (FE). Column 3 includes country, industry-year, maturity, rating, quarter-year fixed effects, in addition to bond-firm controls. Bond-firm controls include a dummy indicating whether the bond was issued publicly or privately, a dummy indicating whether the firm is foreign-owned, a dummy indicating whether the firm has partial government ownership, and a fixed or flexible coupon dummy. Column 4 reports a placebo test using only non-index-eligible bonds, which are those with less than five years of maturity or flexible coupon rates. Standard errors are clustered at the country and quarter-year levels. The yield to maturity variable is winsorized at the $5 \%$ level. *, **, and *** indicate statistical significance at the $10 \%$, $5 \%$, and $1 \%$ levels, respectively.

\begin{tabular}{|c|c|c|c|c|c|}
\hline & \multirow{2}{*}{$\begin{array}{l}\text { Associated } \\
\text { Coefficients }\end{array}$} & \multicolumn{4}{|c|}{ Dependent Variable: Yield to Maturity } \\
\hline & & (1) & (2) & (3) & (4) \\
\hline $\mathrm{EM}^{*}[100: 200)$ & $\beta_{100}^{E M}$ & $\begin{array}{l}2.998 \text { *** } \\
(0.393)\end{array}$ & $\begin{array}{l}2.942 \text { *** } \\
(0.499)\end{array}$ & $\begin{array}{l}2.165 \text { *** } \\
(0.454)\end{array}$ & $\begin{array}{l}3.664 \text { *** } \\
(0.572)\end{array}$ \\
\hline $\mathrm{EM}^{*}[200: 300)$ & $\beta_{200}^{E M}$ & $\begin{array}{l}2.592 \text { *** } \\
(0.369)\end{array}$ & $\begin{array}{l}2.75^{* * *} \\
(0.431)\end{array}$ & $\begin{array}{l}2.014 \text { *** } \\
(0.425)\end{array}$ & $\begin{array}{l}3.404 \text { *** } \\
(0.697)\end{array}$ \\
\hline $\mathrm{EM}^{*}[300: 400)$ & $\beta_{300}^{E M}$ & $\begin{array}{l}1.687 \text { *** } \\
(0.450)\end{array}$ & $\begin{array}{l}2.479 \text { *** } \\
(0.489)\end{array}$ & $\begin{array}{l}1.678 \text { *** } \\
(0.419)\end{array}$ & $\begin{array}{l}2.63 \text { *** } \\
(0.914)\end{array}$ \\
\hline $\mathrm{EM}^{*}[400: 500)$ & $\beta_{400}^{E M}$ & $\begin{array}{l}1.655^{* * *} \\
(0.448)\end{array}$ & $\begin{array}{l}1.872 \text { *** } \\
(0.430)\end{array}$ & $\begin{array}{l}1.278^{* * *} \\
(0.387)\end{array}$ & $\begin{array}{l}3.193 \text { *** } \\
(0.457)\end{array}$ \\
\hline $\mathrm{EM}^{*}[500: 600)$ & $\beta_{500}^{E M}$ & $\begin{array}{l}1.742 \text { *** } \\
(0.299)\end{array}$ & $\begin{array}{l}1.946 \text { *** } \\
(0.545)\end{array}$ & $\begin{array}{l}1.321 \text { *** } \\
(0.446)\end{array}$ & $\begin{array}{l}2.51 \text { *** } \\
(0.746)\end{array}$ \\
\hline $\mathrm{EM}^{*}[600: 700)$ & $\beta_{600}^{E M}$ & $\begin{array}{r}0.478 \\
(0.490)\end{array}$ & $\begin{array}{c}1.18 \text { ** } \\
(0.586)\end{array}$ & $\begin{array}{c}0.932 * \\
(0.509)\end{array}$ & $\begin{array}{l}1.545 \text { *** } \\
(0.440)\end{array}$ \\
\hline $\mathrm{EM}^{*}[700: 800)$ & $\beta_{700}^{E M}$ & $\begin{array}{r}0.544 \\
(0.392)\end{array}$ & $\begin{array}{l}1.776 \text { ** } \\
(0.757)\end{array}$ & $\begin{array}{c}1.112 * \\
(0.582)\end{array}$ & $\begin{array}{l}-0.639 \\
(0.407)\end{array}$ \\
\hline $\mathrm{EM}^{*}[800: 900)$ & $\beta_{800}^{E M}$ & $\begin{array}{r}0.406 \\
(0.557)\end{array}$ & $\begin{array}{r}1.086 \\
(0.970)\end{array}$ & $\begin{array}{r}0.489 \\
(0.604)\end{array}$ & $\begin{array}{l}-0.424 \\
(0.494)\end{array}$ \\
\hline Bond Controls & & No & No & Yes & No \\
\hline Country FE & & No & Yes & Yes & No \\
\hline Industry-Year FE & & No & Yes & Yes & No \\
\hline Maturity FE & & No & No & Yes & No \\
\hline Ratings FE & & No & No & Yes & No \\
\hline Quarter-Year FE & & No & Yes & Yes & No \\
\hline $\begin{array}{l}\text { Diff-in-Diff } \\
\end{array}$ & $\beta_{500}^{E M}-\beta_{400}^{E M}$ & 0.087 & 0.074 & 0.043 & -0.683 \\
\hline P-Value & & 0.722 & 0.838 & 0.875 & 0.456 \\
\hline Number of Observations & & 7,939 & 7,939 & 7,818 & 1,600 \\
\hline $\mathrm{R}^{2}$ & & 0.344 & 0.659 & 0.763 & 0.471 \\
\hline
\end{tabular}




\section{Appendix Table 7 \\ Probability of Issuing Bonds of Different Sizes Adding Maturity-Time and Ratings-Time Fixed Effects}

This table reports difference-in-difference regressions of the change in the probability of issuing an international U.S. dollar-denominated bond of a certain size in millions of U.S. dollars, pre and post 2008, for firms in emerging markets (EM) relative to investment grade firms in developed markets. The analysis is restricted to positive bond issuance observations during 2000-2016. The table reports regressions for the bond issuance dummy of each size bucket on the interaction of the post 2008 dummy (equal to one for 2009-2016) with the emerging market dummy. The regressions in Panel A include firm, industry-year, and maturity-quarter-year fixed effects (FE). The regressions in Panel B include firm, industry-year, and ratings-quarter-year fixed effects. All the regressions include bond-firm controls, namely, a dummy indicating whether the bond was issued publicly or privately, a dummy indicating whether the firm is foreign-owned, a dummy indicating whether the firm has partial government ownership, and a fixed or flexible coupon dummy. Standard errors are clustered at the country and quarter-year levels. *, **, and *** indicate statistical significance at the $10 \%, 5 \%$, and $1 \%$ levels, respectively.

\begin{tabular}{|c|c|c|c|c|c|c|c|c|c|}
\hline \multicolumn{10}{|c|}{ Panel A. Dependent Variable: Dummy $=1$ if Issuance $=[X: X+100)$} \\
\hline & \multicolumn{9}{|c|}{ Probability of Issuing Debt of a Certain Amount } \\
\hline & $\begin{array}{c}(1) \\
(0: 100)\end{array}$ & $\begin{array}{c}(2) \\
{[100: 200)}\end{array}$ & $\begin{array}{c}(3) \\
{[200: 300)}\end{array}$ & $\begin{array}{c}(4) \\
{[300: 400)}\end{array}$ & $\begin{array}{c}5) \\
{[400: 500)}\end{array}$ & $\begin{array}{c}(6) \\
{[500: 600)}\end{array}$ & $\begin{array}{c}(7) \\
{[600: 700)}\end{array}$ & $\begin{array}{c}(8) \\
{[700: 800)}\end{array}$ & $\begin{array}{c}(9) \\
{[800: 900)}\end{array}$ \\
\hline EM*Post 2008 & $\begin{array}{r}0.012 \\
(0.042)\end{array}$ & $\begin{array}{l}-0.090 * \\
(0.048)\end{array}$ & $\begin{array}{l}-0.035 \\
(0.024)\end{array}$ & $\begin{array}{r}0.019 \\
(0.025)\end{array}$ & $\begin{array}{l}-0.020 \\
(0.015)\end{array}$ & $\begin{array}{l}0.083 \text { *** } \\
(0.023)\end{array}$ & $\begin{array}{r}0.018 \\
(0.013)\end{array}$ & $\begin{array}{r}0.012 \\
(0.017)\end{array}$ & $\begin{array}{l}-0.001 \\
(0.009)\end{array}$ \\
\hline Bond Controls & Yes & Yes & Yes & Yes & Yes & Yes & Yes & Yes & Yes \\
\hline Firm FE & Yes & Yes & Yes & Yes & Yes & Yes & Yes & Yes & Yes \\
\hline Industry-Year FE & Yes & Yes & Yes & Yes & Yes & Yes & Yes & Yes & Yes \\
\hline Maturity-Quarter-Year FE & Yes & Yes & Yes & Yes & Yes & Yes & Yes & Yes & Yes \\
\hline Mean Probability & 0.367 & 0.170 & 0.125 & 0.0876 & 0.0469 & 0.101 & 0.0296 & 0.0506 & 0.0157 \\
\hline Number of Countries & 68 & 68 & 68 & 68 & 68 & 68 & 68 & 68 & 68 \\
\hline Number of Observations & 17,147 & 17,147 & 17,147 & 17,147 & 17,147 & 17,147 & 17,147 & 17,147 & 17,147 \\
\hline $\mathrm{R}^{2}$ & 0.578 & 0.380 & 0.394 & 0.435 & 0.452 & 0.417 & 0.437 & 0.386 & 0.459 \\
\hline \multicolumn{10}{|c|}{ Panel B. Dependent Variable: Dummy $=1$ if Issuance $=[X: X+100)$} \\
\hline & \multicolumn{9}{|c|}{ Probability of Issuing Debt of a Certain Amount } \\
\hline & $\begin{array}{c}(1) \\
(0: 100) \\
\end{array}$ & $\begin{array}{c}(2) \\
{[100: 200)} \\
\end{array}$ & $\begin{array}{c}3) \\
{[200: 300)} \\
\end{array}$ & $\begin{array}{c}(4) \\
{[300: 400)} \\
\end{array}$ & $\begin{array}{c}(5) \\
{[400: 500)} \\
\end{array}$ & $\begin{array}{c}(6) \\
{[500: 600)} \\
\end{array}$ & $\begin{array}{c}(7) \\
{[600: 700)} \\
\end{array}$ & $\begin{array}{c}(8) \\
{[700: 800)} \\
\end{array}$ & $\begin{array}{c}(9) \\
{[800: 900)} \\
\end{array}$ \\
\hline EM*Post 2008 & $\begin{array}{r}0.014 \\
(0.047)\end{array}$ & $\begin{array}{l}-0.087 * \\
(0.046)\end{array}$ & $\begin{array}{l}-0.027 \\
(0.032)\end{array}$ & $\begin{array}{r}0.017 \\
(0.028)\end{array}$ & $\begin{array}{l}-0.001 \\
(0.019)\end{array}$ & $\begin{array}{r}0.029 \\
(0.027)\end{array}$ & $\begin{array}{l}0.039 \text { ** } \\
(0.016)\end{array}$ & $\begin{array}{r}0.003 \\
(0.015)\end{array}$ & $\begin{array}{r}0.005 \\
(0.009)\end{array}$ \\
\hline Bond Controls & Yes & Yes & Yes & Yes & Yes & Yes & Yes & Yes & Yes \\
\hline Firm FE & Yes & Yes & Yes & Yes & Yes & Yes & Yes & Yes & Yes \\
\hline Industry-Year FE & Yes & Yes & Yes & Yes & Yes & Yes & Yes & Yes & Yes \\
\hline Ratings-Quarter-Year FE & Yes & Yes & Yes & Yes & Yes & Yes & Yes & Yes & Yes \\
\hline Mean Probability & 0.369 & 0.170 & 0.124 & 0.0869 & 0.0469 & 0.101 & 0.0295 & 0.0507 & 0.0158 \\
\hline Number of Countries & 67 & 67 & 67 & 67 & 67 & 67 & 67 & 67 & 67 \\
\hline Number of Observations & 16,996 & 16,996 & 16,996 & 16,996 & 16,996 & 16,996 & 16,996 & 16,996 & 16,996 \\
\hline $\mathrm{R}^{2}$ & 0.598 & 0.406 & 0.437 & 0.490 & 0.499 & 0.460 & 0.481 & 0.440 & 0.504 \\
\hline
\end{tabular}




\section{Appendix Table 8 \\ Probability of Issuing Bonds of Different Sizes \\ Demand for Safe U.S. Dollar Assets}

This table reports difference-in-difference regressions of the change in the probability of issuing an international U.S. dollardenominated bond of a certain size in millions of U.S. dollars, pre and post 2008, for firms in emerging markets (EM) relative to investment grade firms in developed markets. The analysis is restricted to positive bond issuance observations during 2000-2016. Panel A reports the regressions for the bond issuance dummy of each size bucket on the interaction of the post 2008 dummy and the emerging market dummy and on the interaction of the U.S. Treasury basis and the emerging market dummy. Panel B reports the same type of regressions, but including the additional interaction of the post 2008 dummy, the emerging market dummy, and the U.S. treasury basis. The U.S. treasury basis is the difference between the yield on a cash position in U.S. Treasurys and the synthetic dollar yield constructed from a cash position in a foreign bond, that is hedged back into dollars. It is computed as in Jian et al. (2018). All regressions include bond-firm controls, namely, a dummy indicating whether the bond was issued publicly or privately, a dummy indicating whether the firm is foreign-owned, a dummy indicating whether the firm has partial government ownership, and a fixed or flexible coupon dummy. They also include firm, industry-year, and quarter-year fixed effects (FE). Standard errors are clustered at the country and quarter-year levels. The yield to maturity variable is winsorized at the $5 \%$ level. *, **, and *** indicate statistical significance at the $10 \%, 5 \%$, and $1 \%$ levels, respectively.

\begin{tabular}{|c|c|c|c|c|c|c|c|c|c|}
\hline \multicolumn{10}{|c|}{ Panel A. Dependent Variable: Dummy $=1$ if Issuance $=[X: X+100)$} \\
\hline & \multicolumn{9}{|c|}{ Probability of Issuing Debt of a Certain Amount } \\
\hline & $\begin{array}{c}(1) \\
(0: 100) \\
\end{array}$ & $\begin{array}{c}(2) \\
{[100: 200)} \\
\end{array}$ & $\begin{array}{c}(3) \\
{[200: 300)} \\
\end{array}$ & $\begin{array}{c}(4) \\
{[300: 400)} \\
\end{array}$ & $\begin{array}{c}(5) \\
{[400: 500)} \\
\end{array}$ & $\begin{array}{c}(6) \\
{[500: 600)} \\
\end{array}$ & $\begin{array}{c}(7) \\
{[600: 700)} \\
\end{array}$ & $\begin{array}{c}(8) \\
{[700: 800)} \\
\end{array}$ & $\begin{array}{c}(9) \\
{[800: 900)} \\
\end{array}$ \\
\hline EM*Post 2008 & $\begin{array}{r}0.020 \\
(0.039)\end{array}$ & $\begin{array}{l}-0.071 \\
(0.053)\end{array}$ & $\begin{array}{l}-0.034 \\
(0.022)\end{array}$ & $\begin{array}{r}0.012 \\
(0.025)\end{array}$ & $\begin{array}{l}-0.021 \\
(0.015)\end{array}$ & $\begin{array}{l}0.073 \text { *** } \\
(0.022)\end{array}$ & $\begin{array}{r}0.017 \\
(0.013)\end{array}$ & $\begin{array}{r}0.005 \\
(0.017)\end{array}$ & $\begin{array}{r}-0.003 \\
(0.010)\end{array}$ \\
\hline EM*U.S. Treasury Basis & $\begin{array}{l}-0.195^{* * *} \\
(0.061)\end{array}$ & $\begin{array}{r}-0.061 \\
(0.055)\end{array}$ & $\begin{array}{l}0.086 \text { ** } \\
(0.042)\end{array}$ & $\begin{array}{l}0.099 \text { ** } \\
(0.039)\end{array}$ & $\begin{array}{r}0.002 \\
(0.033)\end{array}$ & $\begin{array}{r}0.062 \\
(0.042)\end{array}$ & $\begin{array}{l}-0.011 \\
(0.022)\end{array}$ & $\begin{array}{r}0.025 \\
(0.016)\end{array}$ & $\begin{array}{r}0.000 \\
(0.016)\end{array}$ \\
\hline Bond Controls & Yes & Yes & Yes & Yes & Yes & Yes & Yes & Yes & Yes \\
\hline Firm FE & Yes & Yes & Yes & Yes & Yes & Yes & Yes & Yes & Yes \\
\hline Industry-Year FE & Yes & Yes & Yes & Yes & Yes & Yes & Yes & Yes & Yes \\
\hline Quarter-Year FE & Yes & Yes & Yes & Yes & Yes & Yes & Yes & Yes & Yes \\
\hline Mean Probability & 0.367 & 0.170 & 0.125 & 0.0876 & 0.0469 & 0.101 & 0.0296 & 0.0506 & 0.0157 \\
\hline Number of Countries & 68 & 68 & 68 & 68 & 68 & 68 & 68 & 68 & 68 \\
\hline Number of Observations & 17,147 & 17,147 & 17,147 & 17,147 & 17,147 & 17,147 & 17,147 & 17,147 & 17,147 \\
\hline $\mathrm{R}^{2}$ & 0.572 & 0.369 & 0.390 & 0.432 & 0.449 & 0.410 & 0.434 & 0.380 & 0.457 \\
\hline \multicolumn{10}{|c|}{ Panel B. Dependent Variable: Dummy $=1$ if Issuance $=[X: X+100)$} \\
\hline & \multicolumn{9}{|c|}{ Probability of Issuing Debt of a Certain Amount } \\
\hline & $\begin{array}{c}(1) \\
(0: 100)\end{array}$ & $\begin{array}{c}(2) \\
{[100: 200)}\end{array}$ & $\begin{array}{c}(3) \\
{[200: 300)}\end{array}$ & $\begin{array}{c}(4) \\
{[300: 400)}\end{array}$ & $\begin{array}{c}(5) \\
{[400: 500)}\end{array}$ & $\begin{array}{c}(6) \\
{[500: 600)}\end{array}$ & $\begin{array}{c}(7) \\
{[600: 700)}\end{array}$ & $\begin{array}{c}(8) \\
{[700: 800)}\end{array}$ & $\begin{array}{c}(9) \\
{[800: 900)}\end{array}$ \\
\hline EM*Post 2008 & $\begin{array}{l}-0.026 \\
(0.049)\end{array}$ & $\begin{array}{l}-0.099 \\
(0.061)\end{array}$ & $\begin{array}{l}-0.015 \\
(0.028)\end{array}$ & $\begin{array}{r}0.009 \\
(0.033)\end{array}$ & $\begin{array}{l}-0.005 \\
(0.023)\end{array}$ & $\begin{array}{l}0.096 \text { *** } \\
(0.029)\end{array}$ & $\begin{array}{r}0.006 \\
(0.020)\end{array}$ & $\begin{array}{r}0.034 \\
(0.022)\end{array}$ & $\begin{array}{r}0.004 \\
(0.011)\end{array}$ \\
\hline EM*U.S. Treasury Basis & $\begin{array}{l}-0.128 * \\
(0.068)\end{array}$ & $\begin{array}{r}-0.020 \\
(0.069)\end{array}$ & $\begin{array}{r}0.058 \\
(0.058)\end{array}$ & $\begin{array}{c}0.103 \text { ** } \\
(0.0411)\end{array}$ & $\begin{array}{l}-0.021 \\
(0.030)\end{array}$ & $\begin{array}{r}0.029 \\
(0.037)\end{array}$ & $\begin{array}{r}0.005 \\
(0.025)\end{array}$ & $\begin{array}{l}-0.017 \text { ** } \\
(0.008)\end{array}$ & $\begin{array}{l}-0.010 \\
(0.017)\end{array}$ \\
\hline $\begin{array}{l}\text { EM*Post } 2008^{*} \text { U.S. } \\
\text { Treasury Basis }\end{array}$ & $\begin{array}{l}-0.284 * \\
(0.158)\end{array}$ & $\begin{array}{r}-0.175 \\
(0.120)\end{array}$ & $\begin{array}{r}0.116 \\
(0.113)\end{array}$ & $\begin{array}{r}-0.020 \\
(0.097)\end{array}$ & $\begin{array}{r}0.100 \\
(0.075)\end{array}$ & $\begin{array}{r}0.142 \\
(0.104)\end{array}$ & $\begin{array}{r}-0.068 \\
(0.071)\end{array}$ & $\begin{array}{l}0.178^{* * *} \\
(0.050)\end{array}$ & $\begin{array}{r}0.041 \\
(0.031)\end{array}$ \\
\hline Bond Controls & Yes & Yes & Yes & Yes & Yes & Yes & Yes & Yes & Yes \\
\hline Firm FE & Yes & Yes & Yes & Yes & Yes & Yes & Yes & Yes & Yes \\
\hline Industry-Year FE & Yes & Yes & Yes & Yes & Yes & Yes & Yes & Yes & Yes \\
\hline Quarter-Year FE & Yes & Yes & Yes & Yes & Yes & Yes & Yes & Yes & Yes \\
\hline Mean Probability & 0.367 & 0.170 & 0.125 & 0.0876 & 0.0469 & 0.101 & 0.0296 & 0.0506 & 0.0157 \\
\hline Number of Countries & 68 & 68 & 68 & 68 & 68 & 68 & 68 & 68 & 68 \\
\hline Number of Observations & 17,147 & 17,147 & 17,147 & 17,147 & 17,147 & 17,147 & 17,147 & 17,147 & 17,147 \\
\hline $\mathrm{R}^{2}$ & 0.572 & 0.369 & 0.390 & 0.432 & 0.450 & 0.410 & 0.435 & 0.380 & 0.457 \\
\hline
\end{tabular}




\section{Appendix Table 9 \\ Unconditional Probabilities of Issuing a Bond of Different Sizes}

This table reports difference-in-difference regressions of the change in the probability of issuing an international U.S. dollardenominated bond of a certain size in millions of U.S. dollars, pre and post 2008, for firms in emerging markets (EM) relative to the same change for investment grade firms in developed markets, during the 2000-2016 period. The analysis is restricted to positive and zero bond issuance observations. Columns 1-9 report the regressions for the bond issuance dummy of each size bucket on the interaction of the post 2008 dummy (equal to one for 2009-2016) with the emerging market dummy. All regressions include country, industry, and quarter-year fixed effects. Standard errors are clustered at the country and quarter-year levels. *, **, and *** indicate statistical significance at the $10 \%, 5 \%$, and $1 \%$ levels, respectively.

Dependent Variable: Dummy $=1$ if Issuance $=[X: X+100)$

\begin{tabular}{|c|c|c|c|c|c|c|c|c|c|}
\hline & \multicolumn{9}{|c|}{ Unconditional Probability of Issuing Debt of a Certain Amount } \\
\hline & $(1)$ & $(2)$ & (3) & (4) & (5) & $(6)$ & $(7)$ & $(8)$ & $(9)$ \\
\hline & {$[0: 100)$} & {$[100: 200)$} & [200:300) & {$[300: 400)$} & {$[400: 500)$} & {$[500: 600)$} & {$[600: 700)$} & [700:800) & {$[800: 900)$} \\
\hline \multirow[t]{2}{*}{ EM*Post 2008} & -0.064 & $-0.070 * *$ & -0.014 & $0.030 * *$ & 0.012 & $0.079 * * *$ & -0.002 & 0.016 & 0.010 \\
\hline & $(0.045)$ & $(0.027)$ & $(0.017)$ & $(0.014)$ & $(0.014)$ & $(0.020)$ & $(0.008)$ & $(0.010)$ & $(0.008)$ \\
\hline Country FE & Yes & Yes & Yes & Yes & Yes & Yes & Yes & Yes & Yes \\
\hline Industry FE & Yes & Yes & Yes & Yes & Yes & Yes & Yes & Yes & Yes \\
\hline Quarter-Year FE & Yes & Yes & Yes & Yes & Yes & Yes & Yes & Yes & Yes \\
\hline Number of Countries & 68 & 68 & 68 & 68 & 68 & 68 & 68 & 68 & 68 \\
\hline Number of Observations & 22,095 & 22,095 & 22,095 & 22,095 & 22,095 & 22,095 & 22,095 & 22,095 & 22,095 \\
\hline $\mathrm{R}^{2}$ & 0.170 & 0.0736 & 0.0459 & 0.0517 & 0.0365 & 0.0485 & 0.0312 & 0.0353 & 0.0233 \\
\hline
\end{tabular}




\section{Appendix Table 10 \\ Frequency of Bond Issuances}

This table reports the mean number of issuances and the duration between issuances for international U.S. dollar-denominated bonds of any size, with face values below $\$ 300$ million (0:300), between $\$ 300$ and $\$ 500$ million [300:500), and equal to or above $\$ 500$ million [500:1,000), by firms in emerging markets and investment grade firms in developed markets during 2000-2016. The analysis is restricted to firms that issued the relevant type of bond at least once during the sample period. Panel A reports the number of issuances per year as follows: (1) the total number of bonds issued are summed per firm-year observation, (2) the mean number of issuances are then computed per firm, (3) the mean firm is computed. Panel B reports the number of years between bond issuances on average. The values are computed as one over the respective values in Panel A.

Panel A. Number of Issuances per Year

\begin{tabular}{lccc}
\hline & Emerging Markets & & Developed Markets \\
\cline { 2 - 2 } Any Bucket Size & 0.145 & 0.293 \\
$(0: 300)$ & 0.128 & 0.288 \\
{$[300: 500)$} & 0.086 & 0.135 \\
{$[500: 1,000)$} & 0.113 & 0.174 \\
\hline \multicolumn{3}{c}{ Panel B. Years Between Issuances } & \\
\hline Any Bucket Size & Emerging Markets & Developed Markets \\
\cline { 2 - 3 }$(0: 300)$ & 6.898 & 3.411 \\
{$[300: 500)$} & 7.837 & 3.470 \\
{$[500: 1,000)$} & 11.669 & 7.389 \\
\hline
\end{tabular}

